\title{
16. BENTHIC FORAMINIFERAL STRATIGRAPHY AND PALEOENVIRONMENTS OFF PERU, LEG 112 1
}

\author{
Johanna M. Resig ${ }^{2}$
}

\begin{abstract}
Stratigraphic assemblages of Quaternary through early Eocene benthic foraminifers were recovered among 10 Peru margin drill sites. Various hiatuses and intervals barren in foraminifers characterize the sections, but numerous samples contain abundant, well-preserved benthic foraminifers.

Bathymetry of the extant species and California-based estimates of the paleobathymetry of the extinct species permit recognition of Quaternary sea-level fluctuations between shelf and upper bathyal depths that produced vertical migrations of oxygenated and low-oxygen habitats at the six shallow sites. Assemblages from lower-slope sites at about $9^{\circ}$ and $11^{\circ} \mathrm{S}$ indicate a general subsidence of the continental margin from shelf or upper bathyal depths in Eocene time to the present lower bathyal depths. Data from $11^{\circ} \mathrm{S}$ suggest a major part of this subsidence occurred in late Oligocene to early Miocene time. Downslope-transported shelf specimens, particularly the small biserial species, Bolivina costata and B. vaughani, are major contributors to these lower bathyal assemblages from the middle Miocene through Quaternary time.
\end{abstract}

\section{INTRODUCTION}

\section{Scope of Research}

Water masses, currents, changes in eustatic sea level, upwelling with consequent high primary productivity, low oxygen, diagenesis, phosphatization, downslope transport, and vertical tectonic displacement are the primary forces that affect the composition of modern and fossil benthic foraminiferal assemblages. Leg 112 Sites 679 through 688 were drilled in three transects off Peru (Fig. 1) to investigate the effect of these forces on the substance and configuration of the continental margin in historical perspective. In this research, foraminifers are principally indicators of paleobathymetry and oxygen levels; although stratigraphic assemblages are recognized, resolution is low relative to diatom and nannofossil stratigraphies (Schrader, Martini, this volume), which form the basis of ordering events for this study.

These drill sites fall into shallow- (150 to $450 \mathrm{~m}$ ) and deep-water ( 3000 to $5000 \mathrm{~m})$ groupings. Shallow sites (679, $680,681,684,686$, and 687 ) provide a record of upwelling and low-oxygen bottom conditions, as well as changes in sea level; deep sites $(682,683,685$, and 688$)$ record tectonic development of the margin. Because different assemblages of benthic foraminifers characterize the shallow- vs. deep-water sites and because of the different kinds of information derived from the two groupings, they are handled separately here. However, the results are combined ultimately to produce a summary of margin events along the three sampling transects at $9^{\circ}$, $11^{\circ}$, and $13^{\circ} \mathrm{S}$.

The research is introduced by a discussion of the modern environment in which the samples were taken, followed by a summary of previous studies of benthic foraminifers off western South America and other areas having similar assemblages. Benthic foraminifers off Peru are not well known and research about their distribution in other areas must be

\footnotetext{
${ }^{1}$ Suess, E., von Huene, R., et al., 1990. Proc. ODP, Sci. Results, 112: College Station, TX (Ocean Drilling Program).

2 Hawaii Institute of Geophysics and Department of Geology and Geophysics, University of Hawaii, Honolulu, HI 96822.
}

referenced for paleoecologic interpretation. Consequently, this research extends the known biogeographic and stratigraphic occurrence of several species of benthic foraminifers.

\section{Physical Environment}

\section{Biotopes and Overlying Water Masses and Currents}

Modern temperature profiles off Peru (National Oceanographic Data Center-NODC data), as well as water structure (Wyrtki, 1964, 1966, 1967) and benthic foraminiferal biotopes (Ingle et al., 1980), are shown in Figure 2 and summarized below.

The shelf biotope $(0-150 \mathrm{~m})$ lies beneath the northwardflowing Peru Current to mid-shelf depths and beneath the southward-flowing countercurrent farther seaward. The inner shelf subdivision $(0-50 \mathrm{~m})$ corresponds with the seasonal thermocline and also the maximum depth of the mixed layer. Biotas are subject to water temperatures of about $17^{\circ}$ to $24^{\circ} \mathrm{C}$. The outer shelf subdivision $(50-150 \mathrm{~m})$ corresponds with a permanent, poorly developed thermocline. Upwelling occurs when southeast trade winds blowing nearly parallel to the coast move surface water offshore and cold water rises from 50 to $350 \mathrm{~m}$ (mean depth of about $130 \mathrm{~m}$ ) on the outer shelf (Gunther, 1936). This flow reduces the surface-water temperature about $3^{\circ}$ or $4^{\circ} \mathrm{C}$ (e.g., Fahrbach et al., 1981). During Pleistocene glacial expansion, steepening of the temperature gradient in the subantarctic region may have increased transport volume and the northward extension of cooler waters in the Peru Current System (CLIMAP, 1976), substantially modifying conditions in the shelf biotope.

The upper bathyal biotope $(150-500 \mathrm{~m})$ lies beneath the southward-flowing countercurrent that transports equatorial subsurface water in which salinity is high and oxygen is low. Oxygen is further depleted in this biotope through decay of the organic products of upwelling. Temperature decreases from $15^{\circ}$ to $10^{\circ} \mathrm{C}$ from the top to the bottom of the biotope. All shallow sites of Leg 112 were drilled in this depth range.

The upper middle bathyal biotope $(500-1500 \mathrm{~m})$ is bathed in northward-flowing Antarctic Intermediate Water (AIW) in its upper half, which is also low in oxygen because of high surface productivity, and southward-flowing Pacific Deep 


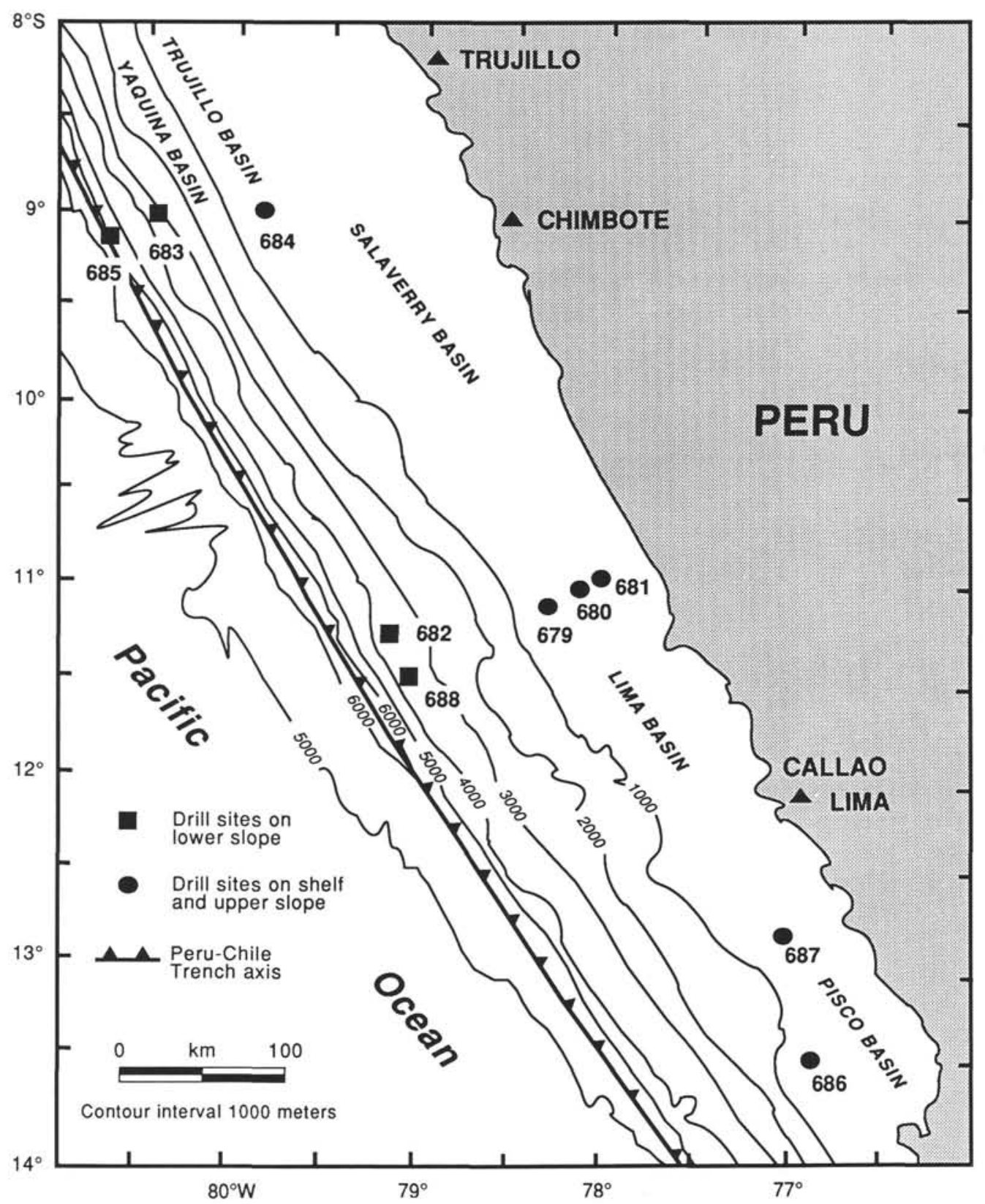

Figure 1. Site locations, Leg 112.

Water (PDW) with increasing oxygen content below. Bottom temperatures are about $8^{\circ}$ to $4^{\circ} \mathrm{C}$ from the top to the bottom of the biotope.

The lower middle bathyal biotope (1500-2000 m) and lower bathyal biotope (2000-4000 m) lie under PDW and Antarctic Bottom Water (AABW). The boundary between these two water masses occurs at approximately $3300 \mathrm{~m}$, the approximate depth of the lysocline (Berger, 1970). Physical conditions are uniform throughout. Three of the deep sites were drilled into this unit.

The abyssal biotope $(4000-6000 \mathrm{~m})$ is under AABW and beneath the carbonate compensation depth (CCD) so that only agglutinated assemblages live there (Resig, 1981). The environment is uniformly cold $\left(\sim 2^{\circ} \mathrm{C}\right)$. One deep site was drilled into this biotope.

\section{Primary Productivity and the Oxygen-Minimum Zone}

Phytoplankton productivity, monitored seasonally over a $10-\mathrm{yr}$ period (Rojas de Mendiola, 1981), shows an average Spring concentration in excess of $1 \times 10^{5}$ cells per liter in a band extending about $225 \mathrm{~km}$ from the coast of Peru (Fig. 3). Within this band, highest productivity exceeds $5 \times 10^{5}$ cells per liter in the Pisco Basin area, an upwelling center within about $115 \mathrm{~km}$ of shore. The recurrent high productivity contributes in excess of $50 \times 10^{6}$ diatom valves to each gram of sediment underlying the most productive areas and affects deposition on the seafloor to a water depth of $3600 \mathrm{~m}$ (Schuette and Schrader, 1981). The nearshore regions of high productivity each bear distinctive diatom floras that are preserved in the fossil record (Schrader, this volume). 


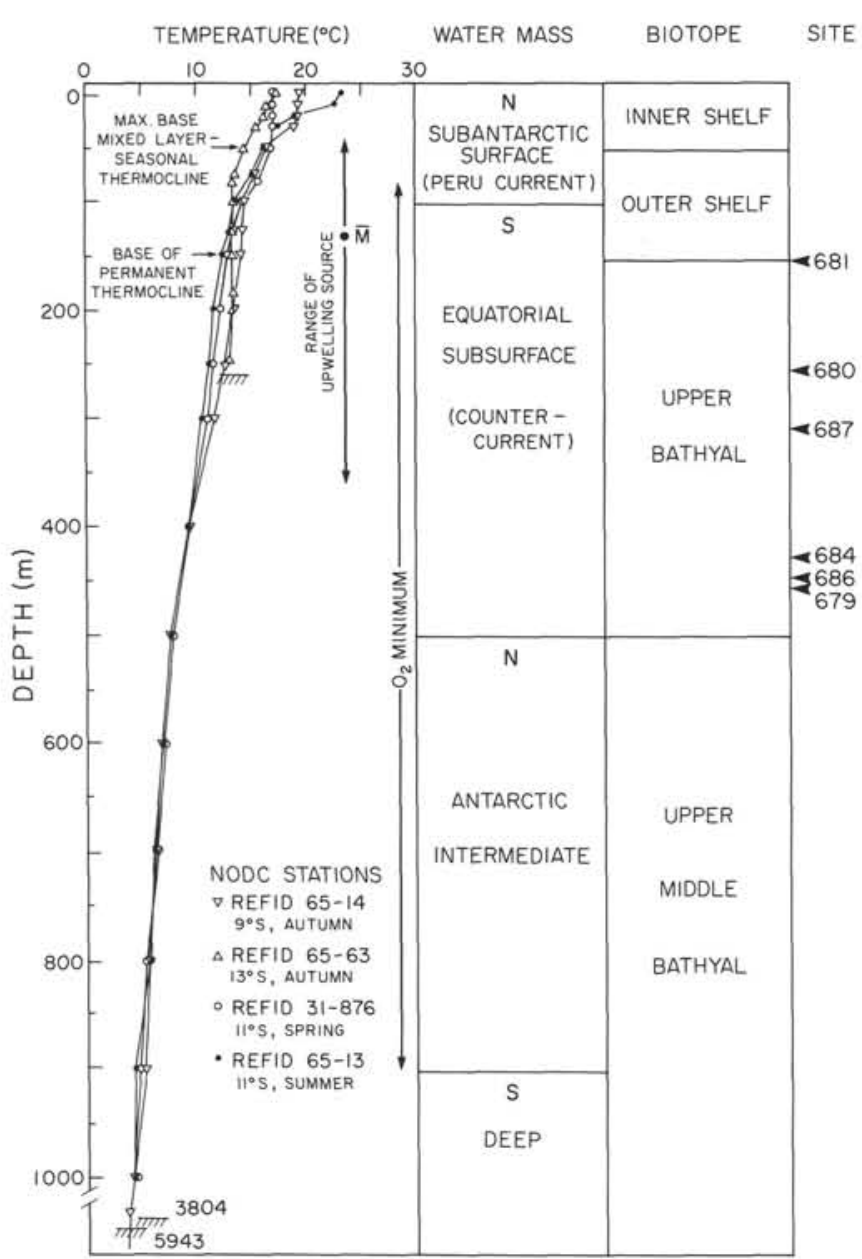

Figure 2. Bathymetric distribution of shallow sites in relation to modern temperatures, water masses, and benthic foraminiferal biotopes off Peru.

Oxidation of organic matter depletes oxygen on the seafloor beneath the highly productive areas over a depth range of about 100 to $900 \mathrm{~m}$ in the study area (Fig. 4). Low oxygen effectively discourages macroinvertebrates, leading to laminated diatomaceous sediments; however, certain foraminifers are adapted to that habitat (summary in Ingle and Keller, 1980) and occur there abundantly. These sediments contain up to $6.9 \%$ organic carbon (Rosato et al., 1975), which might form part of the food supply. All the shallow ODP sampling sites were drilled in the core of the oxygen-minimum zone $(<0.2$ $\mathrm{mL} / \mathrm{L}$ ), where the effect of the influx of decaying organic matter is fortified by the initial low-oxygen content of the water of the countercurrent.

Another consequence of the low-oxygen condition is the deposition of phosphorite. A mat of sulfur bacteria covers the low-oxygen seafloor (Rowe, 1981). The oxidation of organic matter during sulfate reduction by these bacteria releases phosphate to the interstitial fluids (Burnett, 1977). Phosphorite is deposited in the low-oxygen environment when calcite from the dissolution of foraminifers combines with the phosphate at $\mathrm{pH} 7.0$ to 7.8 (Brooks et al., 1968). Whereas foraminifers are often destroyed in the phosphatization process, in some instances phosphatized remains of foraminifers give evidence of the former bottom assemblage (Manheim et al., 1975).

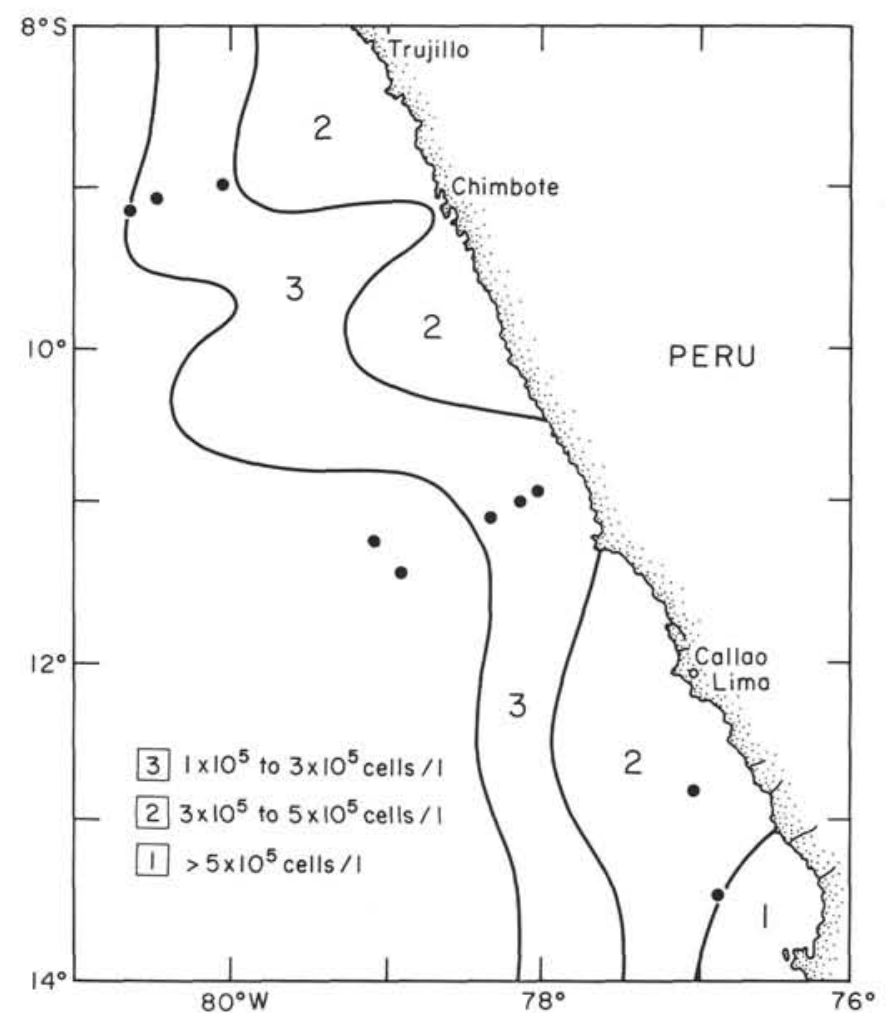

Figure 3. Primary productivity of phytoplankton sampled at $10 \mathrm{~m}$ water depth in the study area, Spring 1961 through 1970 (after Rojas de Mendiola, 1981). ODP sites as in Figure 1.

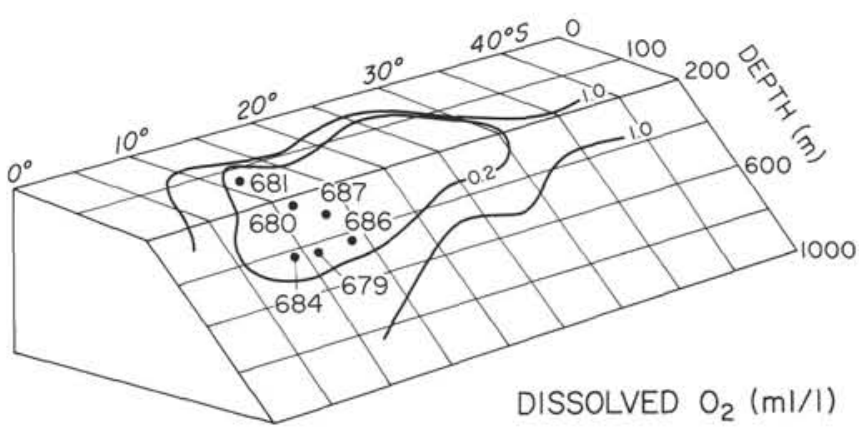

Figure 4. Location of sites in relation to the oxygen-minium zone. Bottom water dissolved oxygen less than $1.0 \mathrm{~mL} / \mathrm{L}$, after Burnett et al. (1980). Phosphorite deposition occurs between the $1.0 \mathrm{~mL} / \mathrm{L}$ contour and the anaerobic core of the oxygen-minimum zone.

\section{Sediment Textures}

On the Peruvian margin, brownish green to gray green diatomaceous mud and sand or larger-grained sediments are common (reviewed by Rosato et al., 1975), sometimes alternating temporally, as seen in cores (Zen, 1959). Although the median grain size tends to decrease seaward, grain size, sorting, and composition are variable and reflect heterogeneous sources, including Andean detritus with abundant quartz, volcanic glass shards, shells that commonly occur near the shore, and authigenic glauconite and phosphorite. Rates of accumulation of these margin sediments range from 10 to $30 \mathrm{~mm} / 10^{3} \mathrm{yr}$ (Rosato et al., 1975).

Sediment distribution patterns are further complicated through redeposition of grains following downslope transport. Although detrital grains are difficult to trace, the foraminiferal 
distribution data of Bandy and Rodolfo (1964) and Resig (1981) revealed that this process is active on the Peru margin. Recently, using SeaMARC side-scanning sonar, Coulbourn and Moberly (1988) mapped a distributary system for turbidites entering the Peru-Chile Trench from the margin near the Arica Bight.

\section{Background Studies}

In summarizing Holocene foraminiferal distribution along the South American coast, Boltovskoy (1976) designated the assemblages of the study area as only partially or poorly known and assigned the principally shelf species known at that time to a temperate Peruvian subprovince. Subsequent research has shown that many of the characteristic outer-shelf and upper-slope species extend southward along the Chilean coast at least as far as Valparaiso (Ingle et al., 1980) and northward to Central America (Smith, 1964). Deeper water species are even more widely distributed.

Depth distribution of Holocene benthic foraminifers in the study area was shown in a single composite profile by Resig (1981) and in composite profiles of Peru-Chile data by Bandy and Rodolfo (1964). These data, plus depth profiles of species off Chile in shelf (Boltovskoy and Theyer, 1970) and outer shelf to abyssal habitats (Ingle et al., 1980) and off El Salvador (Smith, 1964), provide the basic information for determining paleobathymetry based on modern species. Ingle (1980) interpreted paleobathymetry for extinct Paleogene and Neogene species from California stratigraphic sections that contain some of the species found off Peru.

Living specimens from the Peruvian oxygen-minimum zone (Phleger and Soutar, 1973; Khusid, 1984) consist principally of bolivinids, with one strongly dominant species in standing crops that exceed 1200 specimens $/ 20 \mathrm{~cm}^{2}$ of surface sediment (Phleger and Soutar, 1973). An assemblage change toward greater diversity, including an increase in abundance of Cancris and Epistominella, as well as larger, more robust species, occurs in the lower part of the oxygen-minimum zone (Khusid, 1984).

\section{ANALYTICAL METHODS}

\section{Sample Preparation}

The core-catcher samples, which are variable in volume, were processed aboard ship directly after or within $12 \mathrm{hr}$ of core recovery, whereas the $10-$ or $20-\mathrm{cm}^{3}$ samples from one or more sections per core were sealed in plastic until immediately before they were processed in the shore-based laboratory, 8 months after recovery. It was noted subsequently that many of the samples processed onshore contained large crystals of gypsum, whereas these were rare in the corecatcher samples. In view of the hypersaline brine in pore waters of the study area (Kastner, this volume), it is likely that this precipitation of gypsum resulted from dehydration of the samples, in spite of their encasement in plastic. Zen (1959) reported similar occurrences of halite and gypsum in cores from the Peruvian margin, which he attributed to dehydration.

Semiconsolidated and lithified sediment was crushed to pellet-size particles and soaked in water before sieving, but no chemicals were used to disaggregate the material. All samples were wet-sieved on a screen with $62 \mu \mathrm{m}$ openings, and the dried sand fraction was divided by an OTTO-style microsplitter until roughly 200 to 500 benthic specimens remained. These were identified and counted and their percentage frequencies entered in data tables. Census data for those samples containing fewer than 100 specimens were not entered in the tables, as the results were considered biased by preservation. Poor preservation of tests is noted in the text.

\section{Taxonomy}

Where possible, taxonomy follows the generic classification adopted by Loeblich and Tappan (1987). In some instances, this has resulted in nomenclature differing from that used in Suess, von Huene, et al. (1988). Species that have undergone taxonomic changes are listed in the Appendix. Illustrated publications that were used extensively for benthic species identifications include those of the following researchers, grouped here according to age of study material: Quaternary (d'Orbigny, 1839; Natland, 1950; Uchio, 1960; Bandy, 1961; Smith, 1964; Boltovskoy and Theyer, 1970; McCulloch, 1977; Ingle et al., 1980; and Resig, 1981), Neogene (Kleinpell, 1938; Coryell and Mossman, 1942; Cushman and Gray, 1946; Cushman and Stevenson, 1948; Renz, 1948; Parker, 1964; Kleinpell, 1980; Haller, 1980), and Paleogene (Cushman and Stone, 1947; Stainforth, 1948; Cushman and Stone, 1949a and 1949b; Todd and Kniker, 1952; and Hofker, 1956).

\section{Paleobathymetry}

Species depth distribution data from various sources are used here to evaluate paleobathymetry (Fig. 5). Water depth curves are reconstructed from these data on the basis of the average depth or the tops or bottoms of biotopes, depending on whether species representation is indicative of boundary conditions, i.e., transition of one biotope to another. Interpretation of the paleobathymetry of the shallow sites relies further on modern species distribution in the area, as determined from near-surface samples of the Leg 112 cores combined with other core-top data from the area (Resig, 1981) (Fig. 6). Three principal assemblages occur over the depth interval of these samples, each characterized by well-defined species. Bolivina costata dominates the mid- to outer-shelf biotope to about $110 \mathrm{~m}$ and becomes rare below $150 \mathrm{~m}$. Bolivinellina humilis composes more than one-half of the benthic foraminifers on the outermost shelf and in the upper bathyal biotope to a depth of about $300 \mathrm{~m}$; this species becomes rare below about $500 \mathrm{~m}$. This assemblage, which occurs in laminated diatomaceous mud, is coincident with upwelling and benthic oxygen-minimum conditions. A third assemblage, showing less species dominance but in which Bolivina plicata and Angulogerina carinata are conspicuous components, occurs from about 300 to $630 \mathrm{~m}$ or more. (Data from the 1964 report of Bandy and Rodolfo suggest an assemblage change by $800 \mathrm{~m}$.) This third assemblage comprises foraminiferal sand layers that result from periodic current activity in the lower part of the countercurrent regime.

In addition to the in-situ assemblages, downslope displacement of individual species is recognized through occurrences that are apart from their distributional continuity and, for the most part, their maximum frequency. Turbidite deposits are identified through abrupt stratigraphic assemblage changes, combined with sedimentological evidence.

\section{UPPER-SLOPE SITES}

Percentage frequencies of species occurring at the six shallow sites (Tables 1 through 6) reveal intersite differences in species composition and representation, according to water depth and temporal assemblage changes. These sites are discussed in order of descending water depth.

\section{Hole 681A (151 m, Lima Basin)}

Quaternary benthic foraminifers recovered at this site are predominantly mid- to outer-shelf assemblages in which $\mathrm{Bo}$ livina costata, Nonionella auris, and Buliminella elegantissima are the dominant species (Fig. 7). High frequencies of Bolivinellina humilis near the surface and in some deeper 
BENTHIC FORAMINIFERAL STRATIGRAPHY

EXTANT SPECIES

Nonionella miocenica

Nonionoides basispinatus

Buliminella elegantissima limbosa

Buliminella elegantissima

Zeaflorilus chiliensis

Bolivina costata

Buccella spp.

Nonionella auris

Bolivinellina pacifica

Uvigerina semitrigona

Hanzawaia nitidula

Angulogerina carinata

A. carinata bradyana

Bolivina plicata

Bulimina puichella

Bolivina vaughani

Cancris inflatus

Buliminella curta

Bolivinellina humilis

Brizalina interjuncta

B. interjuncta bicostata

Pseudoparella subperuviana

Cassidulina detierraensis

Cassidulina auka

Globobulimina ovula

Suggrunda eckisi

Buliminella subfusiformis

Uvigerina striata

Brizalina spissa

Bolivinita minuta

Takayanagia delicata

Uvigerina peregrina dir.

Brizalina pseudobeyrichi

Hansenisca altiformis

Bulimina rostrata

Melonis pompilioides

Uvigerina senticosa

EXTINCT SPECIES

Brizalina jacksonensis

Globocassidulina globosa

Holmanella valmonteensis

Spiroplectammina gryzbowski

Valvulineria depressa

Bolivina advena

Bolivinellina californica

Bolivinellina cuneata

Bulimina pupoides

Uvigerina gallowayi

Valvulineria californica

Ambitropus thalmanni

Bolivina granti

Bolivinellina foraminata

Bolivinellina girardensis

Bolivinellina goudkoffi

Brizalina imbricata

Brizalina pisciformis

Bulimina alligata

Bulimina jacksonensis

Siphogenerina spp.

Uvigerina hispidocostata

Cibicidoides grimsdale

Cibicidoides perlucidus

Cyclammina spp.

Hansenisca multilocula

Plectofrondicularia spp.

Stilostomella spp.

Bathysiphon spp.

Nuttallides truempyi

Plectofrondicularia californica

Pleurostomella spp.

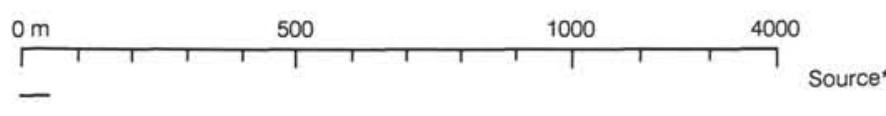

2
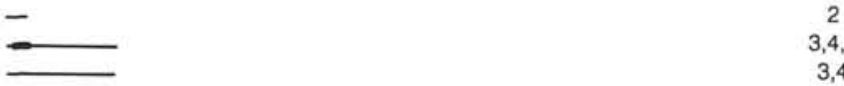

3,4

1,2

3

3

2

3

8
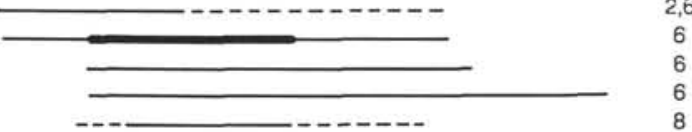

$--\cdots--$

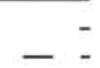

6

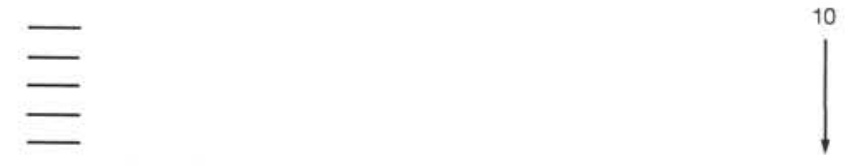

*REFS.1) Resig (1981), 2) Cushman and McCulloch (1940,-42,-48),

3) Boltovskoy and Theyer (1970), 4) Bandy (1961), 5) Uchio (1960),

6) Ingle, Keller, and Kolpack (1980), 7) McCulloch (1977),

8) Smith (1963), 9) Smith (1964), 10) Ingle (1980)

Figure 5. Reported depth ranges of some Peru margin benthic foraminiferal species. 


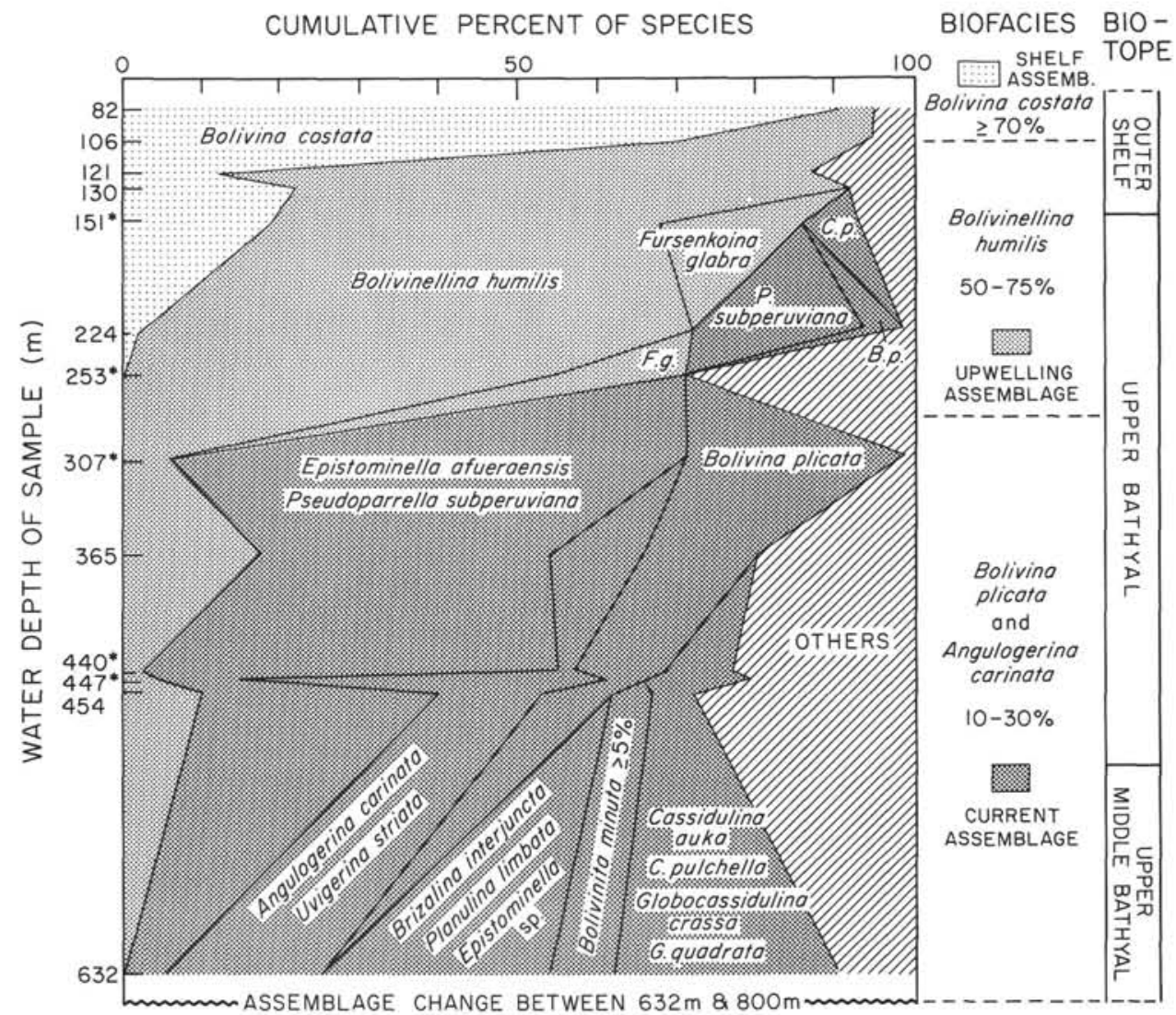

Figure 6. Bathymetry of modern species in the study area. Samples from Leg $112\left(^{*}\right)$ and Resig (1981).

horizons indicate present and past intervals of low-oxygen conditions in the outermost shelf to upper bathyal environment.

The stratigraphic progression of assemblages shows fluctuations in sea level throughout the section, with the lowest stand at about $45 \mathrm{mbsf}$. This stand is characterized by a mid-shelf assemblage having high percentage of Buliminella elegantissima and B. elegantissima limbosa and a $5 \%$ to $6 \%$ occurrence of Buccella peruviana. The highest stands of sea level occur at about $30 \mathrm{mbsf}$ and in the upper $9 \mathrm{~m}$ of the section, as defined by high percentages of Bolivinellina humilis, which dominates outer-shelf to upper bathyal foraminiferal assemblages. Silty sand at the base of the section is mostly barren of foraminifers, except for two samples at about 160 and $170 \mathrm{mbsf}$ that contain shelf to upper bathyal species. Sample 112-681A-19X-CC (170 mbsf) contains 52\% B. humilis, which denotes deeper water than is indicated by the lithology of the sample, a gravelly deposit with sand. This sample is probably a shallow shelf deposit with reworked foraminifers. Ammobaculites sp., which is present at $4 \%$, occurs only in this sample and in the late Miocene shallowwater section of Site 679. The genus is a frequent inhabitant of brackish water environments (summarized by Boltovskoy and Wright, 1976). Its presence at Site 681 near the base of the cored section may result from shallow coastal conditions there, or to reworking, or both. Reworked Eocene/Oligocene diatoms occur in the sample (Schrader, this volume).

\section{Hole 680B (253 m, Lima Basin)}

Foraminiferal assemblages were recovered from the Quaternary section and from a single sample taken from near the top of the Pliocene section (Fig. 8). All other Pliocene sam- ples, as well as several from the lower Quaternary, were barren of foraminifers. Aside from two foraminiferal sand layers bearing mollusk fragments and an Angulogerina carinata-Uvigerina striata assemblage indicative of current-generated deposition in the lower upper bathyal countercurrent regime, the Quaternary assemblages are dominated by Bolivinellina humilis, deposited under upwelling, oxygen-minimum conditions. Variation in the proportion of components suggests changes in sea level. The late Pliocene assemblage with $33 \%$ Buliminella elegantissima is characteristic of the midshelf. The depth differential between this and subsequent deposits is too great to be accounted for by fluctuations in sea level alone. Therefore, subsidence of $100 \mathrm{~m}$ or more is indicated between the Pliocene and Quaternary deposition.

\section{Hole 687A (307 m, South Lima Basin)}

Assemblages in this hole are dominated by shelf species in the Pliocene and early Quaternary, with deposits as shallow as mid- to inner-shelf depths characterized by high percentages of Buliminella elegantissima and sandy, shell-bearing sediments (Fig. 9). The late Quaternary assemblages represent upwelling conditions in which upper bathyal low-oxygen substrates are dominated by Bolivinellina humilis and $B$. rankini. In this part of the section, some sandy turbidite layers contain shelf species. The most recent assemblage (Sample $112-687 \mathrm{~A}-1 \mathrm{H}-4,110-114)$ is dominated by Bolivina plicata and Epistominella afueraensis that occur in foraminiferal sands indicative of current-modified deposition.

The magnitude of the paleobathymetric increase from about $50 \mathrm{~m}$ to 250 or $300 \mathrm{~m}$ that occurs between the early and late Quaternary Cores 112-687A-8X and -7X is too large to be accounted for by fluctuations in sea level alone. Subsidence of 
Table 1. Percentage of species representation, Hole 679D (440 m).

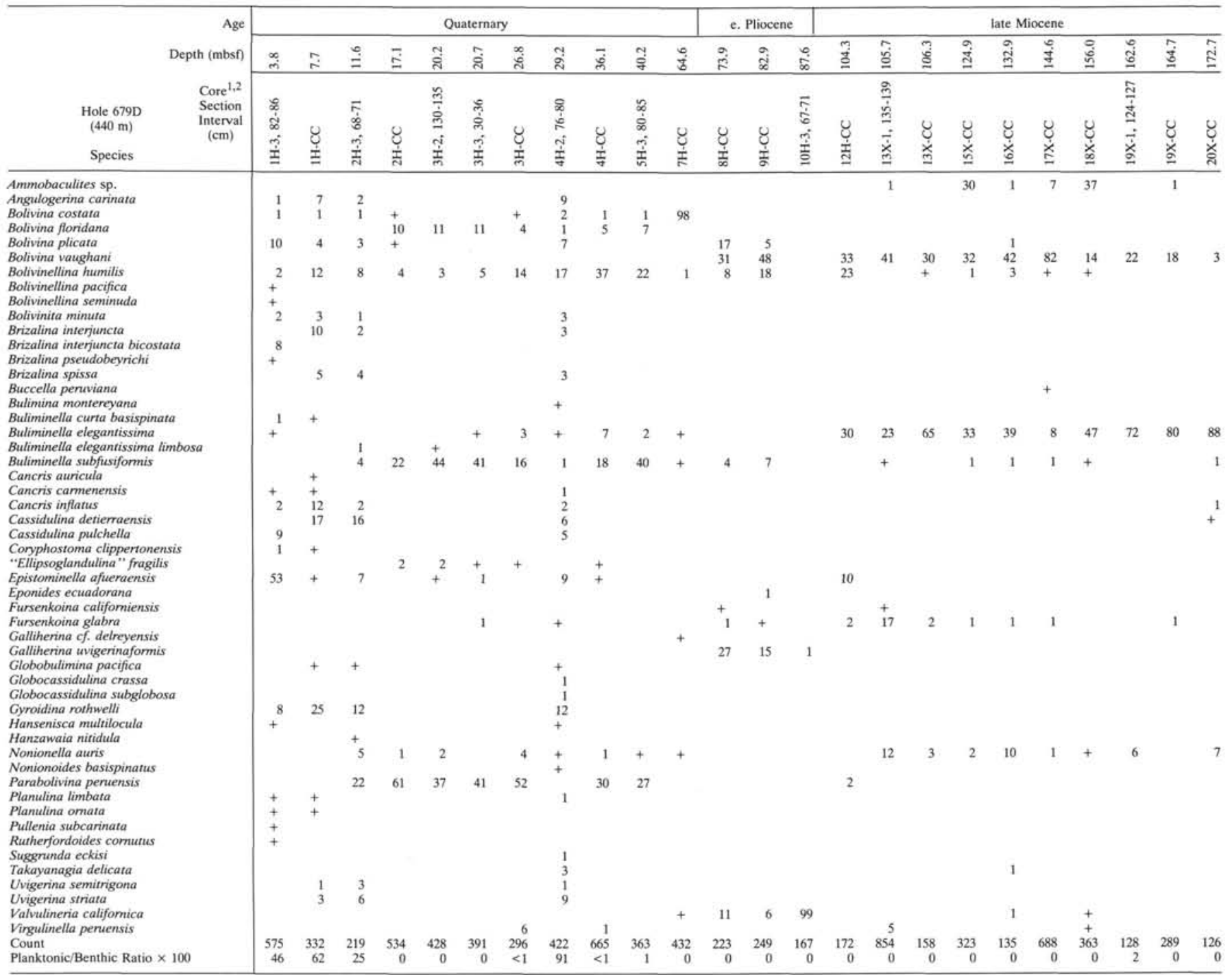

${ }^{1}$ Barren of foraminifers: $5 \mathrm{H}-\mathrm{CC} ; 6 \mathrm{H}-3,66-68 ; 6 \mathrm{H}-\mathrm{CC} ; 7 \mathrm{H}-3,78-80 ; 8 \mathrm{H}-3,66-70 ; 9 \mathrm{H}-3,66-69 ; 10 \mathrm{H}-\mathrm{CC} ; 11 \mathrm{H}-3,64-68 ; 14 \mathrm{X}-2,50-54 ; 15 \mathrm{X}-1,112-116 ; 18 \mathrm{X}-1,113-116 ; 20 \mathrm{X}-1,81-85 ; 21 \mathrm{X}-\mathrm{CC} ; 22 \mathrm{X}-\mathrm{CC} ; 24 \mathrm{X}-1,13-17$; ${ }^{2}$ Counts less than $100: 11 \mathrm{H}-\mathrm{CC} ; 14 \mathrm{X}-\mathrm{CC} ; 17 \mathrm{X}-1,91-95 ; 23 \mathrm{X}-\mathrm{CC}$.

at least $150 \mathrm{~m}$ or more must have occurred in the middle of the Quaternary section.

\section{Hole 684A (426 m, Trujillo Basin)}

The section at this site registers more disruption of habitats and stratigraphy than the previously discussed Lima Basin sections. The late Miocene assemblage with high percentages of Buliminella subfusiformis, Bolivina vaughani, and other bolivinids, combined with lesser percentages of Valvulineria cf. compressa and V. cf. depressa, represents a transitional outer-shelf to upper bathyal environment (Fig. 10). After an erosional event that produced a 5.4-m.y. hiatus (Schrader, Martini, this volume), deposition resumed in the middle Pliocene in an upper middle bathyal biotope characterized by Uvigerina peregrina, Cassidulina cushmani, Takayanagia delicata, and Epistominella smithi. This deposition was truncated by another hiatus (duration of about $2 \mathrm{~m}$.y.). The overlying late Quaternary deposits contain a current-dominated foraminiferal sand containing mollusk shells and an Angulogerina carinata-Uvigerina striata assemblage. This sand may have been deposited somewhat shallower than the present water depth because Bolivinita minuta is rare. The youngest Quaternary deposits at this site contain the upwelling-dominated, low-oxygen assemblage characterized by high percentages of Bolivinellina humilis. The change from current to upwelling-dominated regime, indicated by the assemblages, contrasts with the circulation pattern of the southern sites in approximately the same water depth, where the current-dominated assemblage occupies the uppermost layers. The difference in paleobathymetry between the late Miocene and the middle Pliocene deposition is too great to be attributed to changes in sea level, and the section was apparently down-dropped about $400 \mathrm{~m}$ during that interval. Habitat displacement across the mid-Pliocene to late Quaternary hiatus might be attributed, at least in part, to changes in sea level.

\section{Holes 679D and 679E (440 m, Lima Basin)}

Long stratigraphic intervals at this site were barren of benthic foraminifers (Fig. 11), which prevented continuity in the paleobathymetric interpretation. The oldest strata of the hole, Cores 112-679E-11X through -13X (340 to $360 \mathrm{mbsf}$ ) are 
Table 2. Percentage of species representation, Hole $680 \mathrm{~B}(253 \mathrm{~m})$.

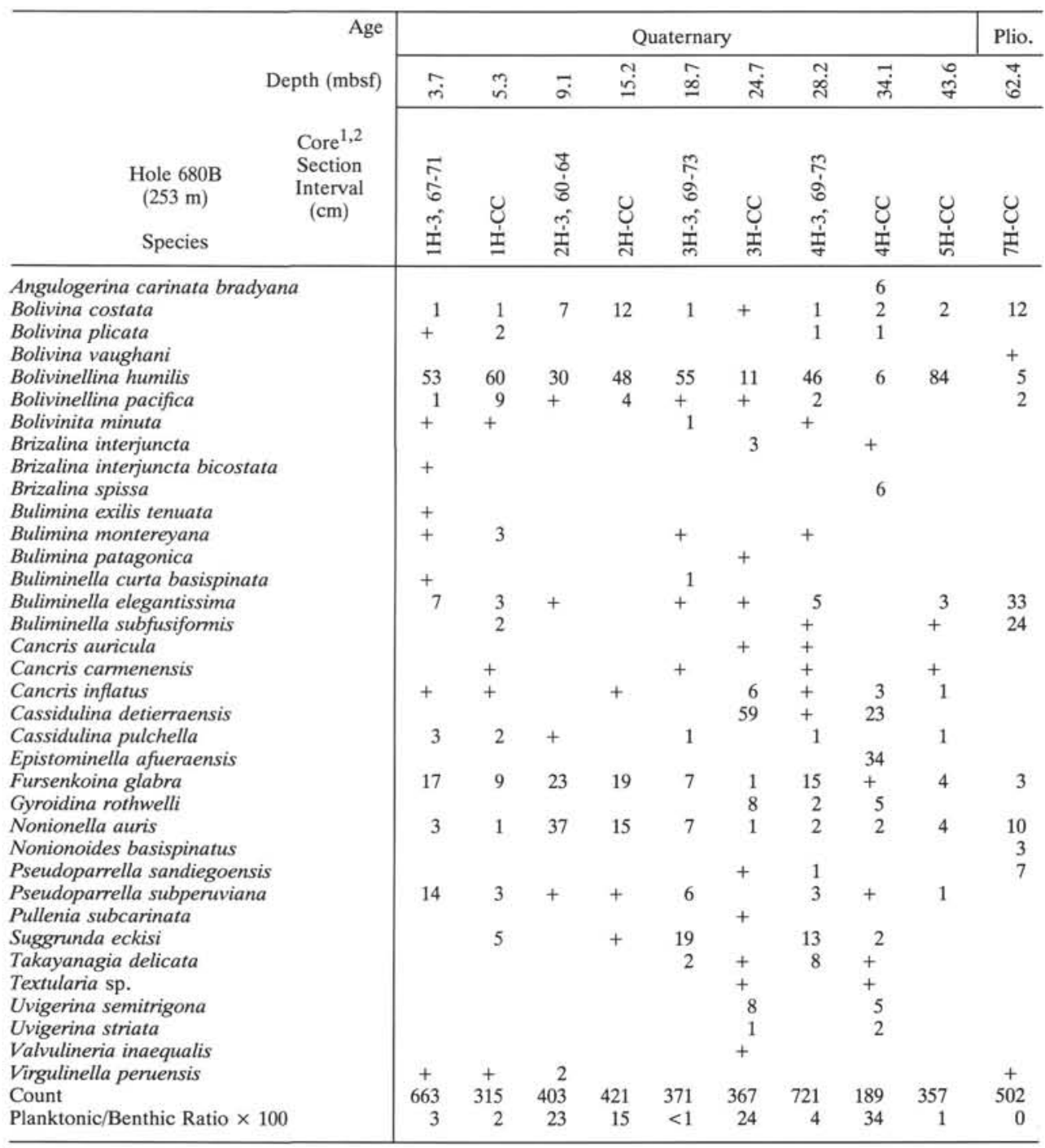

${ }^{1}$ Barren of foraminifers: $5 \mathrm{H}-3,10-14 ; 6 \mathrm{H}-3,58-62 ; 7 \mathrm{H}-3,37-41 ; 8 \mathrm{H}-5,43-47 ; 8 \mathrm{H}-\mathrm{CC} ; 9 \mathrm{H}-3,69-73 ; 9 \mathrm{H}-\mathrm{CC} ; 10 \mathrm{H}-4$, $55-58 ; 10 \mathrm{H}-\mathrm{CC} ; 11 \mathrm{H}-1,71-72 ; 11 \mathrm{H}-\mathrm{CC} ; 12 \mathrm{X}-\mathrm{CC} ; 14 \mathrm{X}-1,39-43 ; 14 \mathrm{X}-\mathrm{CC} ; 18 \mathrm{X}-\mathrm{CC} ; 19 \mathrm{X}-\mathrm{CC}$;
20X-CC; $21 \mathrm{X}-1,69-73 ; 21 \mathrm{X}-\mathrm{CC} ; 22 \mathrm{X}-\mathrm{CC}$.

${ }^{2}$ Counts less than 100: $6 \mathrm{H}-\mathrm{CC}$.

middle Miocene black shale containing Valvulineria $\mathrm{cf}$. depressa, Bolivina cf. costata, Bulimina sp., Brizalina sp., and Buliminella elegantissima, indicating an outer-shelf, low-oxygen environment. The next foraminifer-bearing strata occur in Cores 112-679D-15X through -20X (125 to $173 \mathrm{mbsf}$ ), are late Miocene in age, and contain high percentages of Buliminella elegantissima and Bolivina vaughani, indicating shelf depths. Following a hiatus at the top of the late Miocene, early Pliocene deposition shifted to an outermost shelf to uppermost bathyal environment, dominated by Valvulineria californica, Galliherina uvigerinaformis, and Bolivina vaughani. The next stratigraphically higher strata containing foraminifers are of Quaternary age, with upper bathyal assemblages showing fluctuations, current- and upwelling-dominated environments. This could be the result of eustatic fluctuations or shifting upwelling cells, or both. The youngest strata contain the current-influenced assemblage with Angulogerina carinata and Epistominella afueraensis, Bolivina plicata, and Uvigerina striata. The upwelling-controlled assemblage has Boliv- inellina humilis, Buliminella subfusiformis, and Parabolivina peruensis.

Subsidence of the site from shelf through the upper bathyal biotope occurred during the course of early Pliocene through Quaternary deposition.

\section{Hole 686A (447 m, Pisco Basin)}

Except for one deeper excursion, the Quaternary section (150 and $211 \mathrm{mbsf}$ ) of Site 686 was deposited on the shelf. The sediment consists of silt, sand, and shell debris, and the foraminiferal assemblage contains Buliminella elegantissima, Nonionella spp., Bolivina costata and Alexanderina viejoensis. Concurrent high frequencies of Bolivinellina humilis indicate low-oxygen conditions (Fig. 12). From 150 to $90 \mathrm{mbsf}$, an upper bathyal environment influenced by upwelling and lowoxygen substrate is indicated by high frequencies of Bolivinellina humilis and associated species. The stratigraphic section between 90 and 25 mbsf is mostly barren of benthic foraminifers, except for an interval between 75 and 60 mbsf that 
Table 3. Percentage of species representation, Hole 681A (151 m).

${ }^{1}$ Barren and ${ }^{2}$ Low count samples listed below. $+=$ less than $1 \%$

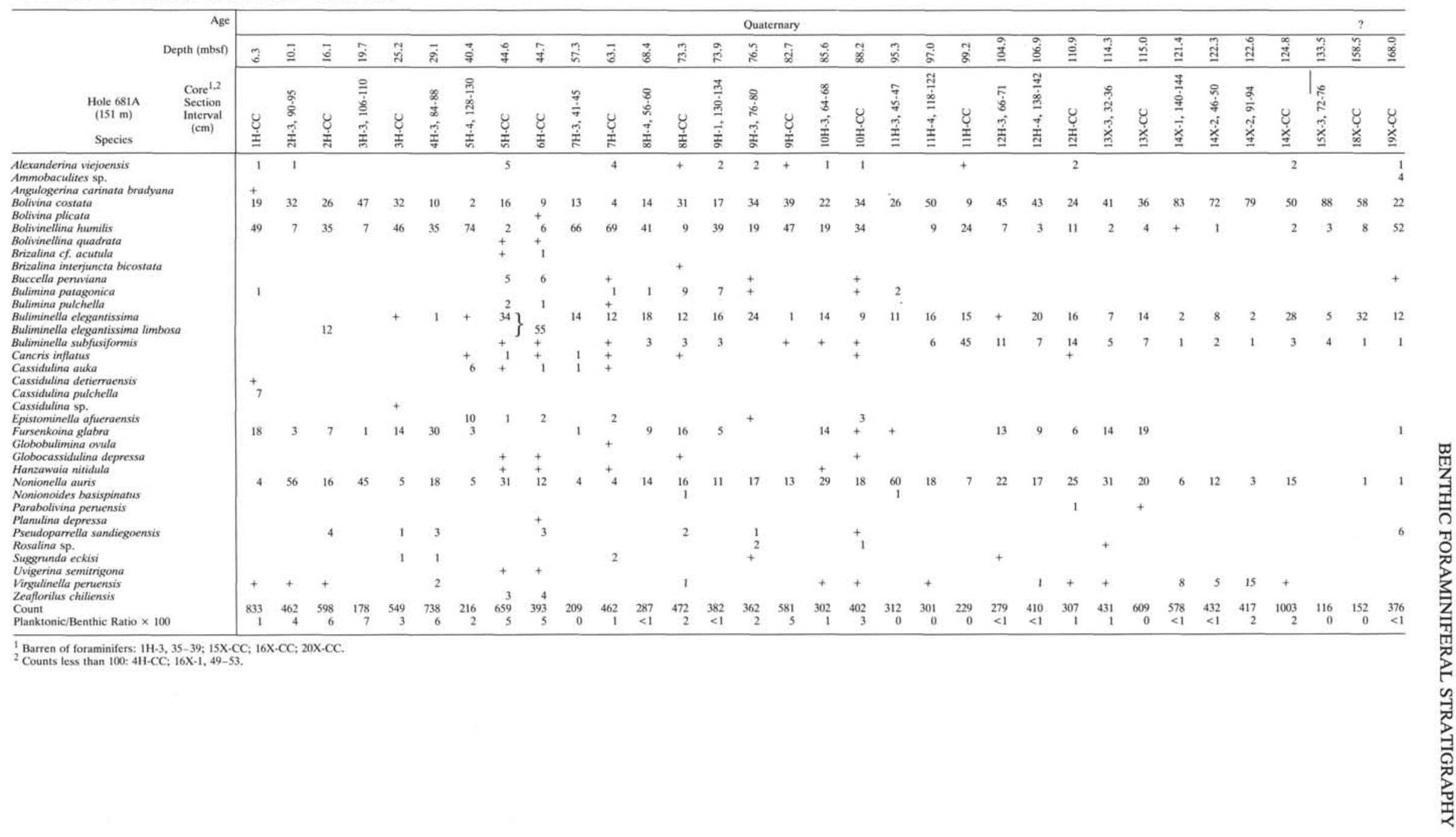


Table 4. Percentage of species representation, Hole 684A (426 m).

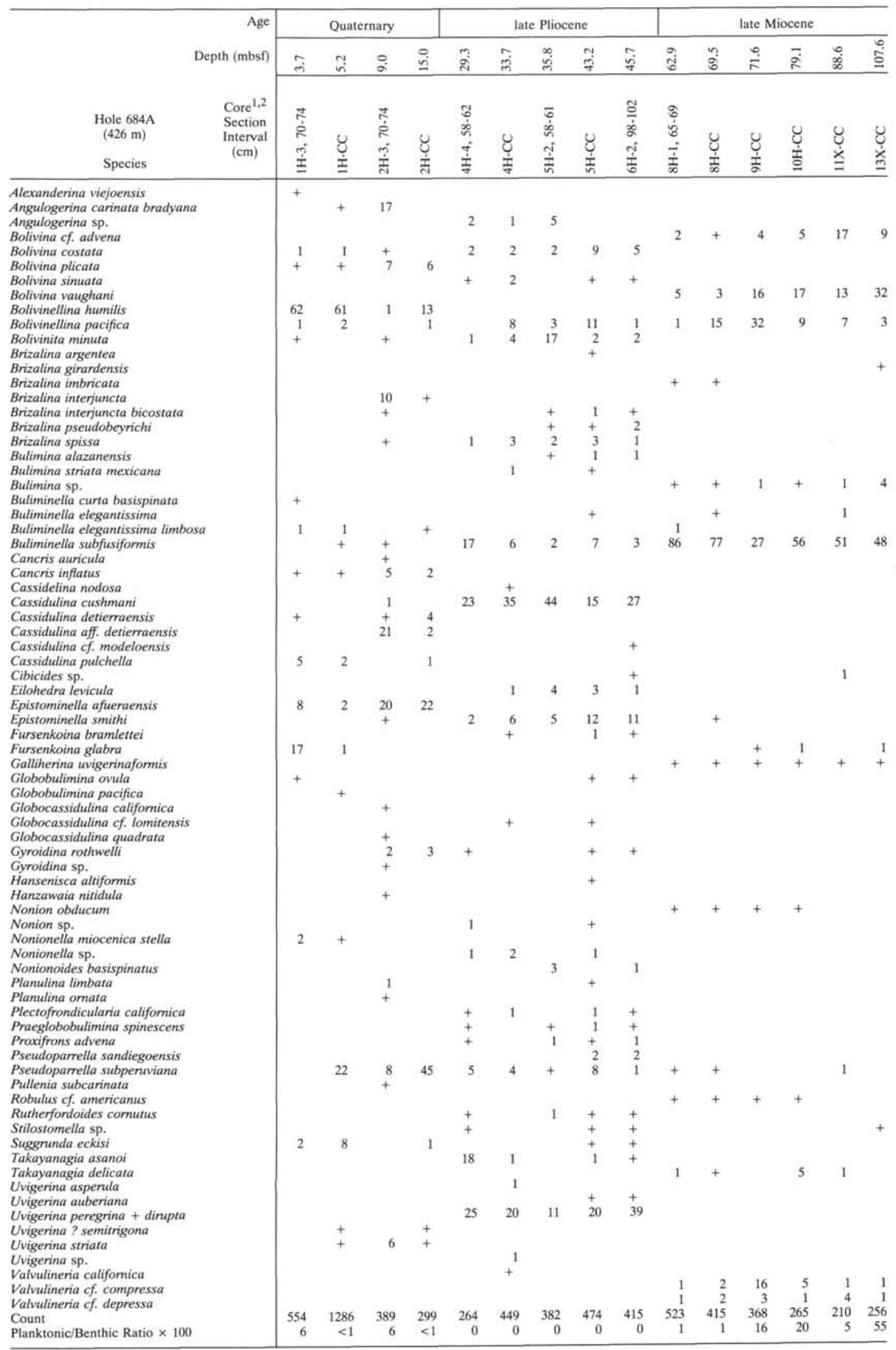

1 Barren of foraminifers: $-3 \mathrm{H}-3,74-78 \mathrm{~cm} ;-3 \mathrm{H}-\mathrm{CC} ; 6 \mathrm{H}-\mathrm{CC} ; 7 \mathrm{H}-1,77-81 \mathrm{~cm} ;-7 \mathrm{H}-\mathrm{CC}$.

${ }^{2}$ Downhole contamination: $-11 \mathrm{X}-\mathrm{CC} ;-12 \mathrm{X}-\mathrm{CC} ;-14 \mathrm{X}-\mathrm{CC}$ 
Table 5. Percentage of species representation, Hole 686A $(447 \mathrm{~m})$.

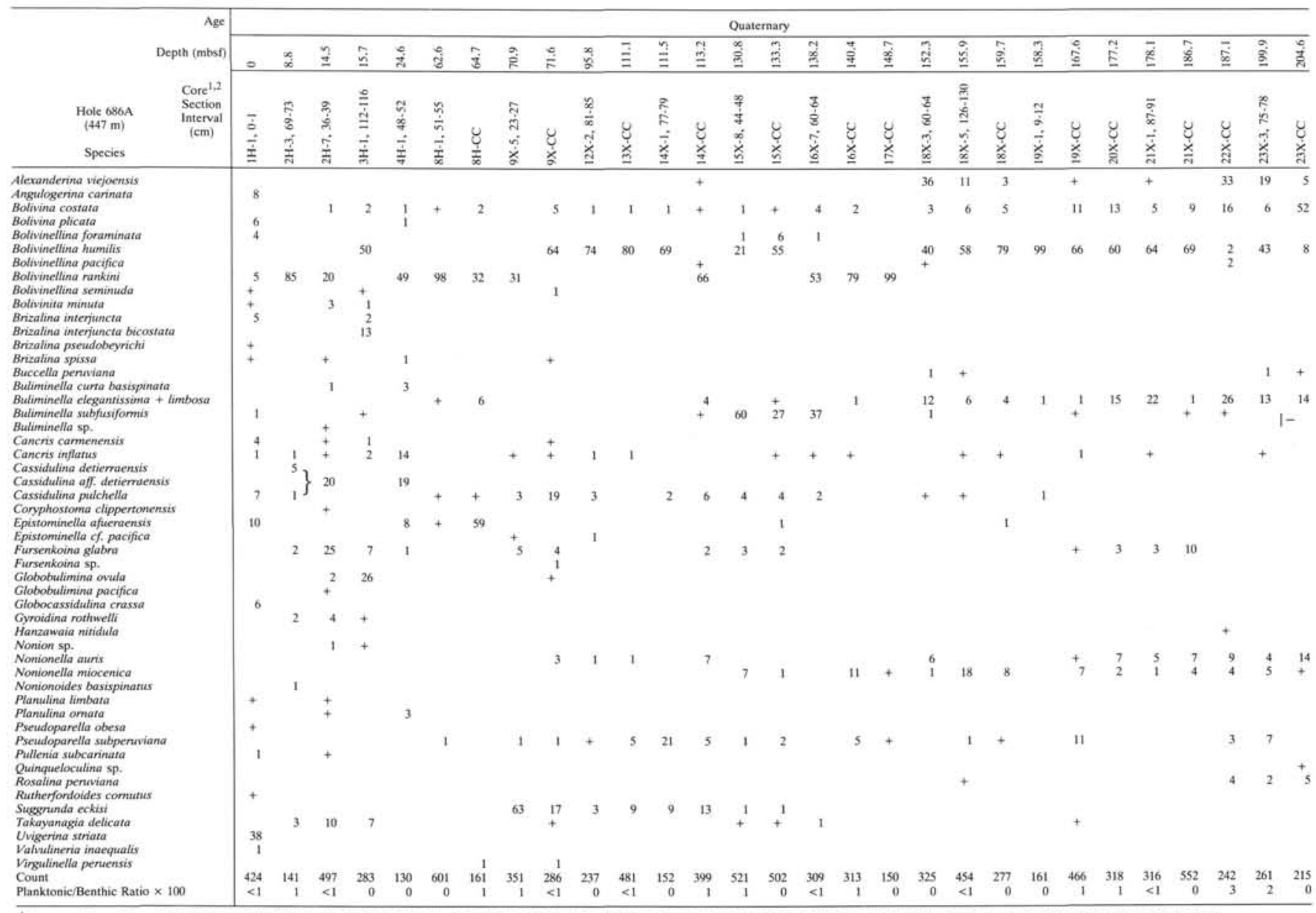

Barren of foraminifers: $1 \mathrm{H}-3,64-68 ; 1 \mathrm{H}-\mathrm{CC} ; 3 \mathrm{H}-\mathrm{CC} ; 4 \mathrm{H}-\mathrm{CC} ; 5 \mathrm{H}-2,136-140 ; 5 \mathrm{H}-3,69-73 ; 5 \mathrm{H}-\mathrm{CC} ; 6 \mathrm{H}-3,76-80 ; 6 \mathrm{H}-\mathrm{CC} ; 7 \mathrm{H}-2,38-42 ; 7 \mathrm{H}-\mathrm{CC} ; 10 \mathrm{X}-3,102-106 ; 10 \mathrm{X}-\mathrm{CC} ; 11 \mathrm{X}-1,62-66 ; 11 \mathrm{X}-\mathrm{CC} ; 17 \mathrm{X}-3,73-77 ; 20 \mathrm{X}-3,74-78$.
Counts less than 100; $2 \mathrm{H} \cdot \mathrm{CC} ; 19 \mathrm{X}-6,59-63$.

contains an assemblage indicative of upper bathyal, lowoxygen conditions. The upper $25 \mathrm{~m}$ of the section was deposited in the lower part of the upper bathyal under current-dominated conditions, with signature species Angulogerina carinata, Uvigerina striata, Bolivina interjuncta, and Cassidulina detierraensis.

Fluctuations in sea level are registered in the early part of the stratigraphic section, but are not detectable in the later assemblages from the upper bathyal because no change in biotopes was involved. Subsidence of Site 686 from $100 \mathrm{~m}$ or less to its present depth of $447 \mathrm{~m}$ apparently occurred gradually, during the Quaternary.

\section{LOWER-SLOPE SITES}

Percentage frequencies of species occurring at the three deep sites and estimates of species abundance at the fourth deep site (Tables 7 through 10) reveal temporal assemblage changes that also reflect sediment redeposition and subsidence of the outer continental margin. The sites of the $9^{\circ} \mathrm{S}$ transect are discussed first, followed by the sites of the $10^{\circ} \mathrm{S}$ transect.

\section{Holes 683A and 683B (3072 $\mathrm{m}$, offshore Trujillo)}

This lower-slope site lay in upper bathyal depths during the middle Eocene. The assemblages are characterized by various bolivinids, buliminids, and buliminellids, along with traces of some species having deeper water affinities, such as Asterigerina crassaformis and Nuttallides truempyi. Well-represented species include Bolivina maculata, Bolivinellina basisenta, Bulimina chirana, Buliminella peruviana, Buliminellita mirifica, Globocassidulina globosa, and Stichocassidulina thalmanni.

Following an unconformity, middle Miocene deposits contain lower bathyal assemblages, indicating subsidence of about $1500 \mathrm{~m}$ in $26 \mathrm{~m} . \mathrm{y}$., or about $60 \mathrm{~m} / \mathrm{m} . \mathrm{y}$. Species identifying these lower bathyal deposits include Cibicidoides trinitatensis, Hansenisca zealandica, Melonis pompilioides, and Planulina renzi, among others.

These middle Miocene lower bathyal assemblages are separated by a barren interval from a section containing a middle bathyal assemblage with Bolivina alazanensis, Uvigerina gallowayi, $U$. mantaensis, and $U$. rustica. Associated high numbers of the Bolivina vaughani $\mathrm{Gr}$. might have been transported from the shelf. Data from planktonic microfossils (Schrader, Martini, this volume) indicate that this middle Miocene section represents a slump deposit that contains blocks of intact sediment.

Lower bathyal sedimentation continued in the late Pliocene and Quaternary, with an assemblage in which Uvigerina senticosa is prominent. Up to $85 \%$ Bolivina costata and some other shelf and upper-slope species indicate high amounts of 


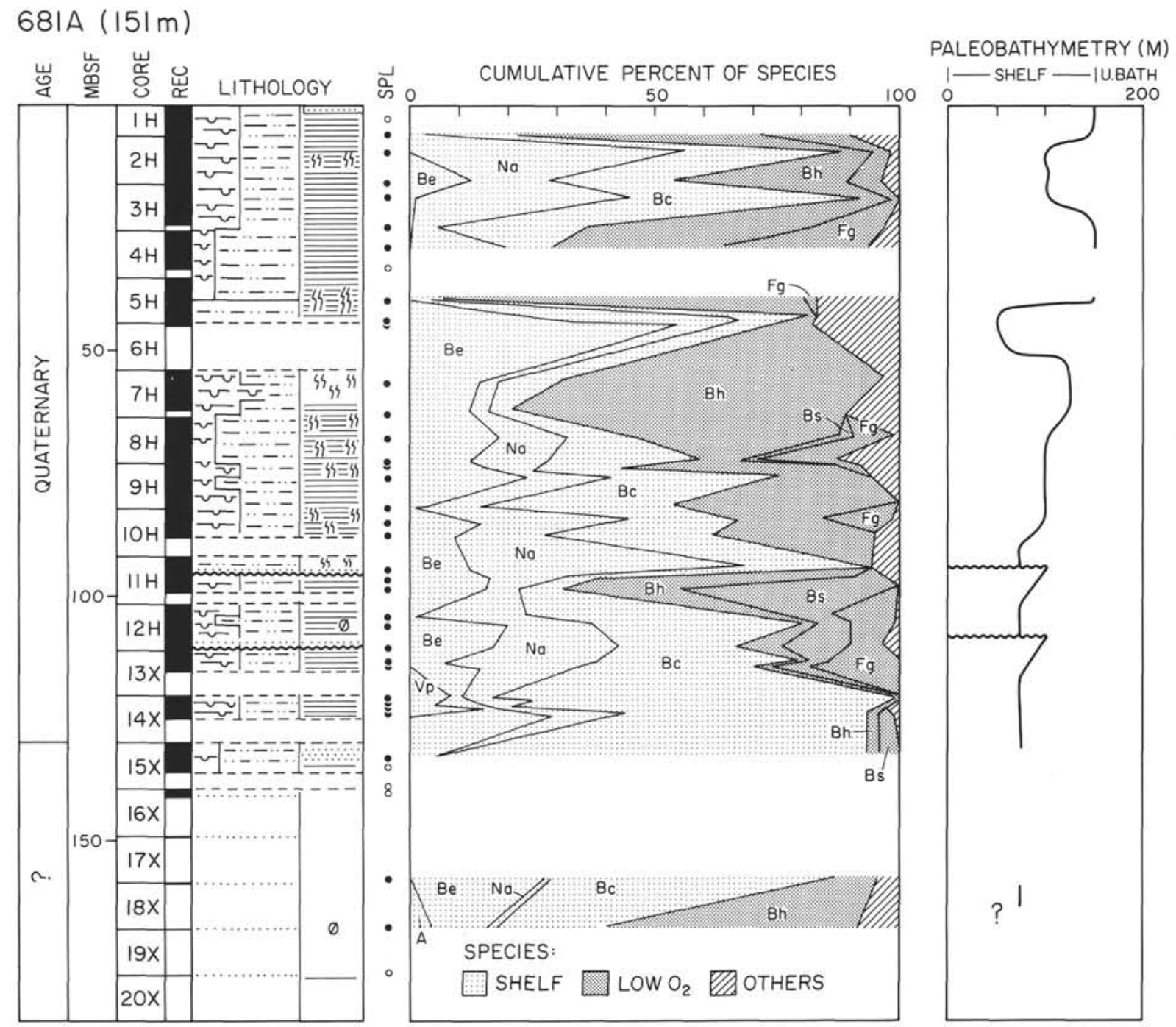

Figure 7. Lithofacies, biofacies, and paleobathymetry at Hole 681A. Shelf species: $\mathrm{A}=$ Ammobaculites $\mathrm{sp} ., \mathrm{Bc}=$ Bolivina costata, $\mathrm{Be}=$ Buliminella elegantissima, $\mathrm{Na}=$ Nonionella auris, $\mathrm{Vp}=$ Virgulinella peruensis. Low-oxygen species: $\mathrm{Bh}=$ Bolivinellina humilis, $\mathrm{Bs}=$ Buliminella subfusiformis, $\mathrm{Fg}=$ Fursenkoina glabra .

downslope sediment transport, particularly in the middle to late Quaternary.

\section{Hole 685A (5071 m, offshore Trujillo)}

The Quaternary and upper Miocene section recovered at this site, which is located below the present CCD, is mostly barren of benthic foraminifers or these are rare. Horizons containing common foraminifers consist of species transported from various shelf to lower bathyal biotopes, mostly the shelf species Bolivina costata (to $95 \%$ ) in the Quaternary and Bolivina vaughani (to $50 \%$ ) in the late Miocene. Data from planktonic microfossils (Schrader, this volume) indicate that the lower upper Miocene deposits represented here are part of the slump that affected the Site 683 section.

\section{Hole 682A (3789 m, offshore Lima)}

Middle Eocene deposits at the base of the cored section contain an outermost shelf-upper bathyal assemblage similar to that recovered at Site 683 , with Bolivinellina $b a$ sisenta, Bulimina chirana, Cyclammina simiensis, Globocassidulina globosa, and Stichocassidulina thalmanni as principal components, and other species described from formations exposed in northern Peru. Sample 112-682-44XCC, above a late Eocene hiatus, contains reworked, silicified Eocene foraminifers as well as reworked nannofossils, including Late Cretaceous, nearshore, and shallow-water species (Martini, this volume). Following the hiatus and subsidence, the Oligocene and lower Miocene sections were deposited at middle bathyal depths. The Oligocene assemblage resembles that of the Goajira Peninsula, Columbia (Becker and Dusenbury, 1958) and the early Miocene assemblage that of the Agua Salada Formation (Renz, 1948). Uvigerina gallowayi, U. mantaensis, and $U$. rustica occur in the early Miocene section, rather than in the middle Miocene, as at Site 683.

A late Miocene slump is indicated by diatoms and nannofossil data similar to that reported for the other sites. Discrete benthic foraminiferal assemblages are found throughout this interval, suggesting material transported from outer-shelf as well as upslope bathyal sources. The presence of high percentages of Buliminella elegantissima limbosa throughout the late and middle Miocene section indicates persistent transport from a shallow source. Middle bathyal indicator species include Ambitropus thalmanni, 


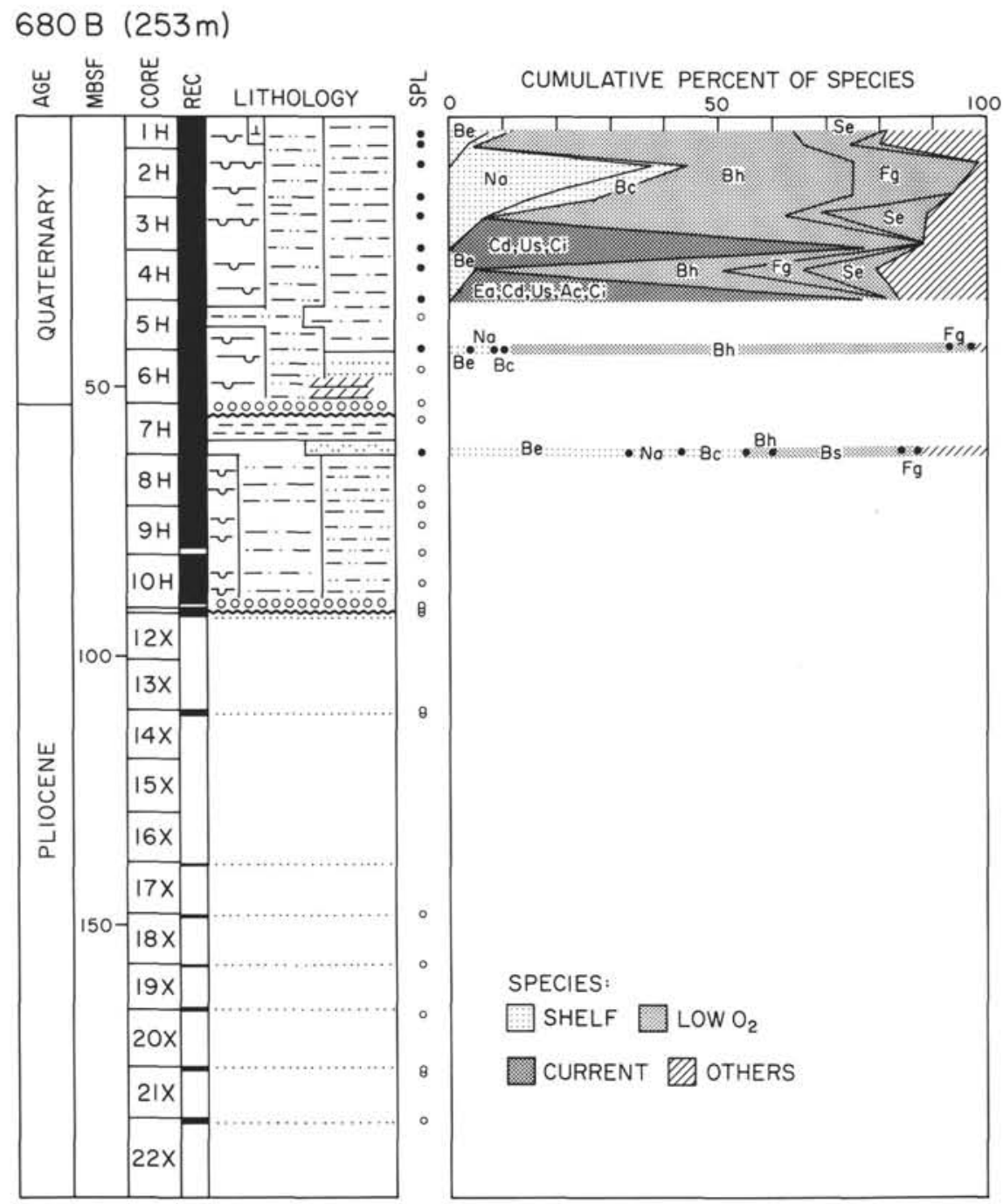

PALEOBATHYMETRY (M)

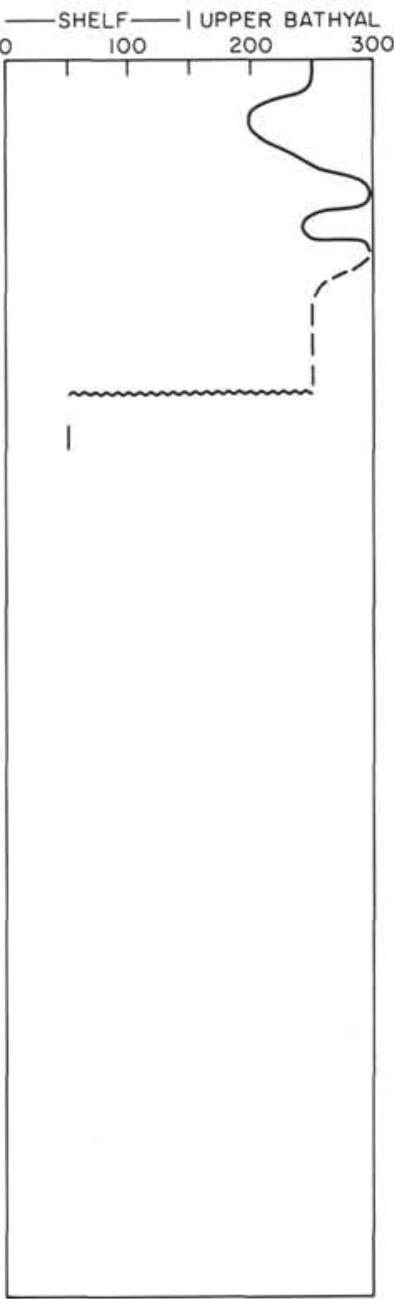

Figure 8. Lithofacies, biofacies, and paleobathymetry at Hole $680 \mathrm{~B}$. Shelf species: $\mathrm{Bc}=$ Bolivina costata, Be $=$ Buliminella elegantissima, $\mathrm{Na}=$ Nonionella auris. Low-oxygen species: $\mathrm{Bh}=$ Bolivinellina humilis, $\mathrm{Bs}=$ Buliminella subfusiformis, $\mathrm{Fg}=$ Fursenkoina glabra, $\mathrm{Se}=$ Suggrunda eckisi. Current species: $\mathrm{Ac}=$ Angulogerina carinata, $\mathrm{Ci}=$ Cancris inflatus, $\mathrm{Cd}=$ Cassidulina detierraensis, $\mathrm{Ea}=$ Epistominella afueraensis, $\mathrm{Us}=$ Uvigerina striata.

Epistominella smithi, Hansenisca multilocula, and Uvigerina peregrina dirupta. Sample 112-682A-15X-CC is dominated by Bolivina granti. Sample 112-682A-8X-CC, a discordant early Pliocene sample with high percentages of Bolivinellina girardensis and $B$. goudkoffi, also was displaced.

The late Pliocene and Quaternary sections contain Uvigerina senticosa-bearing lower bathyal assemblages. Up to $27 \%$ transported Bolivina costata and several slope species are mixed with the in-situ assemblage.

\section{Holes 688A and 688E (3819 m, offshore Lima)}

The Eocene section penetrated at the base of this lower bathyal site contains a history of shallow-water deposition in shelf and upper bathyal environments. The shallowest biofacies, containing rare specimens of Spiroplectammina gryzbowski, Cyclammina sp., and Virgulinella sp., occurs in Sample 112-688E-45R-CC. Plant debris was also noted in this sample. Subsequent early Eocene deposits indicate deepening to upper bathyal conditions in Sample 112-688E-43R-CC, where deep-sea species, such as Cibicidoides grimsdalei and Oridorsalis umbonatus, are coincident with shelf-dwelling
Globocassidulina globosa, and then a shallowing again to shelf conditions in Core 112-688E-36R, where a buliminid assemblage predominates. Following a hiatus, middle Eocene deposition is characterized by sparse faunas in sandy matrix that may be reworked under shallow shelf conditions and/or represent downhole contamination. Bathysiphon eocenica, Nodosaria lonqiscata, Oridorsalis umbonatus, and Stilostomella spp. are represented (by single specimens), as well as some Eocene indexes, such as Bulimina chirana.

After a hiatus, early Miocene assemblages in which Uvigerina gallowayi and Uvigerina mantaensis occur with Bulimina alazanensis, Hansenisca altiformis, and Oridorsalis umbonatus suggest upper middle bathyal conditions and subsidence of 400 to $1400 \mathrm{~m}$, following Eocene deposition. Late Miocene samples are barren of benthic foraminifers at this site.

In the Quaternary, lower bathyal assemblages with common to abundant Uvigerina senticosa, Melonis affinis, Melonis pompilioides, and Pullenia bulloides prevailed. Transported species, particularly Bolivina costata, compose up to $50 \%$ of some of the layers sampled; however, other samples contain only $5 \%(112-688 \mathrm{~A}-4 \mathrm{H}-\mathrm{CC})$ to $10 \%(112-688 \mathrm{~A}-7 \mathrm{H}-$ 


\section{J. M. RESIG}

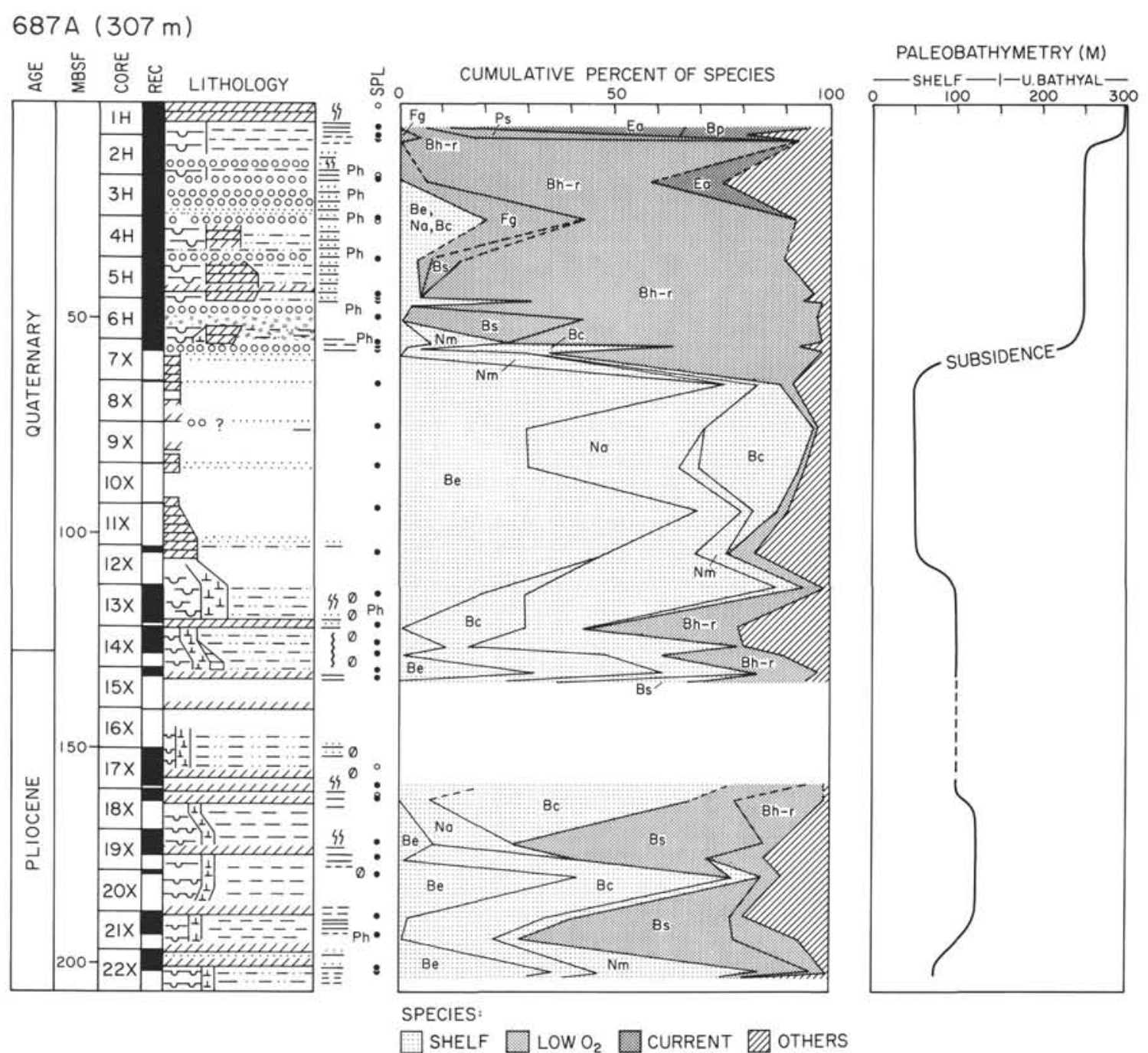

Figure 9. Lithofacies, biofacies, and paleobathymetry at Hole 687A. Shelf species: $\mathrm{Bc}=$ Bolivina costata, Be $=$ Buliminella elegantissima, $\mathrm{Na}=$ Nonionella auris, $\mathrm{Nm}=$ Nonionella miocenica. . Low-oxygen species: $\mathrm{Bh}-\mathrm{r}=$ Bolivinellina humilis-rankini, $\mathrm{Bs}=$ Buliminella subfusiformis, $\mathrm{Fg}=$ Fursenkoina glabra, $\mathrm{Ps}=$ Pseudoparrella subperuviana. Current species: $\mathrm{Bp}=$ Bolivina plicata, $\mathrm{Ea}=$ Epistominella afueraensis.

CC) transported tests. In Sample 112-688A-4H-CC, specimens of the Angulogerina carinata-Cancris inflatus biofacies prevail among the $50 \%$ transported tests, which is unusual because small, rather than large, tests are generally transported as far as the lower slope.

\section{PERU MARGIN ASSEMBLAGES}

A number of benthic foraminiferal biofacies, characterized by one or more dominant species with distinctive associated species, were sampled, sometimes repeatedly, in the Peru margin boreholes. Some key species, grouped according to age and paleobathymetry, are illustrated in Plates 1 through 5. These biofacies, with their dominant species shown by asterisk, are given below:

Quaternary and Late Tertiary Shelf Biofacies (PI. 1)

Alexanderina viejoensis

* Bolivina costata

Buccella peruviana

* Buliminella elegantissima

*Buliminella elegantissima limbosa

Hanzawaia nitidula

\section{*Nonionella auris \\ * Nonionella miocenica \\ Nonionoides basispinatus \\ Rosalina peruviana \\ Virgulinella peruensis}

This assemblage occurs in all of the shallow sites. Large-size Bolivinellina humilis are concurrent with these species up to about mid-shelf paleodepths, which may have represented the shoreward extent of low-oxygen conditions. Bolivina costata, a small, lightweight, yet structurally sound species because of its longitudinal costae, tends to be winnowed from the shelf and redeposited offshore, perhaps from suspension. This species is the dominant transported species reaching the lower slope, where it composes up to $94 \%$ of the total benthic foraminifers in some horizons of Site 685 and up to $85 \%$ at Site 683 , both in the $9^{\circ} \mathrm{S}$ transect; transported $B$. costata makes up to $27 \%$ of the benthic foraminifers at Site 682 and an estimated $50 \%$ at Site 688 , in the lower slopes of the $11^{\circ} \mathrm{S}$ transect. Bolivina costata did not occur stratigraphically below the Pliocene; however, Miocene assemblages show downslope displacement of members of the morphologically $\operatorname{similar} B$. vaughani group. 

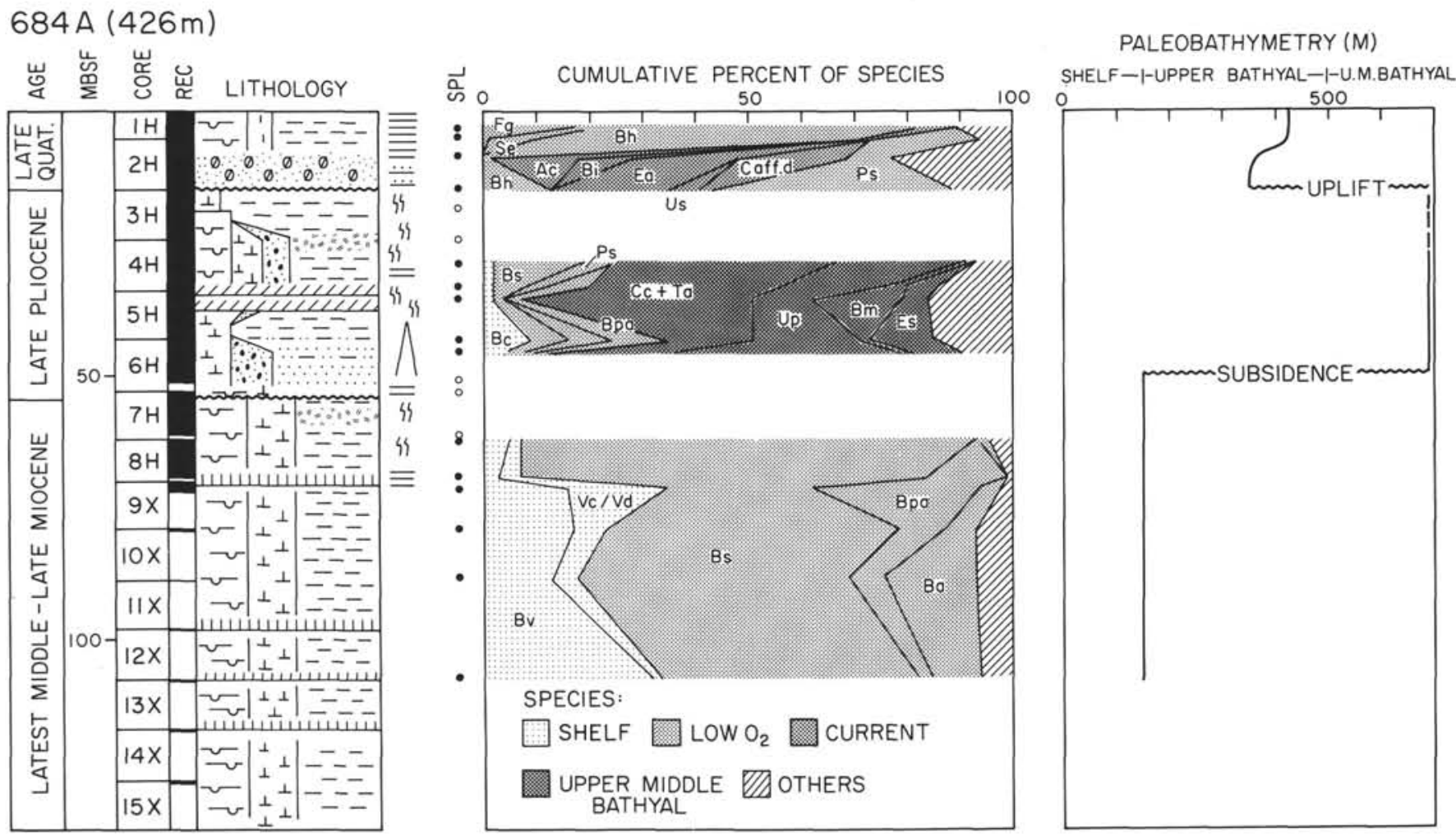

Figure 10. Lithofacies, biofacies, and paleobathymetry at Hole $684 \mathrm{~A}$. Shelf species: $\mathrm{Bc}=$ Bolivina costata, $\mathrm{Bv}=$ Bolivina vaughani, Vc $=$ Valvulineria cf. compressa, $\mathrm{Vd}=$ Valvulineria $\mathrm{cf}$. depressa. Low-oxygen species: $\mathrm{Ba}=$ Bolivina $\mathrm{cf}$. advena, $\mathrm{Bh}=$ Bolivinellina humilis, $\mathrm{Bp}=$ Bolivinellina pacifica, $\mathrm{Bs}=$ Buliminella subfusiformis, $\mathrm{Fg}=$ Fursenkoina glabra, $\mathrm{Ps}=$ Pseudoparrella subperuviana, $\mathrm{Se}=$ Suggrunda eckisi . Current species: $\mathrm{Ac}=$ Angulogerina carinata, $\mathrm{Bi}=$ Brizalina interjuncta, $\mathrm{Cd}=$ Cassidulina aff. detierraensis, Ea $=$ Epistominella afueraensis, $\mathrm{Us}=$ Uvigerina striata . Upper-Middle Bathyal species: $\mathrm{Bm}=$ Bolivinita minuta, $\mathrm{Cc}=$ Cassidulina cushmani, Es $=$ Epistominella smithi, $\mathrm{Ta}=$ Takayanagia asanoi, $\mathrm{Up}=$ Uvigerina peregrina and $U$. dirupta.

\section{Quaternary Outer-Shelf-Upper Bathyal,} Oxygen-Minimum Biofacies (PI. 2, Figs. 1-8)

*Bolivinellina humilis

Buliminella subfusiformis

"Ellipsoglandulina" fragilis

Fursenkoina glabra

Parabolivina peruensis

Suggrunda eckisi

"Ellipsoglandulina" fragilis and Parabolivina peruensis occur predominantly in the Quaternary section of Site 679 and may favor a particular level of the gradient in low-oxygen conditions. Suggrunda eckisi does not occur at Site 681 , the shallowest site. Otherwise, this assemblage occurs in all of the shallow sites; some of its members extend back to late Miocene time.

\section{Quaternary Lower-Upper Bathyal Current Biofacies}

$$
\text { (PI. 2, Figs. 9-17) }
$$

*Angulogerina carinata

Bolivina plicata

Brizalina interjuncta

Cancris carmenensis

Cancris inflatus

Cassidulina detierraensis

Epistominella afueraensis

Gyroidina rothwelli

Uvigerina semitrigona

Uvigerina striata
This assemblage represents a collection of robust species concentrated in foraminiferal sands through current action during the Quaternary in certain horizons of shallow sites in all three traverses. Comparable assemblages occur in the Pliocene Charco Azul Formation of Panama (Coryell and Mossman, 1942) and in upper Pliocene exposures in the Gulf of California (Natland, 1950).

\section{Quaternary Lower Bathyal Biofacies} (Pl. 3, Figs. 1-6)

\section{Globocassidulina depressa \\ Melonis pompilioides \\ Oridorsalis umbonatus \\ Pseudoparrella exigua \\ Pullenia bulloides \\ Uvigerina senticosa}

This species association occurs in the Quaternary and Pliocene sections of all of the deep sites. The in-situ lower bathyal assemblage is mostly outnumbered by Bolivina costata that has been transported from the shelf biofacies, as mentioned previously.

\section{Pliocene Upper-Middle Bathyal Biofacies (Pl. 3, Figs. 7-10)}

Bolivinita minuta

Cassidulina cushmani

Epistominella smithi

Plectofrondicularia californica 
$679 D / E(440 m)$
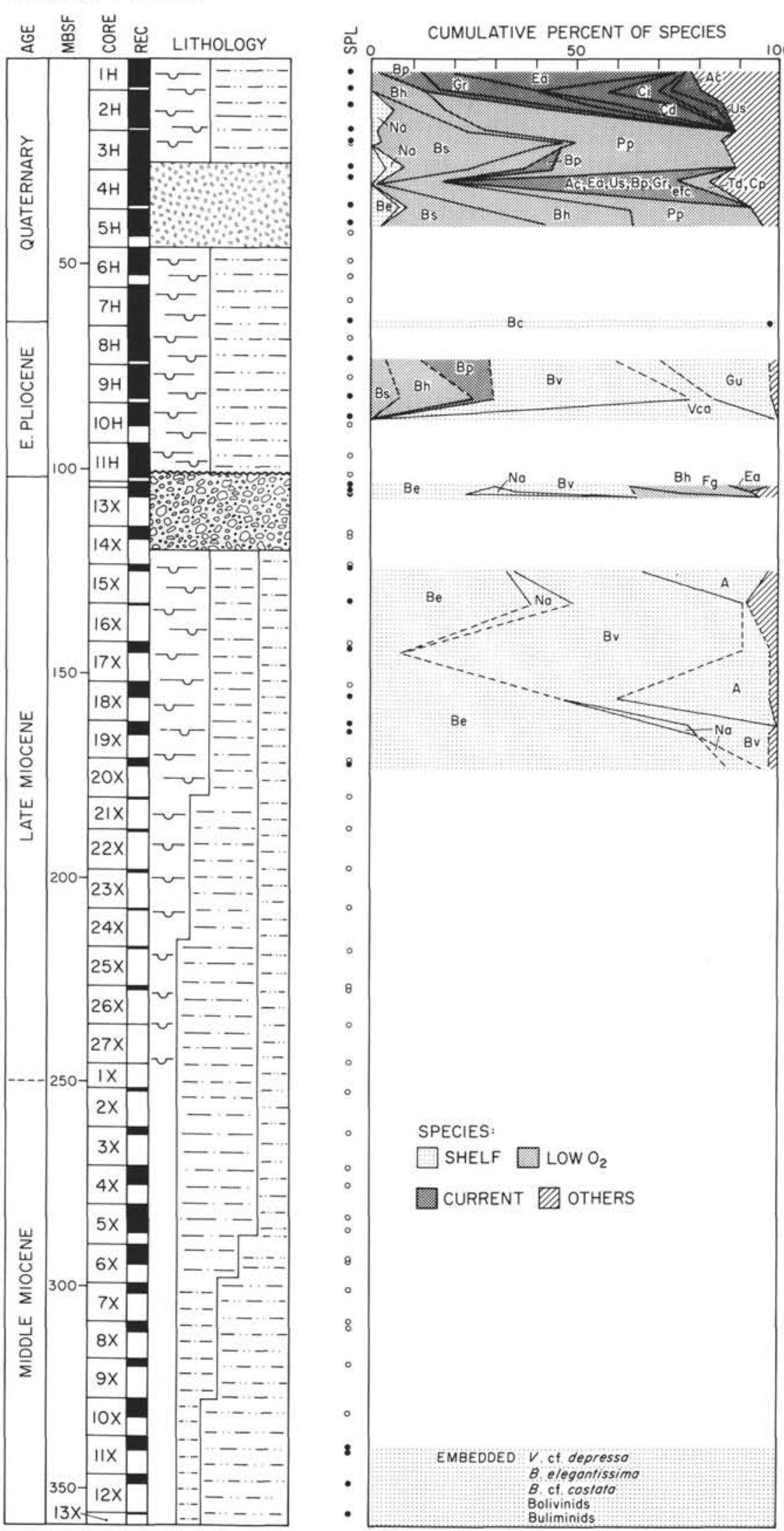

PALEOBATHYMETRY (M)

SHELF-I-UPPER BATHYAL

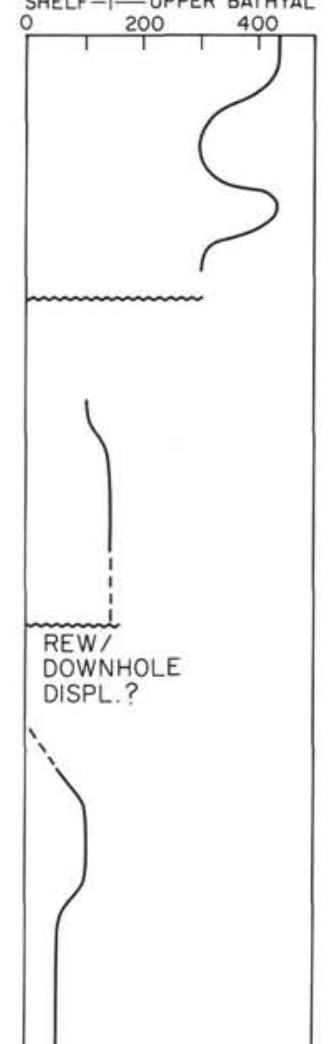

Figure 11. Lithofacies, biofacies, and paleobathymetry at Holes 679D and 679E. Shelf species: A = Ammobaculites sp., $\mathrm{Bv}=$ Bolivina vaughani, $\mathrm{Be}=$ Buliminella elegantissima, $\mathrm{Gu}=$ Galliherina uvigerinaformis (shelf edge), $\mathrm{Na}=$ Nonionella auris, $\mathrm{Vca}=$ Valvulineria californica (shelf edge). Low-oxygen species: $\mathrm{Bh}=$ Bolivinellina humilis, $\mathrm{Bs}=$ Buliminella subfusiformis, $\mathrm{Pp}=$ Parabolivina peruensis. 
686 A $(447 m)$

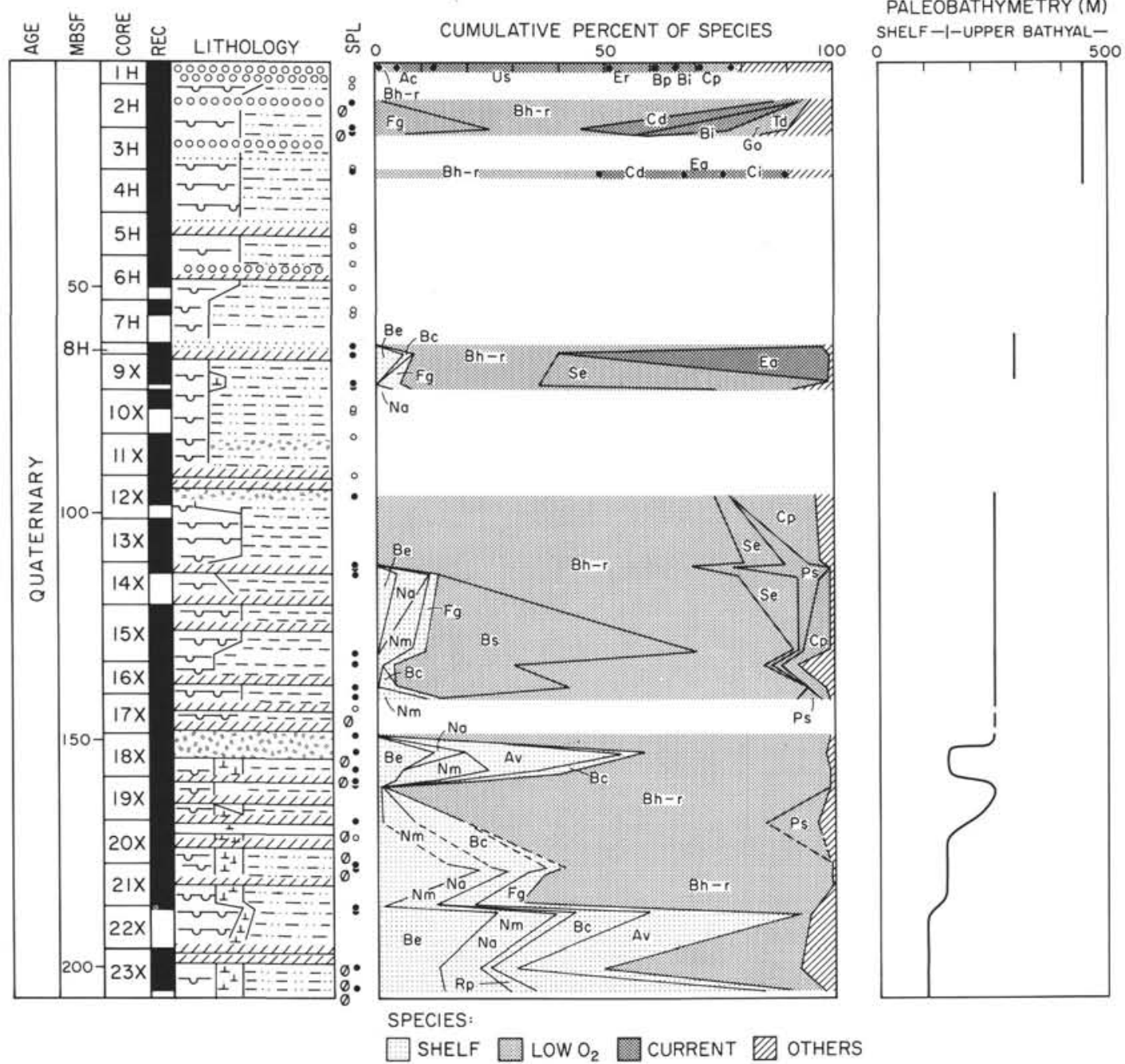

Figure 12. Lithofacies, biofacies, and paleobathymetry at Hole 686A. Shelf species: $\mathrm{Av}=$ Alexanderina viejoensis, $\mathrm{Bc}=$ Bolivina costata, $\mathrm{Be}=$ Buliminella elegantissima, $\mathrm{Na}=$ Nonionella auris, $\mathrm{Nm}=$ Nonionella miocenica, $\mathrm{Rp}$ $=$ Rosalina peruviana . Low-oxygen species: $\mathrm{Bh}-\mathrm{r}=$ Bolivinellina humilis-rankini, $\mathrm{Bs}=$ Buliminella subfusiformis, $\mathrm{Cp}=$ Cassidulina pulchella, $\mathrm{Fg}=$ Fursenkoina glabra, $\mathrm{Go}=$ Globobulimina ovula, $\mathrm{Ps}=$ Pseudoparrella subperuviana, $\mathrm{Se}=$ Suggrunda eckisi, $\mathrm{Td}=$ Takayanagia delicata . Current species: $\mathrm{Ac}=$ Angulogerina carinata, $\mathrm{Bp}=$ Bolivina plicata, $\mathrm{Bi}=$ Brizalina interjuncta, $\mathrm{Ci}=$ Cancris inflatus, $\mathrm{Cd}=$ Cassidulina detierraensis, Ea $=$ Epistominella afueraensis.

\section{Takayanagia delicata}

This assemblage, which consists of long-ranging species, was recovered intact only at Site 684 in the $9^{\circ} \mathrm{S}$ transect, but its individual components occur frequently in deposits of the deep sites, where they accumulated as a result of downslope transport. Plectrofrondicularia californica was assigned to the lower bathyal biofacies by Ingle (1980), but its association in the Pliocene deposits off Peru indicates a shallower habitat there.

\section{Late Miocene-Early Pliocene Outermost Shelf Biofacies} (Pl. 3, Figs. 11-19)

*Galliherina uvigerinaformis

Valvulineria californica

Valvulineria cf. compressa

Valvulineria cf. depressa
This assemblage was sampled at Hole $684 \mathrm{~A}$ in the $9^{\circ} \mathrm{S}$ transect and at Hole 679D in the $11^{\circ} \mathrm{S}$ transect.

\section{Late Miocene Middle Bathyal Biofacies (PI. 4, Figs. 11-12)}

Ambitropus thalmanni

Bolivina granti

Brizalina girardensis

Hansenisca multilocula

Rotorbinella garveyensis

Uvigerina mantaensis

Uvigerina marksi

Uvigerina peregrina dirupta

These species were sampled at Site 682 . Bolivina vaughani $\mathrm{Gr}$., interpreted as being transported from the shelf, is commonly associated with these species. A similar assemblage 
Table 6. Percentage of species representation, Hole 687A (307 m).

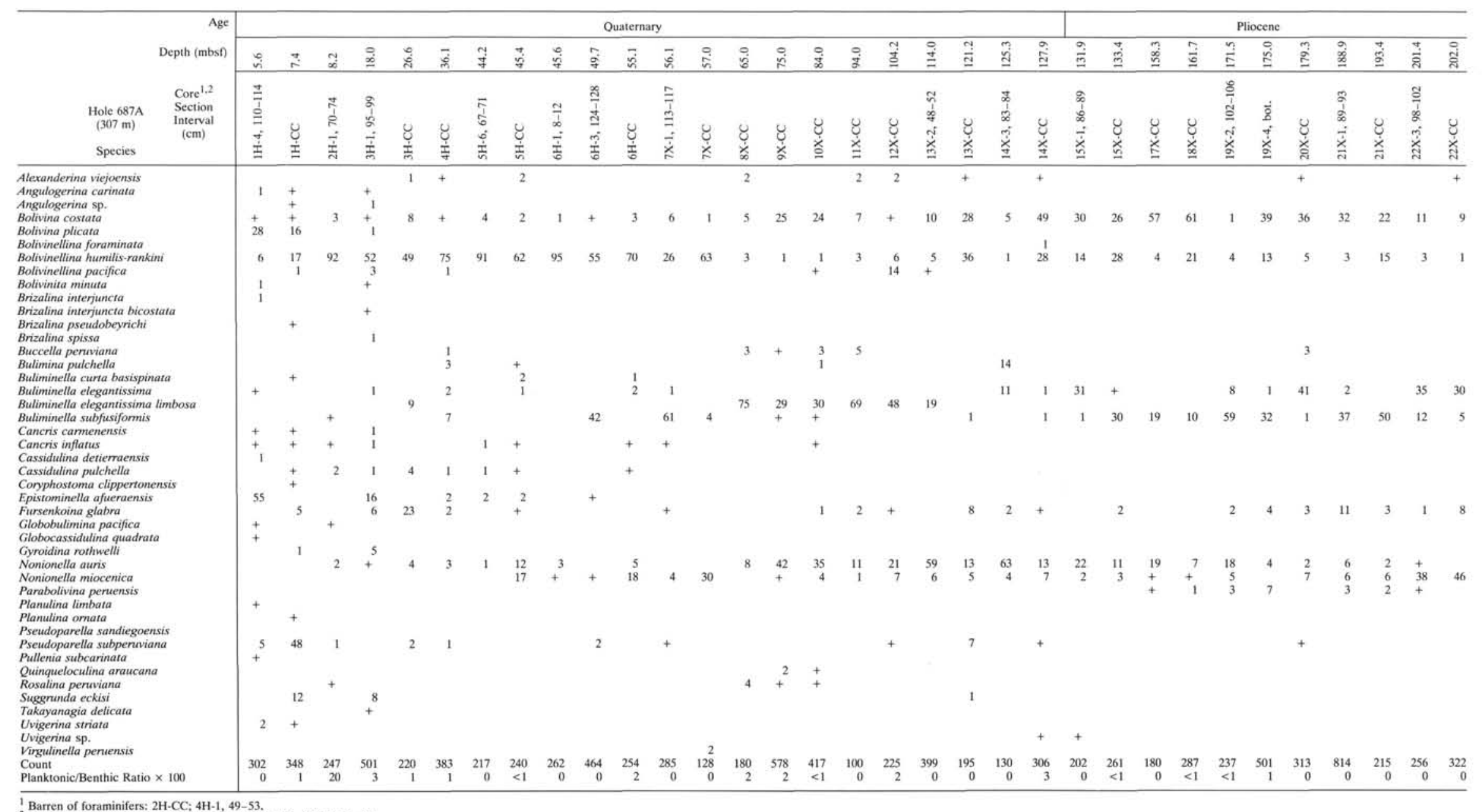

1 Barren of foraminifers: $2 \mathrm{H}-\mathrm{CC} ; 4 \mathrm{H}-1,49-53$.
2 Counts less than 100: $1 \mathrm{H}-1,13-17$; 17X-3, 130-134; 18X-2, 56-60. 
occurs in the Miocene Charapoto Formation of Ecuador (Cushman and Stevenson, 1948).

\author{
Middle Miocene Middle Bathyal Biofacies \\ (PI. 4, Figs. 13-16) \\ Brizalina pisciformis \\ Siphonodosaria paucistriata \\ ${ }^{*}$ Uvigerina gallowayi \\ Uvigerina mantaensis \\ *Uvigerina rustica
}

These species occur in the three sites that were drilled deep enough to tap middle Miocene strata. A similar assemblage occurs in the Manta Shale of Ecuador and in Venezuelan material (Cushman, 1929), as well as in the Venezuelan Agua Salada Group (Renz, 1948).

\section{Middle Miocene Lower Bathyal Biofacies}

(Pl. 4, Figs. 17-20)

Cibicidoides kullenbergi

* Cibicidoides trinitatensis

Hansenisca zealandica

*Planulina renzi

This species association occurs at Site 683 and is considered to be the deepest facies sampled, with many of the associated species occurring in the deep sea (Parker, 1964; Douglas, 1973).

\section{Middle Eocene Shelf and Upper Bathyal Biofacies (Pl. 5, Figs. 1-5) \\ Asterigerina crassaformis \\ Bolivinellina basisenta \\ Bulimina chirana \\ Buliminella peruviana \\ Cyclammina simiensis \\ Globocassidulina globosa \\ Stichocassidulina thalmanni}

Various combinations of species, described from the Eocene formations of northern Peru (Cushman and Stone, 1947, Chira Shale; Cushman and Stone, 1949b, Verdun Formation), coastal Ecuador (Cushman and Stainforth, 1947), and Chile (Todd and Kniker, 1952), occur in the basal rocks drilled at Sites 682, 683, and 688. These assemblages are variously considered shelf or upper bathyal deposits because of the preponderance of buliminids and bolivinids. The interpreted shallowest shelf biofacies contains the agglutinates Cyclammina simiensis and Bathysiphon eocenica, in contrast to the modern deep-water habitats of these genera.

\section{SUMMARY AND CONCLUSIONS}

Benthic foraminiferal biofacies in the $9^{\circ} \mathrm{S}$ transect off Trujillo indicate an upper bathyal environment at lower slope Site 683 during middle Eocene time that is characterized by species reported in northern Peru formations. During the succeeding $26 \mathrm{~m} . \mathrm{y}$., for which no sedimentary record was preserved, this part of the margin subsided about $1500 \mathrm{~m}$ to lower bathyal depths. Evidence from diatoms and nannofossils suggests that middle Miocene, middle bathyal assemblages of benthic foraminifers were emplaced at Site 683 as part of a slump. Late Miocene deposits of Site 684 contain outer-shelf to upper-slope benthic foraminifers, a somewhat shallower biofacies than that now present, indicative of a low stand of sea level during the late Miocene. No deposits of late Miocene age occur at Site 683, and deposits of this age are partly missing at Site 685 , which has been situated below the $\mathrm{CCD}$ from late Miocene to the present time. Intervals barren of benthic foraminifers characterize the Pliocene sections at the three sites. However, at Site 684 , a well-preserved late Pliocene upper-middle bathyal biofacies indicates subsidence of about $400 \mathrm{~m}$ from the late Miocene outer-shelf to upper bathyal biofacies. An oxygen-minimum environment, indicated by Bolivinellina humilis, occurs in the late Quaternary section of Site 684 .

The small shelf species, Bolivina costata, is preferentially transported downslope and is a substantial contributor to Pliocene and Quaternary assemblages of the deep sites, where turbidite sedimentation is prevalent.

Benthic foraminiferal biofacies of the $11^{\circ} \mathrm{S}$ transect also record shelf or upper bathyal biotopes at lower-slope Sites 688 and 682 during the Eocene and subsequent subsidence of this margin to lower bathyal depths in late Oligocene to early Miocene time. Middle Miocene middle bathyal biofacies occur sporadically at these deep sites and may have been emplaced through slumping, as in the northern transect. Early Pliocene sedimentation also may have been affected by the slumping, as indicated by the middle bathyal assemblages at deep Site 682. Middle and late Miocene deposits at Site 679 reflect deposition on the outer shelf, with subsequent deposits indicating subsidence to the present upper bathyal oxygen-minimum environment. The shallow sites of this traverse reflect changes in sea level as shifts between shelf biofacies, with abundant Nonionella, and oxygen-minimum biofacies, with abundant Bolivinellina humilis.

The $13^{\circ} \mathrm{S}$ Pisco Basin Sites 686 and 687 reveal general subsidence of late Pliocene and Quaternary sections of shifting shelf and upper bathyal environments, related to changes in sea level.

These paleobathymetric analyses of benthic foraminifers thus provide evidence of the seaward extent of continental margin deposits off Peru and of their subsidence. Environmental, evolutionary, and biogeographic implications of the assemblages must be evaluated further.

\section{ACKNOWLEDGMENTS}

The shipboard scientific party and crew of the Joides Resolution provided the inspiration and material for this research, which was supported by the Ocean Drilling Program in a post-cruise grant. Don Sims photographed the foraminifers on the shipboard ISI-SX-25 scanning electron microscope. Scot Izuka and Bryant Waters prepared samples in the shore laboratory. The in-house reviews by my colleague, William Coulbourn and by Hawaii Institute of Geophysics Editor Diane Henderson as well as external reviews by James Ingle and Kristin McDougall improved the manuscript. I gratefully acknowledge the help of these supporters and of Roland von Huene, whose prodding brought this report to completion. This is Hawaii Institute of Geophysics Contribution 2229.

\section{REFERENCES}

Bandy, O. L., 1961. Distribution of foraminifera, radiolaria and diatoms in sediments of the Gulf of California. Micropaleontology, 7:1-26.

Bandy O. L., and Rodolfo, K., 1964. Distribution of foraminifera and sediments, Peru-Chile Trench area. Deep-Sea Res., 11:817-837.

Becker, L., and Dusenbury, A. N., Jr., 1958. Mio-Oligocene (Aquitanian) foraminifera from the Goajira Peninsula, Colombia. Cushman Found. Foram. Res. Spec. Publ., 4:1-48.

Berger, W., 1970. Planktonic foraminifera: selective solution and the lysocline. Mar. Geol., 8:111-138.

Boltovskoy, E., 1976. Distribution of foraminifera of the South American region. In Hedley, R. H., and Adams, C. G. (Eds.), Foraminifera, Vol. 2: New York (Academic Press), 171-236. 
Boltovskoy, E., and Theyer, F., 1970. Foraminiferos Recientes de Chile Central. Revista del Museo Argentino de Ciencias Naturales, Hidrobiologia, 2:279-378.

Boltovskoy, E., and Wright, R., 1976. Recent Foraminifera: The Hague (W. Junk).

Brooks, R., Presley, B., and Kaplan, I., 1968. Trace elements in the interstitial waters of marine sediments. Geochim. Cosmochim. Acta, 32:397-414.

Burnett, W., 1977. Geochemistry and origin of phosphate deposits off Peru and Chile. Geol. Soc. Am. Bull., 88:813-823.

Burnett, W., Veeh, H., and Soutar, A., 1980. U-series oceanographic and sedimentary evidence in support of Recent formation of phosphate nodules off Peru. Soc. Econ. Paleontol. Mineral. Spec. Publ., 29:61-71.

CLIMAP, 1976. The surface of the Ice-Age Earth. Science, 191:11311137.

Coryell, H., and Mossman, R., 1942. Foraminifera from the Charco Azul Formation, Pliocene of Panama. J. Paleontol., 16:233-246.

Coulbourn, W., and Moberly, R., 1988. Deposition and erosion in a submarine canyon system, Arequipa fore-arc basin, off southern Peru. Geol. Soc. Am. Abstr. Programs, 20:A197. (Abstract).

Cushman, J. A., 1929. A later Tertiary fauna of Venezuela and other related regions. Contr. Cushman Lab. Foram. Res., 5:77-105.

Cushman, J. A., and Gray, H., 1946. A foraminiferal fauna from the Pliocene of Timms Point, California. Cushman Lab. Foram. Res. Spec. Publ., 19:1-46.

Cushman, J. A., and McCulloch, I., 1940. Some Nonionidae in the collections of the Allan Hancock Foundation. Allan Hancock Pacific Exped., 6:145-178.

1942. Some Virgulininae in the collections of the Allan Hancock Foundation. Allan Hancock Pacific Exped., 6:179-230. 1948. The species of Bulimina and related genera in the collections of the Allan Hancock Foundation. Allan Hancock Pacific Exped., 6:231-294.

Cushman, J. A., and Stainforth, R., 1947. A new genus and some new species of foraminifera from the Upper Eocene of Ecuador. Contr. Cushman Lab. Foram. Res., 23:77-80.

Cushman, J. A., and Stevenson, F., 1948. A Miocene foraminiferal fauna from Ecuador. Contr. Cushman Lab. Foram. Res., 24:50-68.

Cushman, J. A., and Stone, B., 1947. An Eocene foraminiferal fauna from the Chira Shale of Peru. Cushman Lab. Foram. Res. Spec. Publ., 20:1-27.

1949a. Foraminifera from the Eocene, Chacra Formation, of Peru. Contr. Cushman Lab. Foram. Res., 25:49-58.

1949b. Foraminifera from the Eocene, Verdun Formation, of Peru. Contr. Cushman. Lab. Foram. Res., 25:73-84.

Douglas, R., 1973. Benthonic foraminiferal biostratigraphy in the central North Pacific, Leg 17, Deep Sea Drilling Project. In Winterer, E. L., Ewing, J. I., et al., Init. Repts. DSDP, 17: Washington (U.S. Govt. Printing Office), 607-694.

Fahrbach, E., Brockmann, C., Lostaunau, N., and Urquizo W., 1981. The northern Peruvian upwelling system during the ESACAN experiment. In Richards, F. A. (Ed.), Coastal Upwelling: Washington (Am. Geophys. Union), 134-145.

Gunther, E., 1936. A report on oceanographical investigations in Peru Coastal Current. Discovery Repts., 13:107-276.

Haller, C., 1980. Pliocene biostratigraphy of California. In Kleinpell, R., The Miocene Stratigraphy of California Revisited: Tulsa (Am. Assoc. Pet. Geol.), 183-341.

Hofker, J., 1956. Tertiary foraminifera of coastal Ecuador: Part II, Additional notes on the Eocene species. J. Paleontol., 30:891958.

Ingle, J. C., Jr., 1980. Cenozoic paleobathymetry and depositional history of selected sequences within the southern California continental borderland. Cushman Found. Foram. Res. Spec. Publ. 19:163-195.

Ingle, J. C., Jr., and Keller, G., 1980. Benthic foraminiferal biofacies of the eastern Pacific margin between $40^{\circ} \mathrm{S}$ and $32^{\circ} \mathrm{N}$. Pacific Coast Paleogeography, Symp. 4. Soc. Econ. Paleontol. Mineral., 341355.

Ingle, J. C., Jr., Keller, G., and Kolpack, R. L., 1980. Benthic foraminiferal biofacies, sediments and water masses of the southern Peru-Chile Trench area, southeastern Pacific Ocean. Micropaleontology, 26:113-150.
Khusid, T. A., 1984. On dissolution of carbonate tests of benthic foraminifera on the Pacific shelf of South America. Oceanology, 24:85-91.

Kleinpell, R., 1938. Miocene Stratigraphy of California: Tulsa (Am. Assoc. Pet. Geol.).

1980. The Miocene Stratigraphy of California Revisited: Tulsa (Am. Assoc. Pet. Geol.), 1-182.

Loeblich, A. R., and Tappan, H., 1987. Foraminiferal Genera and Their Classification: New York (Van Nostrand).

Manheim, F., Rowe, G., and Jipa, D., 1975. Marine phosphorite formation off Peru. J. Sediment. Petrol., 45:243-251.

McCulloch, I., 1977. Qualitative Observations on Recent Foraminiferal Tests with Emphasis on The Eastern Pacific, Parts I-III: Los Angeles (University of Southern California).

Natland, M., 1950. 1940 E.W. Scripps cruise to the Gulf of California. Part IV-Report on the Pleistocene and Pliocene foraminifera. Geol. Soc. Am. Mem., 43:1-55.

Orbigny, A. d', 1839. Foraminiféres, Voyage dans l'Amèrique Meridionale: Paris (Pitois-Levrault et $\mathrm{C}$ ).

Parker, F., 1964. Foraminifera from the experimental mohole drilling near Guadalupe Island, Mexico. J. Paleontol., 38:617-636.

Phleger, F., and Soutar, A., 1973. Production of benthic foraminifera in three east Pacific oxygen minima. Micropaleontology, 19:110-115.

Renz, H., 1948. Stratigraphy and fauna of the Agua Salada group, State of Falcon, Venezuela. Geol. Soc. Am. Mem., 32:1-219.

Resig, J., 1981. Biogeography of benthic foraminifera of the northern Nazca plate and adjacent continental margin. Geol. Soc. Am. Mem., 154:619-666.

Rojas de Mendiola B., 1981. Seasonal phytoplankton distribution along the Peruvian coast. In Richards, F. A. (Ed.), Coastal Upwelling: Washington (Am. Geophys. Union), 348-356.

Rosato, V. J., Kulm, L. D., and Derks, P. S., 1975. Surface sediments of the Nazca plate. Pacific Sci., 29:117-130.

Rowe, G. T., 1981. The benthic processes of coastal upwelling ecosystems. In Richards, F. A. (Ed.), Coastal Upwelling: Washington (Am. Geophys. Union), 464-471.

Schuette, G., and Schrader, H., 1981. Diatoms in surface sediments: a reflection of coastal upwelling. In Richards, F. A. (Ed.), Coastal Upwelling: Washington (Am. Geophys. Union), 372-380.

Smith, P., 1963. Quantitative and qualitative analysis of the Family Bolivinidae. U.S. Geol. Surv. Prof. Pap., 429-A:1-39.

1964. Ecology of benthonic species. U.S. Geol. Surv. Prof. Pap., 492-B:1-55.

Stainforth, R., 1948. Applied micropaleontology in coastal Ecuador. J. Paleontol., 22:113-151.

Suess, E., von Huene, R., et al., 1988. Proc. ODP, Init. Repts., 112: College Station, TX (Ocean Drilling Program).

Todd, R., and Kniker, H., 1952. An Eocene foraminiferal fauna from the Agua Fresca Shale of Magallanes Province, southernmost Chile. Cushman Found. Foram. Res. Spec. Publ., 1:1-28.

Uchio, T., 1960. Ecology of living benthonic foraminifera from the San Diego, California area. Cushman Found. Foram. Res. Spec. Publ., 5:1-72.

Wyrtki, K., 1964. The thermal structure of the eastern Pacific Ocean. Deut. Hydrogr. Z. Ergaenzunqsh. A, 6:1-84.

1966. Oceanography of the eastern eguatorial Pacific Ocean. Oceanogr. Mar. Biol., Annu. Rev., 4:33-68.

1967. Circulation and water masses in the eastern eguatorial Pacific Ocean. Int. J. Oceanol. Limnol., 1:117-147.

Zen, E-An, 1959. Mineralogy and petrology of marine bottom sediment samples of the coast of Peru and Chile. J. Sediment. Petrol., 29:513-539.

Date of initial receipt: 12 January 1989

Date of acceptance: 3 August 1989

Ms 112B-186

\section{APPENDIX}

The American Museum of Natural History's Catalogue of Foraminifera contains type references for the species cited in this study. Listed below are only the species that have undergone taxonomic changes, and the original names under which they are catalogued. 
Alabamina atlantisae $($ Cushman $)=$ Pulvinulinella atlantisae

Ambitropus thalmanni (Stainforth and Stevenson) $=$ Palmerinella thalmanni

Amiphimorphina stainforthi $($ Cushman and Renz $)=$ Nodosaria stainforthi

Angulogerina angulosa (Williamson) $=$ Uvigerina angulosa

Anomalinoides alazanensis (Nuttall) = Anomalina alazanensis

Anomalinoides mantaensis (Galloway and Morrey) = Anomalina mantaensis

Anomalinoides pompilioides (Galloway and Hemingway) = Anomalina pompilioides

Astrononion schwageri $($ Cushman $)=$ Nonion schwageri

Bolivinellina basisenta (Cushman and Stone) $=$ Bolivina basisenta

Bolivinellina californica (Cushman) = Bolivina californica

Bolivinellina cuneata (Kleinpell) = Bolivina tumida cuneata

Bolivinellina ecuadorana (Cushman and Stevenson) = Bolivina ecua dorana

Bolivinellina foraminata (R.E. and K.C. Stewart) $=$ Bolivina seminuda foraminata

Bolivinellina goudkoffi (Rankin) = Bolivina goudkoffi

Bolivinellina humilis (Cushman and McCulloch) = Bolivina seminuda humilis

Bolivinellina pacifica (Cushman and McCulloch) = Bolivina acerosa pacifica

Bolivinellina quadrata (Cushman and McCulloch) $=$ Bolivina quadrata

Bolivinellina rankini (Kleinpell) = Bolivina rankini

Bolivinellina seminuda $($ Cushman $)=$ Bolivina seminuda

Bolivinita minuta $($ Natland $)=$ Bolivina minuta

Brizalina cf. acutula (Bandy) = Bolivina advena acutula

Brizalina argentea $($ Cushman $)=$ Bolivina argentea

Brizalina girardensis (Rankin) = Bolivina girardensis

Brizalina $\mathrm{cf}$. gladius (Garrett) $=$ Bolivina gladius

Brizalina imbricata (Cushman) = Bolivina imbricata

Brizalina interjuncta $($ Cushman $)=$ Bolivina costata interjuncta

Brizalina interjuncta bicostata (Cushman) = Bolivina costata bicostata

Brizalina cf. jacksonensis (Cushman and Applin) = Bolivina jacksonensis

Brizalina mantaensis $($ Cushman $)=$ Bolivina mantaensis

Brizalina pisciformis (Galloway and Morrey) = Bolivina pisciformis

Brizalina pseudobeyrichi $($ Cushman $)=$ Bolivina pseudobeyrichi

Brizalina spissa $($ Cushman $)=$ Bolivina subadvena spissa

Buccella oregonensis (Cushman, Stewart, and Stewart) = Eponides mansfieldi oregonensis

Buccella peruviana (d'Orbigny) = Rotalina peruviana

Bulimina alligata Cushman and Laiming = Bulimina inflata alligata

Bulimina exilis tenuata $($ Cushman $)=$ Buliminella subfusiformis tenuata

Bulimina hebespinata (R.E. and K.C. Stewart) = Bulimina pagoda hebespinata

Bulimina striata mexicana $($ Cushman $)=$ Bulimina inflata mexicana

Buliminella elegantissima (d'Orbigny) = Bulimina elegantissima

Cancris auricula (Fichtel and Moll) $=$ Nautilus auricula

Cancris inflatus (d'Orbigny) $=$ Valvulina inflata

Cassidelina complanata (Egger) = Virgulina schreibersiana complanata

Cassidelina nodosa (R.E. and K.C. Stewart) = Virgulina nodosa

Cassidulinoides bradyi $($ Norman $)=$ Cassidulina bradyi

Chilostomella serrata (Cushman and Stone $)=$ Chilostomella ovoidea serrata

Cibicidoides cicatricosus (Schwager) $=$ Anomalina cicatricosa

Cibicidoides compressus (Cushman and Renz) = Cibicides floridanus compressa

Cibicidoides cf. grimsdale $($ Nuttall) $=$ Cibicides grimsdale $i$

Cibicidoides cf. havanensis (Cushman and Bermudez) = Cibicides havanensis

Cibicidoides kullenbergi $($ Parker) $=$ Cibicides kullenbergi

Cibicidoides martinezensis (Cushman and Barksdale) $=$ Cibicides martinezensis

Cibicidoides mundula (Brady, Parker and Jones) $=$ Truncatulina mundula

Cibicidoides perlucidus $($ Nuttall $)=$ Cibicides perlucidus
Cibicidoides cf. pseudoungerianus (Cushman) $=$ Truncatulina pseudoungeriana

Cibicidoides trinitatensis $($ Nuttall $)=$ Truncatulina trinitatensis

Cribromiliolinella subvalvularis $(\mathrm{Parr})=$ Triloculina subvalvularis

Dorothia asiphonia (Andreae) = Gaudryina siphonella asiphonia

Eggerella bradyi (Cushman) = Verneuilina bradyi

Ehrenbergina trigona $($ Goes) = Ehrenbergina serrata trigona

Eilohedra levicula (Resig) = Epistominella levicula

Epistominella pacifica (Cushman) = Pulvinulinella pacifica

Epistominella smithi (R.E. and K.C. Stewart) $=$ Pulvinulinella smithi

Fontbotia wuellerstorfi (Schwager) = Anomalina wuellerstorfi

Fursenkoina bramlettei (Galloway and Morrey) $=$ Virgulina bramlet tei

Fursenkoina californiensis (Cushman) = Virgulina californiensis

Fursenkoina glabra (Cushman and Wickenden $)=$ Bulimina patagonica glabra

Fursenkoina nuda (of Hofker, 1956), not Buliminella basistriata nuda (Howe and Wallace)

Fursenkoina restinensis (Berry) $=$ Bolivina restinensis

Galliherina cf. delreyensis (Cushman and Galliher) = Bulimina delreyensis

Galliherina uvigerinaformis (Cushman and Kleinpell) $=$ Bulimina uvigerinaformis

Galliherina uvigerinaformis charapotoensis (Cushman and Stevenson) = Bulimina uvigerinaformis charapotoensis

Glandulina laevigata (d'Orbigny) $=$ Nodosaria (Glandulina) laevigata

Globobulimina affinis (d'Orbigny) $=$ Bulimina affinis

Globobulimina diversa (Cushman and Stone) $=$ Bulimina $($ Desinobulimina) diversa

Globobulimina ovula (d'Orbigny) = Bulimina ovula

Globobulimina pseudovata (Hofker) = Bulimina pseudovata

Globocassidulina crassa (d'Orbigny) = Cassidulina crassa

Globocassidulina depressa (Asano and Nakamura) = Cassidulina subglobosa depressa

Globocassidulina globosa (Hantken) = Cassidulina globosa

Globocassidulina cf. lomitensis (Galloway and Wissler) = Cassidulina lomitensis

Globocassidulina quadrata (Cushman and Hughes) $=$ Cassidulina subglobosa quadrata

Globocassidulina sublaevigata (Hofker) = Cassidulina sublaevigata

Globocassidulina subglobosa (Brady) = Cassidulina subglobosa

Globocassidulina subglobosa horizontalis (Cushman and Renz) = Cassidulina subglobosa horizontalis

Guttulina irregularis (d'Orbigny) = Globulina irregularis

Gyroidina octocamerata $($ Cushman and Hanna $)=$ Gyroidina soldanii octocamerata

Gyroidina perampla (Cushman and Stewart) $=$ Gyroidina girardana perampla

Gyroidina turgida (Phleger and Parker) = Eponides turgidus

Hansenisca altiformis (R.E. and K.C. Stewart) $=$ Gyroidina soldanii altiformis

Hansenisca multilocula $($ Coryell and Mossman $)=$ Gyroidina soldanii multilocula

Hansenisca soldanii (d'Orbigny) $=$ Gyroidina soldanii

Hansenisca zealandica (Finlay) = Gyroidina zealandica

Hanzawaia cf. mantaensis (Galloway and Morrey) = Anomalina mantaensis

Hanzawaia nitidula (Bandy) = Cibicidina basiloba nitidula

Heterolepa? crebbsi (Hedberg) $=$ Eponides crebbsi

Hoeglundina elegans (d'Orbigny) = Rotalia elegans

Hofkerina smithi (Kleinpell) = Siphogenerina smithi

Holmanella cf. valmonteensis (Kleinpell) = Discorbinella valmonteensis

Hopkinsina $\mathrm{cf}$. danvillensis $($ Howe and Wallace $)=U$ vigerina danvillensis

Karreriella bradyi (Cushman) = Gaudryina bradyi

Laticarinina pauperata (Parker and Jones) = Pulvinulina repanda menardii pauperata

Lenticulina subpapillosa (Nuttall) = Cristellaria subpapillosa

Martinottiella communis (d'Orbigny) $=$ Clavulina communis 


\section{J. M. RESIG}

Martinottiella cyclostomata (Galloway and Morrey) = Verneuilina cyclostomata

Martinottiella nodulos (Cushman $)=$ Clavulina communis nodulosa Melonis affinis (Reuss) $=$ Nonionina affinis

Melonis pompilioides (Fichtel and Moll) $=$ Nautilus pompilioides

Nodogenerina spinea $($ Cushman) = Ellipsonodosaria curvatura spinea

Nodosaria aff. consobrina (d'Orbigny) = Dentalina consobrina

Nonionella auris (d'Orbigny) = Valvulina auris

Nonionoides basispinatus $($ Cushman and Moyer) $=$ Nonion pizarrense basispinata

Nuttallides cf. decorata (Phleger and Parker) = Pseudoparrella decorata

Nuttallides truempyi $($ Nuttall $)=$ Eponides truempyi

Oridorsalis umbonatus (Reuss) $=$ Rotalia umbonata

Osangularia culter (Parker and Jones) $=$ Planorbulina culter

Parrelloides bradyi $($ Trauth $)=$ Truncatulina bradyi

Planulina depressa (d'Orbigny) $=$ Truncatulina depressa

Planulina ornata (d'Orbigny) $=$ Truncatulina ornata

Praeglobobulimina spinescens $($ Brady $)=$ Bulimina pyrula spinescens

Proxifrons advena $($ Cushman $)=$ Frondicularia advena

Pseudoparrella exigua $($ Brady $)=$ Pulvinulinella exigua

Pseudoparrella obesa $($ Bandy and Arnal $)=$ Epistominella obesa

Pseudoparrella sandiegoensis $(\mathrm{Uchio})=$ Epistominella sandiegoensis

Pseudoparrella subperuviana $($ Cushman $)=$ Pulvinulinella subperuviana

Pullenia bulloides (d'Orbigny) $=$ Nonionina bulloides

Pullenia quinqueloba (Reuss) = Nonionina quinqueloba

Pullenia subcarinata (d'Orbigny) $=$ Nonionina subcarinata

Pyrgo murrhyna $($ Schwager $)=$ Biloculina murrhina

Pyrgo serrata (Bailey) = Biloculina serrata

Rectuvigerina $\mathrm{cf}$. multicostata (Cushman and Jarvis) = Siphogenerina multicostata

Robulus cf. americanus (Cushman) $=$ Cristellaria americana

Robulus aff. brevispinosus (Nuttall) $=$ Cristellaria brevispinosa

Rotorbinella garveyensis $($ Natland) $=$ Rotalia garveyensis

Rutherfordoides cornutus $($ Cushman $)=$ Virgulina cornuta

Sigmoilopsis schlumbergeri $($ Silvestri) $=$ Sigmoilina schlumbergeri

Siphonodosaria paucistriata (Galloway and Morrey) $=$ Nodosarella paucistriata

Stilostomella fistuca $($ Schwager $)=$ Nodosaria fistuca

Takayanagia asanoi $($ Uchio) $=$ Cassidulina asanoi

Takayanagia delicata $($ Cushman $)=$ Cassidulina delicata

Valvulineria depressa $($ Cushman $)=$ Valvulineria miocenica depressa

Valvulineria glabra $($ Cushman $)=$ Valvulineria vilardeboana glabra

Valvulineria inaequalis (d'Orbigny) = Valvulina inaequalis

Valvulineria rugosa minuta $($ Schubert $)=$ Dicorbina rugosa minuta

Zeaflorilus chiliensis $($ Cushman and Kellett $)=$ Nonionella chiliensis
Table 7. Percentage of species representation, ODP Holes 683A and 683B (3071 m).

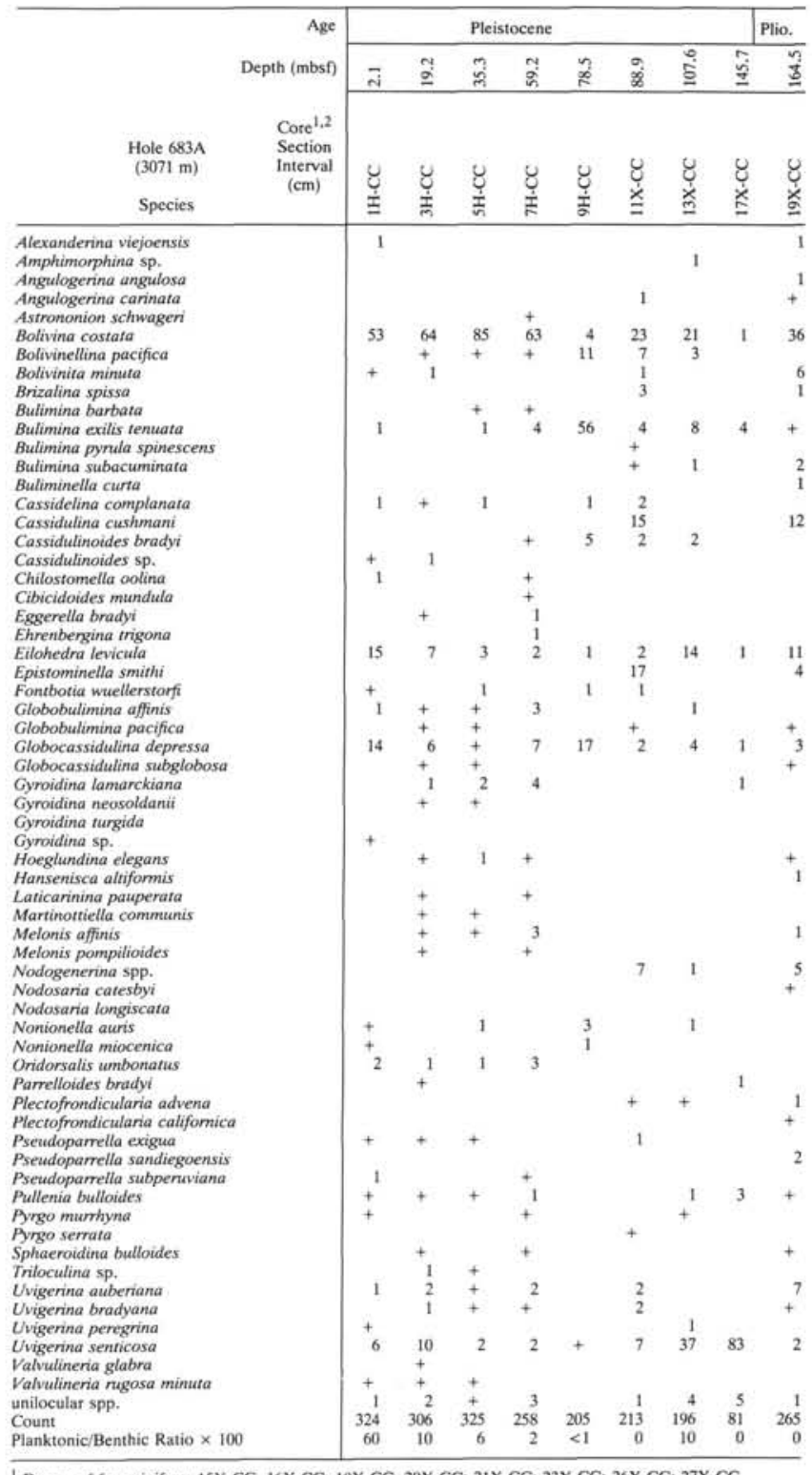

1 Barren of foraminifers: $15 X-C C ; 16 X-C C ; 18 X-C C ; 20 X-C C ; 21 X-C C ; 23 X-C C ; 26 X-C C ; 27 X-C C$.
2 Counts less than $80 ; 22 X-C C ; 24 X-C C ; 25 X-C C$. 
Table 7 (continued).

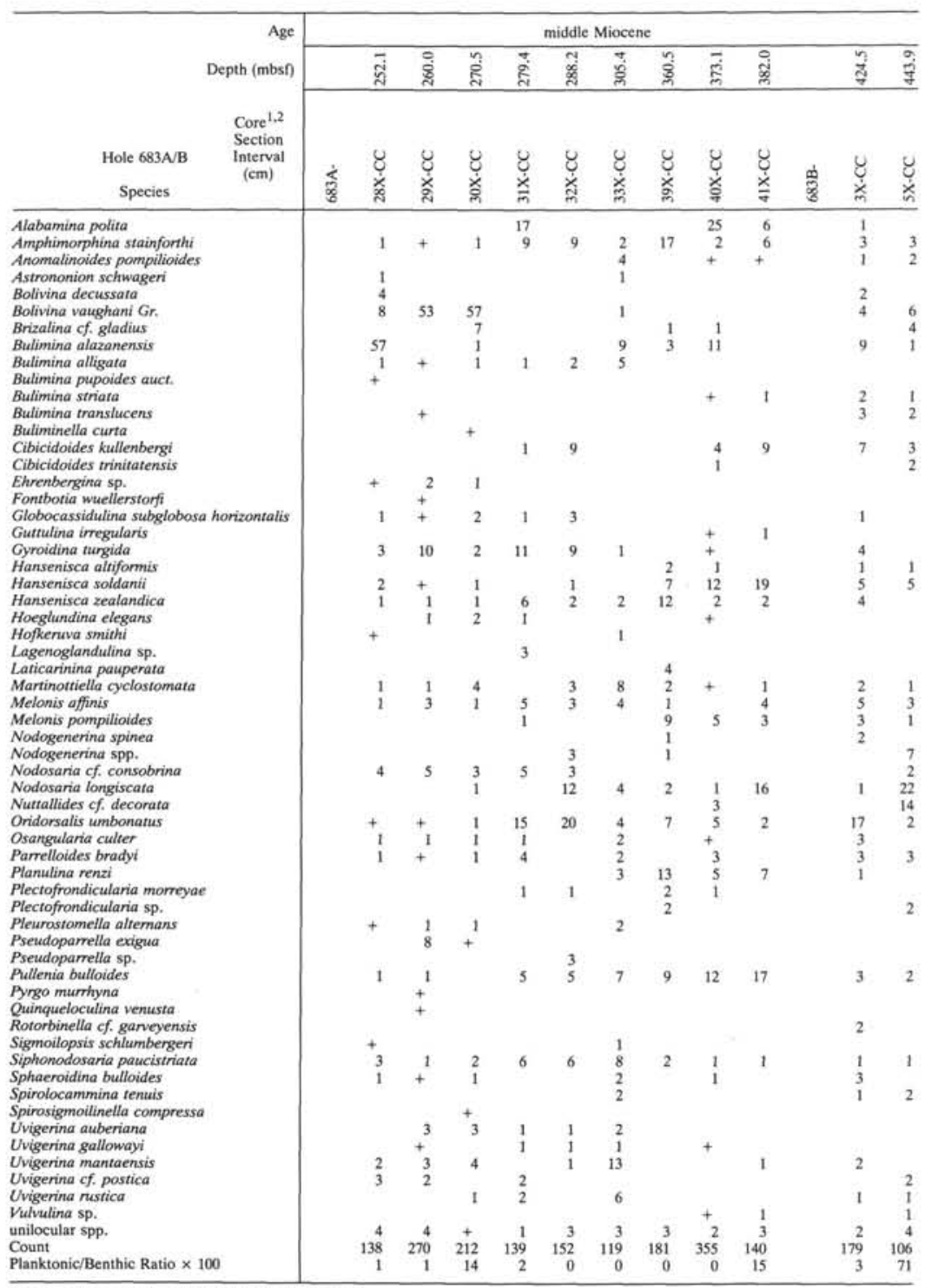

1 Barren of foraminifers: $34 \mathrm{X}-\mathrm{CC} ; 35 \mathrm{X}-\mathrm{CC} ; 44 \mathrm{X}-\mathrm{CC}$

${ }^{2}$ Counts less than 100: $36 \mathrm{X}-\mathrm{CC}$; $37 \mathrm{X}-\mathrm{CC}$; $38 \mathrm{X}-\mathrm{CC} ; 42 \mathrm{X}-\mathrm{CC} ; 43 \mathrm{X}-\mathrm{CC} ; 45 \mathrm{X}-\mathrm{CC}$, 
Table 7 (continued).

\begin{tabular}{|c|c|c|c|c|}
\hline \multirow{2}{*}{ Depth (mbsf) } & \multicolumn{4}{|c|}{ middle Eocene } \\
\hline & $\begin{array}{l}\infty \\
\text { ș }\end{array}$ & ì & $\stackrel{8}{6}$ & $\underset{\forall}{\alpha}$ \\
\hline $\begin{array}{c}\text { Core }^{1.2} \\
\text { Section } \\
\text { Interval } \\
(\mathrm{cm})\end{array}$ & $\begin{array}{l}\dot{2} \\
\dot{a} \\
\dot{b} \\
\dot{x}\end{array}$ & $\underset{\dot{x}}{\ddot{x}}$ & $\begin{array}{l}\underset{x}{x} \\
\dot{x}\end{array}$ & $\begin{array}{l}\ddot{\forall} \\
\ddot{\sigma}\end{array}$ \\
\hline Alabamina atlantisae & 4 & & 3 & \\
\hline $\begin{array}{l}\text { Anomalina chirana } \\
\text { Anomalinoides mantaensis }\end{array}$ & & & & + \\
\hline $\begin{array}{l}\text { Anomialinoldes mantaensis } \\
\text { Asterigerina crassaformis }\end{array}$ & 1 & + & 4 & \\
\hline $\begin{array}{l}\text { Bathysiphon eocenica } \\
\text { Bolivina chirana }\end{array}$ & & + & & + \\
\hline Bolivina cf. ignara & & & 1 & \\
\hline Bolivina maculata & 6 & + & 1 & \\
\hline Bolivinellina basisenta & 10 & 17 & & \\
\hline $\begin{array}{l}\text { Bolivinellina sp. } \\
\text { Brizalina of. jacksonensis }\end{array}$ & 4 & 5 & $\frac{1}{7}$ & \\
\hline $\begin{array}{l}\text { Bulimina chirana } \\
\text { and }\end{array}$ & 3 & 9 & 9 & 14 \\
\hline Bulimina peruviana & + & + & 1 & \\
\hline Bulimina stalacta & & 1 & & \\
\hline $\begin{array}{l}\text { Bulimina truncanella } \\
\text { Buliminella chirana }\end{array}$ & $\begin{array}{l}6 \\
1\end{array}$ & & & \\
\hline Buliminella pernviana & II & 21 & 24 & \\
\hline Buliminellita minfica & 26 & 17 & & \\
\hline Chilostomella serrata & & + & & \\
\hline Cibicides of. martinezensis & & + & & \\
\hline Cibicidoides of. grimsdalei & & & 1 & \\
\hline Cibicidoides of. havanensis & & & 1 & \\
\hline & & 3 & & \\
\hline Cyclammina simiensis & & + & & \\
\hline $\begin{array}{l}\text { Dorothia principensis } \\
\text { Eponides cf. minimus }\end{array}$ & & + & 6 & \\
\hline Fursenkoina sp. & & & 16 & \\
\hline Glandulina laevigata & & + & & + \\
\hline Globobulimina cf. oregonensis & & & 9 & \\
\hline $\begin{array}{l}\text { Globobulimina pseudovata } \\
\text { Globocassidulina globosa }\end{array}$ & 7 & $i$ & 1 & \\
\hline $\begin{array}{l}\text { Globocassidulina globosa } \\
\text { Globocassidulina subglobosa }\end{array}$ & 1 & + & & \\
\hline Globocassidulina sp. & 2 & & & \\
\hline $\begin{array}{l}\text { Gyroidina octocamerata } \\
\text { Hopkinsing of donvillensi }\end{array}$ & 1 & 3 & & + \\
\hline $\begin{array}{l}\text { Hopkinsina cf. danvillt } \\
\text { Nodogenerina sp. }\end{array}$ & 4 & 1 & & \\
\hline Nodosaria langiscata & 5 & + & & \\
\hline Nuttallides iniempyi & & + & & \\
\hline Oridorsalis umbonatus & + & & & \\
\hline Parrelloides bradyi & & & & \\
\hline Plectofrondicularia volkesi & & + & & \\
\hline $\begin{array}{l}\text { Pleurostomella sp. } \\
\text { Pullenia duplicata }\end{array}$ & & & 3 & \\
\hline $\begin{array}{l}\text { Pullenia duplicata } \\
\text { Quinqueloculina cf. naheolensis }\end{array}$ & + & + & & \\
\hline Robulus spp. & 2 & & 1 & \\
\hline dina thalmanni & 5 & 15 & & 2 \\
\hline ecuadorensis & 1 & 4 & 1 & \\
\hline Vaginulina sp. & & & 1 & \\
\hline $\begin{array}{l}\text { Valvulineria welcomensis } \\
\text { unilocular spp. }\end{array}$ & & + & & 10 \\
\hline $\begin{array}{l}\text { unilocular spp. } \\
\text { Count }\end{array}$ & 499 & 1312 & $\begin{array}{r}1 \\
138\end{array}$ & 291 \\
\hline Planktonic/Benthic Ratio $\times 100$ & 30 & 5 & 66 & \\
\hline
\end{tabular}

${ }^{1}$ Counts less than 100: 8X-1, 32-35.
Table 8. Pecentage of species representation, Hole 682A (3789 m),

\begin{tabular}{|c|c|c|c|c|c|c|c|}
\hline \multirow{2}{*}{ Depth (mbsf) } & \multicolumn{5}{|c|}{ Quat. } & \multicolumn{2}{|c|}{ 1. Plio. } \\
\hline & $\ddot{m}$ & $\hat{a}$ & $\stackrel{g}{\dot{I}}$ & $\begin{array}{l}\infty \\
\infty \\
\infty\end{array}$ & $\stackrel{\leftrightarrow}{\dot{n}}$ & ñ & हิ \\
\hline $\begin{array}{c}\text { Hole } 682 \mathrm{~A} \\
(3789 \mathrm{~m}) \\
\text { Species }\end{array}$ & $\begin{array}{l}\frac{2}{2} \\
\stackrel{m}{ \pm}\end{array}$ & $\begin{array}{l}\underset{1}{\Xi} \\
\end{array}$ & $\begin{array}{l}\infty \\
\stackrel{0}{ } \\
\check{n} \\
\dot{+} \\
\dot{\sim}\end{array}$ & $\frac{\text { U্ }}{\dot{\lambda}}$ & 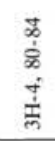 & 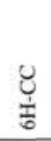 & 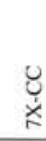 \\
\hline Astrononion schwageri & & & 2 & 8 & + & & \\
\hline Bolivina costata & 27 & 16 & 24 & 12 & 9 & 4 & 14 \\
\hline Bolivinellina humilis & 5 & & & + & & & \\
\hline Bolivinellina pacifica & 2 & & + & + & + & & \\
\hline Bolivinita minuta & 1 & & + & 1 & & & \\
\hline Bulimina alazanensis & & & + & + & 1 & & \\
\hline Bulimina exilis tenuata & & & & & & 13 & \\
\hline Bulimina striata mexicana & & & & & & + & \\
\hline Buliminella curta & 4 & & & + & & & \\
\hline Buliminella elegantissima limbosa & 4 & + & & + & 1 & & \\
\hline Cassidelina complanata & 1 & + & 1 & 1 & 3 & & 2 \\
\hline Cassidulina cushmani & 2 & & & & & & \\
\hline Cassidulinoides bradyi & & & & 2 & 1 & 2 & \\
\hline Eggerella bradyi & & & 3 & 1 & 1 & & \\
\hline Ehrenbergina trigona & & & 11 & 4 & 9 & & \\
\hline Eilohedra levicula & 2 & 10 & 19 & 5 & 7 & 39 & 29 \\
\hline Epistominella smithi & & & & & 1 & & \\
\hline Eponides tumidulus & & & 2 & 2 & 2 & & \\
\hline Fontbotia wuellerstorfi & + & + & & + & 1 & 1 & \\
\hline Fursenkoina glabra & & & & & 1 & & \\
\hline $\begin{array}{l}\text { Globobulimina affinis } \\
\text { Globobulimina pacifica }\end{array}$ & + & & + & + & & 1 & \\
\hline Globocassidulina depressa & & 31 & 3 & 4 & 3 & 17 & 4 \\
\hline Globocassidulina subglobosa & + & 2 & 1 & 1 & 5 & & \\
\hline Gyroidina lamarckiana & 2 & 1 & 4 & 1 & 7 & 8 & \\
\hline Gyroidina turgida & 5 & & & & & & \\
\hline Hansenisca altiformis & & & & + & & 1 & \\
\hline Hoeglundina elegans & 2 & & & + & 1 & & \\
\hline Martinottiella communis & & & + & + & & + & 1 \\
\hline Melonis affinis & & 1 & 3 & + & 2 & & + \\
\hline Melonis pompilioides & 1 & 2 & & & & & \\
\hline $\begin{array}{l}\text { Nodogenerina sp. } \\
\text { Nodosaria calomorpha }\end{array}$ & & & + & & & + & 1 \\
\hline Nodosaria consobrina & & & & & & 1 & 3 \\
\hline Nodosaria longiscata & & & & & & 3 & 34 \\
\hline Nonionella auris & + & + & & & 3 & & \\
\hline Oridorsalis umbonatus & 2 & 2 & 2 & + & 5 & & \\
\hline Parrelloides bradyi & & & + & + & & & \\
\hline Plectofrondicularia spp. & & & & + & & & \\
\hline Pleurostomella altermans & & & & + & & & 1 \\
\hline Pseudoparrella exigua & 26 & + & 7 & 49 & 1 & & \\
\hline Pseudoparrella subperuviana & 9 & & & & & & \\
\hline Pullenia bulloides & + & 3 & 1 & + & 1 & & \\
\hline Pullenia quinqueloba & 2 & 2 & 3 & 1 & + & 2 & 1 \\
\hline Pyngo murrhyna & + & + & + & + & 1 & & \\
\hline Robulus sp. & & & & & & + & \\
\hline Sphaeroidina bulloides & & & 1 & & & 4 & 1 \\
\hline Spirolocammina tenuis & & & & + & 2 & & \\
\hline Stilostomella fistuca & & & & & & & 1 \\
\hline Triloculina trigonula & & & & & & & 1 \\
\hline Triloculina sp. & 2 & & & & & & \\
\hline Uvigerina auberiana & & 1 & 3 & 4 & & 1 & 4 \\
\hline Uvigerina senticosa & + & 25 & 2 & 2 & 6 & 1 & \\
\hline unilocular spp. & 1 & 5 & 5 & 1 & 3 & 2 & \\
\hline Count & 125 & 183 & 582 & 615 & 106 & 144 & 139 \\
\hline Planktonic/Benthic Ratio $\times 100$ & 61 & 15 & 2 & 15 & 611 & 0 & 22 \\
\hline
\end{tabular}

${ }^{1}$ Barren of foraminifers: $3 \mathrm{H}-\mathrm{CC} ; 4 \mathrm{H}-3$ (71-75); $4 \mathrm{H}-\mathrm{CC}$.

2 Counts less than 100: $5 \mathrm{X}$-CC. 
Table 8 (continued).

\begin{tabular}{|c|c|c|c|c|c|c|c|c|c|c|c|c|c|c|c|c|c|}
\hline \multirow{2}{*}{\multicolumn{2}{|c|}{$\begin{array}{r}\text { Age } \\
\text { Depth (mbsf) }\end{array}$}} & \multirow{2}{*}{$\frac{\text { e. Plio. }}{\frac{m}{6}}$} & \multicolumn{11}{|c|}{ late Miocene } & \multicolumn{3}{|c|}{ m. Mio. } & \multirow{2}{*}{$\frac{\text { e. Mi }}{\text { ڤุ }}$} \\
\hline & & & $\tilde{F}$ & ङे & $\overline{\vec{\Xi}}$ & $\stackrel{\infty}{\kappa}$ & $\stackrel{?}{3}$ & $\stackrel{9}{E}$ & $\stackrel{m}{\infty}$ & हूं & กั่ & กี่ & ஷें & के & $\frac{9}{2}$ & कें & \\
\hline $\begin{array}{c}\text { Hole } 682 \mathrm{~A} \\
\text { Species }\end{array}$ & $\begin{array}{l}\text { Core } \\
\text { Section } \\
\text { Interval } \\
\quad(\mathrm{cm})\end{array}$ & $\underset{\infty}{\dot{\leftrightarrow}}$ & ச্ّ & $\begin{array}{l}\dot{y} \\
\dot{x} \\
\underline{\Xi}\end{array}$ & 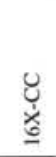 & 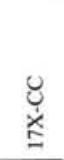 & $\begin{array}{l}\underset{\dot{x}}{x} \\
\stackrel{\infty}{\infty}\end{array}$ & $\begin{array}{l}\dot{U} \\
\dot{x} \\
\stackrel{\Xi}{\varrho}\end{array}$ & $\begin{array}{l}\ddot{U} \\
\dot{x} \\
\ddot{̃}\end{array}$ & ্்ְ & 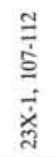 & 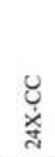 & \begin{tabular}{l}
$u$ \\
$\dot{x}$ \\
$x$ \\
\cline { 1 - 1 }
\end{tabular} & U্ণ & 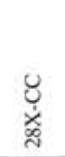 & 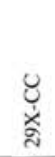 & 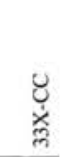 \\
\hline $\begin{array}{l}\text { Ambitropus thalmanni } \\
\text { Amphimorphina stainforthi }\end{array}$ & & & & & 22 & + & 4 & 1 & + & t & 1 & & 2 & 2 & + & 0 & 3 \\
\hline $\begin{array}{l}\text { Amphimorphina stainforthi } \\
\text { Amphimorphina sp. }\end{array}$ & & & & & & & $\begin{array}{r}10 \\
5\end{array}$ & + & 38 & + & 1 & & 1 & + & + & 9 & $\begin{array}{l}3 \\
1\end{array}$ \\
\hline $\begin{array}{l}\text { Anomalinoides sp. } \\
\text { Bolivina costata }\end{array}$ & & $\begin{array}{l}2 \\
2\end{array}$ & 1 & & 1 & & & & & & & & & & & & \\
\hline Bolivina decussata & & & & 1 & + & + & & & & & & & & & & & \\
\hline Bolivina granti & & + & & 6 & & & & & & & & & & & & & \\
\hline Bolivina sinuata & & + & & & & 5 & 2 & 1 & & & 1 & 2 & 5 & 1 & & & \\
\hline Bolivina sinuata alisoensis & & & & 1 & & & & & & & & & & & & & \\
\hline $\begin{array}{l}\text { Bolivina vaughani } \\
\text { Bolivinellina califormica }\end{array}$ & & 2 & & 3 & 12 & 1 & 1 & 26 & 7 & 4 & 1 & 1 & & + & 8 & & \\
\hline Bolivinellina ecuadorana & & & & & & + & 6 & 11 & 1 & 1 & 1 & & & & + & & \\
\hline Bolivinellina foraminata & & & & & 5 & & & & & & & & & & & & \\
\hline Bolivinellina girardensis & & 40 & & & & & & & & & & & & & & & \\
\hline Bolivinellina goudkoffi & & 14 & & & & & & & & & & & & & & & \\
\hline $\begin{array}{l}\text { Bolivinellina seminuda var. } \\
\text { Bolivinellina sp. }\end{array}$ & & & & 4 & 15 & + & & & 3 & 3 & 2 & & 1 & & + & + & \\
\hline Bolivinita minuta & & 4 & & & & & & & + & & & & & + & 3 & & \\
\hline Brizalina imbricata & & & & & & & & 3 & & + & & & & & & & \\
\hline Brizalina pisciformis & & & & & & & & 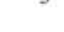 & & & & & 5 & 1 & + & 3 & 4 \\
\hline Buccella oregonensis & & & & & & + & + & + & & + & & & & & & & \\
\hline Bulimina alazanensis & & & & + & & & & & & & 1 & & 2 & 1 & & 2 & \\
\hline Bulimina alligata & & & & & & & & & & & 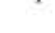 & & & 3 & + & 1 & 1 \\
\hline Bulimina elongata & & & & & & & & & & & & & & 1 & & 9 & \\
\hline Bulimina exilis tenuata & & 3 & & & & & & & & & & & & & & & \\
\hline Bulimina hebespinata & & & & & & & & + & & & + & 1 & 4 & & & & \\
\hline Buliminella curta & & 1 & & + & & & & & & & 21 & & 12 & 5 & 4 & 4 & 3 \\
\hline Buliminella elegantissima limbosa & & & & + & & 4 & 12 & 21 & 14 & 63 & 45 & 77 & 25 & 45 & 69 & 4 & \\
\hline Buliminella subfusiformis & & & & & 34 & 14 & 12 & 8 & 12 & & 27 & & 14 & 7 & & & \\
\hline Cassidulina cushmani & & 1 & & 1 & & 5 & 2 & 3 & 3 & + & 1 & 4 & & 2 & 2 & 1 & \\
\hline Cassidulinoides bradyi & & + & & & & & & & & & & & & & & & \\
\hline Cibicidoides compressus & & & & & & & & & & & & & & & & & 6 \\
\hline Eilohedra levicula & & 10 & 3 & 3 & 1 & 2 & & & & & & & & & & 5 & \\
\hline $\begin{array}{l}\text { Epistominella smithi } \\
\text { Fontbotia wuellerstorfi }\end{array}$ & & & & & 19 & 25 & 5 & 1 & 3 & 9 & 1 & 6 & 9 & 10 & 3 & 1 & \\
\hline $\begin{array}{l}\text { Fontbotia wuellerstorfi } \\
\text { Fursenkoina restinensis }\end{array}$ & & & & 2 & & & & & & & & & & + & & & \\
\hline $\begin{array}{l}\text { Galliherina uvigerinaformis } \\
\text { charapatoensis }\end{array}$ & & & & & & & & 3 & & & & & & & & & \\
\hline Globocassidulina subglobosa & & & & & & 1 & & & & & & & & & & 1 & \\
\hline Gyroidina lamarckiana & & 1 & 2 & & & & & & & & & & & & & i & \\
\hline Hansenisca altiformis & & & & & & & + & & 1 & 1 & 1 & & 4 & 2 & & & \\
\hline $\begin{array}{l}\text { Hansenisca multilocula } \\
\text { Hansenisca zealandica }\end{array}$ & & & & + & 3 & + & & & & & & & & & & & \\
\hline $\begin{array}{l}\text { Hansenisca zealandica } \\
\text { Holmanella cf. valmonteensis }\end{array}$ & & & & + & & & + & & & & & & & & & 1 & \\
\hline Lagenoglandulina sp. & & & 4 & & & + & & + & & & & & & & & & \\
\hline Melonis affinis & & & 1 & & & & & & & & & & & & & & \\
\hline Melonis pompilioides & & & 1 & & & & & & & & & & & & & & \\
\hline Nodogenerina sp. & & 2 & 4 & & & 1 & + & + & 1 & & & & & 2 & & 1 & \\
\hline Nodosaria consobrina & & 1 & 5 & + & & & & & & & & & & & & & \\
\hline Nodosaria longiscata & & & 43 & & & & & & & & & & + & & & & 10 \\
\hline Nonionella ecuadorana & & & & & & & & 1 & & & & & & & & & \\
\hline Oridorsalis umbonatus & & & & & & & & & & & & & 2 & + & & & 1 \\
\hline $\begin{array}{l}\text { Planulina ornata } \\
\text { Planulina renzi }\end{array}$ & & & & & & 1 & + & + & 4 & & & & & & & & 1 \\
\hline $\begin{array}{l}\text { Planulina renzi } \\
\text { Plectofrondicularia advena }\end{array}$ & & 1 & & & & & & & + & + & + & & & 2 & & & 2 \\
\hline Plectofrondicularia californica & & & & + & & 1 & + & + & & & & & & & & & 2 \\
\hline $\begin{array}{l}\text { Plectofrondicularia spp. } \\
\text { Pleurostomella altemans }\end{array}$ & & & $\begin{array}{l}5 \\
2\end{array}$ & & & + & & & & & & & & 3 & & & \\
\hline Pseudoparrella subpeniviana & & & 1 & 68 & 4 & 9 & 6 & 5 & 5 & 1 & 3 & & + & 2 & 4 & 24 & \\
\hline $\begin{array}{l}\text { Pullenia bulloides } \\
\text { Robulus } \mathrm{spp} \text {. }\end{array}$ & & + & 1 & 2 & + & & & & & & & & & & & & 1 \\
\hline Rotorbinella garveyensis & & & & 1 & & 4 & 2 & 1 & 2 & 1 & 2 & & 9 & 5 & & 5 & 1 \\
\hline Siphonodosaria paucistriata & & & & & & & & & & & & & & & & & 8 \\
\hline Sphaeroidina bulloides & & 3 & 6 & & & & & & & & & & & & & & \\
\hline Stilostomella fistuca & & & 4 & & & 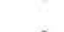 & & & & & & & & & & & \\
\hline $\begin{array}{l}\text { Uvigerina auberiana } \\
\text { Uvigerina gallowayi }\end{array}$ & & 12 & 14 & 3 & & 2 & & & 1 & & & & 2 & 2 & + & 6 & 5 \\
\hline Uvigerina hispido-costata & & & & & & & & & 4 & & 1 & & 7 & 4 & & 8 & 3 \\
\hline Uvigerina mantaensis & & & & 1 & & 24 & 4 & 1 & 1 & 1 & 1 & 1 & & & & 5 & 51 \\
\hline Uvigerina marksi & & & & 4 & 3 & & & $i$ & & + & & & + & & & & \\
\hline $\begin{array}{l}\text { Uvigerina peregrina + dinupta } \\
\text { Uvigerina mustica }\end{array}$ & & & & & & 3 & 3 & + & & & & & 4 & & & & 4 \\
\hline Valvulineria compressa & & & & & & 1 & 4 & 9 & 1 & & 2 & 1 & & 1 & 1 & & \\
\hline unilocular spp. & & & 4 & & & 1 & 2 & & & + & & 1 & + & & + & 1 & 1 \\
\hline Count & & 154 & 120 & 544 & 318 & 211 & 192 & 163 & 160 & 433 & 213 & 148 & 125 & 257 & 525 & 150 & 100 \\
\hline Planktonic/Benthic Ratio $\times 100$ & & 0 & $<1$ & $<1$ & $<1$ & 1 & 1 & 4 & 0 & 1 & $<1$ & 0 & 0 & $<1$ & $<1$ & 0 & 0 \\
\hline
\end{tabular}

1 Barren of foraminifers: 10X-CC; 11X-CC; $12 \mathrm{X}-\mathrm{CC}$; $13 \mathrm{X}-\mathrm{CC}$.

2 Counts less than 100: 14X-CC; 21 X-CC; $27 X-C C$. 
Table 8 (continued).

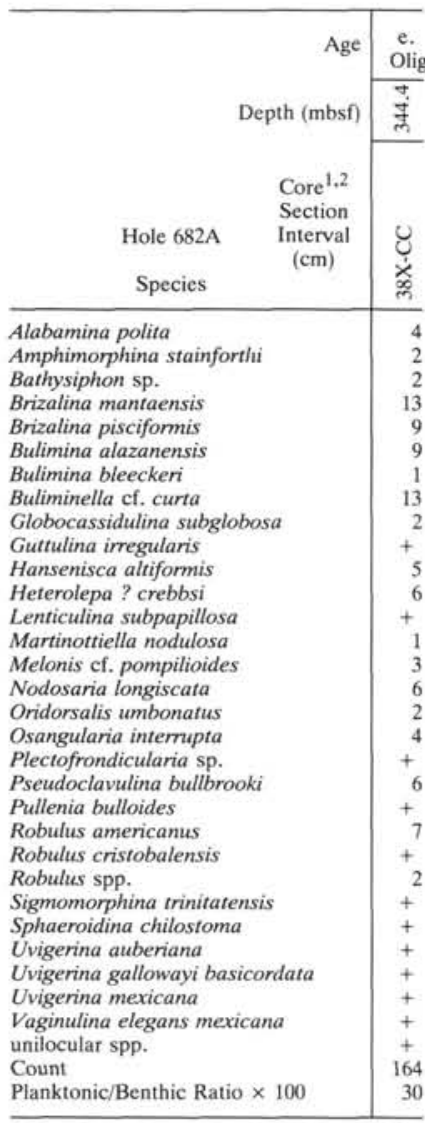

${ }^{1}$ Foraminifera in matrix: $41 \mathrm{X}-\mathrm{CC} ; 42 \mathrm{X}-\mathrm{CC}$. ${ }^{2}$ Counts less than 100: $34 \mathrm{X}-\mathrm{CC} ; 35 \mathrm{X}-\mathrm{CC}$ $36 \mathrm{X}-\mathrm{CC}$; 37X-CC; 39X-2, 41-43; 40X-2, 43 $47 ; 40 \mathrm{X}-\mathrm{CC}$
Table 8 (continued).

\begin{tabular}{|c|c|c|c|c|c|}
\hline \multirow{2}{*}{\multicolumn{2}{|c|}{$\begin{array}{r}\text { Age } \\
\text { Depth (mbsf) }\end{array}$}} & $\begin{array}{l}\text { e. } \\
\text { Olig. }\end{array}$ & & $\begin{array}{l}\text { middle } \\
\text { Eocen }\end{array}$ & \\
\hline & & $\overline{5}$ & $\stackrel{\circ}{\circ}$ & $\stackrel{4}{\frac{4}{4}}$ & 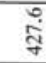 \\
\hline Hole $682 \mathrm{~A}$ & $\begin{array}{c}\text { Core }{ }^{1,2} \\
\text { Section } \\
\text { Interval } \\
\text { (cm) }\end{array}$ & 导 & 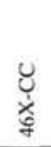 & $\underset{\substack{\dot{x} \\
\dot{\forall}}}{\dot{y}}$ & 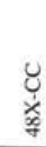 \\
\hline \multirow{2}{*}{\multicolumn{2}{|c|}{$\begin{array}{l}\text { Alabamina atlantisae } \\
\text { Amphimorphina stainforthi }\end{array}$}} & 3 & & & 4 \\
\hline & & & & 2 & + \\
\hline \multicolumn{2}{|c|}{$\begin{array}{l}\text { Anomalinoides alazanensis } \\
\text { Anomalinoides pompilioides }\end{array}$} & & 1 & 1 & \\
\hline \multirow{2}{*}{\multicolumn{2}{|c|}{$\begin{array}{l}\text { Anomalinoides pompilioides } \\
\text { Asterigerina crassaformis } \\
\text { Bathysiphon eocenica }\end{array}$}} & & + & 1 & \\
\hline & & & & i & 2 \\
\hline \multicolumn{2}{|l|}{ Bolivina maculata } & + & & & 1 \\
\hline \multirow{2}{*}{\multicolumn{2}{|c|}{$\begin{array}{l}\text { Bolivinellina basisenta } \\
\text { Brizalina sp. }\end{array}$}} & 17 & 25 & 20 & 27 \\
\hline & & & & & $\frac{1}{5}$ \\
\hline \multicolumn{2}{|l|}{$\begin{array}{l}\text { Buccella sp. } \\
\text { Bulimina alazanensis }\end{array}$} & & + & & \\
\hline \multirow{2}{*}{\multicolumn{2}{|c|}{$\begin{array}{l}\text { Bulimina chirana } \\
\text { Bulimina perviana }\end{array}$}} & 3 & 20 & 1 & 8 \\
\hline & & & & & 1 \\
\hline \multicolumn{2}{|l|}{$\begin{array}{l}\text { Bulimina stalacta } \\
\text { Buliminella chirana }\end{array}$} & & + & & \\
\hline \multicolumn{2}{|l|}{$\begin{array}{l}\text { Buliminella chirana } \\
\text { Buliminella penviana }\end{array}$} & 2 & & & \\
\hline \multirow{2}{*}{\multicolumn{2}{|c|}{$\begin{array}{l}\text { Buliminellita minifica } \\
\text { Cibicides sp. }\end{array}$}} & & & & 1 \\
\hline & & & & & 2 \\
\hline \multicolumn{2}{|l|}{$\begin{array}{l}\text { Cibicidooides martinezensis } \\
\text { Cibicidoides perlucidus }\end{array}$} & & + & & \\
\hline \multicolumn{2}{|c|}{ Cibicidoides perlucidus } & & 1 & & \\
\hline \multicolumn{2}{|l|}{$\begin{array}{l}\text { Cibicidoides } \mathrm{spp} . \\
\text { Cyclammina simiensis }\end{array}$} & & 4 & 30 & \\
\hline \multicolumn{2}{|l|}{$\begin{array}{l}\text { Dorothia asiphonia } \\
\text { Don }\end{array}$} & & & 30 & $\begin{array}{l}6 \\
1\end{array}$ \\
\hline \multirow{2}{*}{\multicolumn{2}{|c|}{$\begin{array}{l}\text { Eponides sp. (small) } \\
\text { Fursenkoina nuda (of Hofk }\end{array}$}} & & 19 & 2 & 7 \\
\hline & & 4 & & 2 & + \\
\hline \multicolumn{2}{|l|}{$\begin{array}{l}\text { Globobulimina diversa } \\
\text { Globocassidulina globosa }\end{array}$} & & 1 & 5 & 1 \\
\hline \multicolumn{2}{|c|}{$\begin{array}{l}\text { Globocassidulina globosa } \\
\text { Globocassidulina subglobosa }\end{array}$} & & 10 & 2 & 18 \\
\hline \multicolumn{2}{|c|}{$\begin{array}{l}\text { Globocassidulina subglobosa } \\
\text { Globocassidulina sublaevigata }\end{array}$} & & + & 2 & 1 \\
\hline \multicolumn{2}{|c|}{ Gyroidina perampla } & & + & & \\
\hline \multicolumn{2}{|l|}{$\begin{array}{l}\text { Gyroidinasp. } \\
\text { Hansenisca multilocula }\end{array}$} & & & 7 & 1 \\
\hline \multirow{2}{*}{\multicolumn{2}{|c|}{$\begin{array}{l}\text { Hansenisca soldanii } \\
\text { Haplophragmoides } \mathrm{sp} .\end{array}$}} & & & & \\
\hline & \multirow{2}{*}{$\begin{array}{l}\text { Nodogenerina sp. } \\
\text { Nodosaria longiscata }\end{array}$} & 7 & & & 5 \\
\hline $\begin{array}{l}\text { Nodogenerna sp. } \\
\text { Nodosaria longiscata }\end{array}$ & & & $\frac{1}{5}$ & 8 & \\
\hline Nonionella cf. ecuadora & & 3 & & & \\
\hline Oridorsalis umbonatus & & & 5 & ${ }_{3}^{4}$ & 2 \\
\hline $\begin{array}{l}\text { Plectofrondicularia vaug } \\
\text { Plectofrondicularia spp. }\end{array}$ & & & 1 & & \\
\hline $\begin{array}{l}\text { Quinqueloculina sp. } \\
\text { Spirolocammina tenuis }\end{array}$ & & & & $\begin{array}{l}1 \\
1\end{array}$ & \\
\hline Stichocassidulina thalme & mni & 53 & & 4 & 2 \\
\hline $\begin{array}{l}\text { Stilostomella sp. } \\
\text { Triloculina sp. }\end{array}$ & & & 2 & & 1 \\
\hline Uvigerina ecuadorensis & & & 2 & 1 & 2 \\
\hline $\begin{array}{l}\text { Uvigerina penuviana } \\
\text { Valvulineria peruviana }\end{array}$ & & 3 & $+_{2}^{+}$ & & \\
\hline $\begin{array}{l}\text { unilocular spp. } \\
\text { ungula }\end{array}$ & & & & 2 & \\
\hline Count & & 101 & 105 & 101 & 111 \\
\hline Planktonic/Benthic Ratic & $\times 100$ & 3 & 13 & 36 & 21 \\
\hline
\end{tabular}

${ }^{1}$ Counts less than 100: 45X-CC (Cyclammina simiensis only). 
Table 9. Percentage of species representation, Hole 685A (5071 m).

\begin{tabular}{|c|c|c|c|c|c|c|c|c|c|c|c|c|}
\hline \multicolumn{12}{|l|}{ Age } & \multirow{2}{*}{$\begin{array}{l}\text { late } \\
\text { Mio } \\
0 \\
\dot{\infty} \\
\tilde{j} \\
\end{array}$} \\
\hline Depth (mbsf) & लें & ֻู & $\stackrel{+}{\operatorname{m}}$ & $\dddot{2}$ & $\stackrel{\infty}{\infty}$ & $\stackrel{\circ}{\varrho}$ & $\overrightarrow{3}$ & ָับ & 象 & $\stackrel{3}{\circ}$ & $\stackrel{3}{2}$ & \\
\hline $\begin{array}{cc}\begin{array}{c}\text { Hole 685A } \\
(5071 \mathrm{~m})\end{array} & \begin{array}{c}\text { Core }^{1,2} \\
\text { Section } \\
\text { Interval } \\
(\mathrm{cm})\end{array} \\
\text { Species } & \end{array}$ & $\underset{+}{\dot{4}}$ & 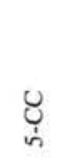 & 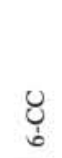 & $\underset{\infty}{\substack{0 \\
\infty}}$ & $\begin{array}{l}\text { نِ } \\
\text { ó }\end{array}$ & $\begin{array}{l}\text { U } \\
\text { ป }\end{array}$ & $\begin{array}{l}\text { U্ } \\
\dot{I}\end{array}$ & 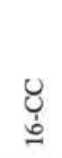 & $\begin{array}{l}\text { Uִ } \\
\stackrel{\infty}{ }\end{array}$ & $\begin{array}{l}\text { Ů } \\
\text { வ }\end{array}$ & $\frac{\text { U্ }}{\frac{1}{N}}$ & $\begin{array}{l}\text { U্口 } \\
\text { D } \\
\text { లn }\end{array}$ \\
\hline $\begin{array}{l}\text { Alexanderina viejoensis } \\
\text { Astrononion schwageri }\end{array}$ & + & & & + & & 1 & 1 & 1 & & & & \\
\hline Bolivina costata & 73 & 10 & 57 & 88 & 90 & 70 & 73 & 83 & 68 & 94 & 52 & \\
\hline $\begin{array}{l}\text { Bolivinita minuta } \\
\text { Brizalina spissa }\end{array}$ & + & & & $\begin{array}{r}1 \\
+\end{array}$ & & + & & & & & + & \\
\hline Bulimina alazanensis & + & & & + & & & & & & & & \\
\hline Bulimina exilis tenuata & 5 & & & + & 1 & & 2 & + & 1 & & 1 & \\
\hline $\begin{array}{l}\text { Bulimina subacuminata } \\
\text { Cassideling complanata }\end{array}$ & + & & & & & & & & & & & \\
\hline Cassidelina complanata & 1 & 6 & & & 1 & + & + & 1 & 2 & & 1 & \\
\hline Cassidulina cushmani & 11 & & & 1 & & & + & & & & 1 & \\
\hline $\begin{array}{l}\text { Cassidulina neocarinata } \\
\end{array}$ & + & & & & & & & & & & & \\
\hline $\begin{array}{l}\text { Cribromiliolinella subvalvularis } \\
\text { Ehrenbergina trigona }\end{array}$ & & & 3 & & & & 1 & & & & & \\
\hline Eilohedra levicula & 2 & 67 & 12 & 3 & 3 & 14 & 5 & 1 & & & 20 & \\
\hline Epistominella smithi & 3 & & & & & & & & & & & \\
\hline $\begin{array}{l}\text { Fontbotia wuellerstorfi } \\
\text { Globobulimina affinis }\end{array}$ & & & & & & & $\begin{array}{l}t \\
+\end{array}$ & 1 & & & 1 & \\
\hline Globocassidulina depressa & & & & 2 & 2 & 11 & 5 & 7 & 13 & 2 & 7 & \\
\hline Gyroidina lamarckiana & & & & 1 & & & 3 & 1 & & & + & \\
\hline Melonis affinis & + & & & + & & 1 & 2 & 2 & 3 & & 6 & 4 \\
\hline Melonis pompilioides & + & & & & & 1 & 2 & 1 & 7 & 2 & 4 & \\
\hline Nonionella auris & + & & & & & & & & & & & \\
\hline Oridorsalis umbonatus & & 6 & & + & & & & & & & & \\
\hline $\begin{array}{l}\text { Pseudoparrella sandiegoensis } \\
\text { Pullenia bulloides }\end{array}$ & + & & & $\begin{array}{l}1 \\
1\end{array}$ & & 1 & 1 & + & & & & + \\
\hline Pullenia quinqueloba & & 1 & 13 & & 1 & $x^{2}$ & $x^{2}$ & & 4 & & + & 4 \\
\hline Pyrgo murrhyna & & 9 & 2 & & & & + & & & & & \\
\hline $\begin{array}{l}\text { Pyrgo spp. } \\
\text { Quinqueloculina spp. } \\
\text { Sigmoilina edwardsi }\end{array}$ & + & & 6 & + & + & 1 & & & $\begin{array}{l}1 \\
1\end{array}$ & & + & $\begin{array}{l}1 \\
1\end{array}$ \\
\hline Sphaeroidina bulloides & & & & & & & + & + & & & & 1 \\
\hline $\begin{array}{l}\text { Takayanagia delicata } \\
\text { Triloculina sp. }\end{array}$ & & & & + & 1 & & & & + & & & \\
\hline Uvigerina auberiana & & & & 2 & 1 & & & & + & & + & 1 \\
\hline Uvigerina peregrina & 1 & & & & & & & & & & & \\
\hline Uvigerina senticosa & 1 & & & & & + & 4 & 1 & & & 5 & \\
\hline $\begin{array}{l}\text { unilocular spp. } \\
\text { Alabamina polita }\end{array}$ & + & + & 7 & + & + & & 1 & 1 & & 2 & 1 & $\begin{array}{l}3 \\
2\end{array}$ \\
\hline Bolivina vaughani & & & & & & & & & & & & 50 \\
\hline Bolivinellina cuneata & & & & & & & & & & & & 2 \\
\hline $\begin{array}{l}\text { Bolivinita aff. minuta } \\
\text { Buliminella curta }\end{array}$ & & & & & & & & & & & & + \\
\hline $\begin{array}{l}\text { Buliminella curta } \\
\text { Fursenkoina sp. }\end{array}$ & & & & & & & & & & & & 1 \\
\hline Globocassidulina sp. & & & & & & & & & & & & 2 \\
\hline Gyroidina turgida & & & & & & & & & & & & 22 \\
\hline Gyroidina sp. & & & & & & & & & & & & + \\
\hline Laticarinina pauperata & & & & & & & & & & & & 1 \\
\hline $\begin{array}{l}\text { Nodosaria consobrina } \\
\text { Pleurostomella sp. }\end{array}$ & & & & & & & & & & & & $+^{3}$ \\
\hline Count & 957 & 171 & 128 & 434 & 205 & 216 & 833 & 140 & 100 & 100 & 197 & 169 \\
\hline Planktonic/Benthic Ratio $\times 100$ & 1 & 11 & 134 & $<1$ & 6 & 19 & 30 & 1 & 711 & 100 & 0 & 11 \\
\hline
\end{tabular}

${ }^{1}$ Barren of foraminifers: 20X-CC; 27X-CC; 28X-CC; 29X-CC; 30X-CC; 31X-CC; 32X-CC; 33X-CC; 34X-CC; 35X-CC; 36X-CC;

$37 \mathrm{X}-\mathrm{CC} ; 39 \mathrm{X}-\mathrm{CC} ; 40 \mathrm{X}-\mathrm{CC} ; 41 \mathrm{X}-\mathrm{CC} ; 42 \mathrm{X}-\mathrm{CC} ; 43 \mathrm{X}-\mathrm{CC} ; 45 \mathrm{X}-\mathrm{CC} ; 46 \mathrm{X}-\mathrm{CC} ; 47 \mathrm{X}-\mathrm{CC} ; 48 \mathrm{X}-\mathrm{CC} ; 49 \mathrm{X}-\mathrm{CC}$.
${ }^{2}$ Counts less than 100 : $1 \mathrm{H}-\mathrm{CC} ; 2 \mathrm{H}-\mathrm{CC} ; 3 \mathrm{H}-\mathrm{CC} ; 23 \mathrm{X}-\mathrm{CC} ; 25 \mathrm{X}-\mathrm{CC} ; 44 \mathrm{X}-\mathrm{CC} ; 50 \mathrm{X}-\mathrm{CC} ; 51 \mathrm{X}-\mathrm{CC}$. 
Table 10. Species abundance Holes 688A and 688E (3820 m).

\begin{tabular}{|c|c|c|c|c|c|c|c|c|c|}
\hline \multirow{2}{*}{\multicolumn{2}{|c|}{$\begin{array}{r}\text { Age } \\
\text { Depth (mbsf) }\end{array}$}} & \multicolumn{8}{|c|}{ Quaternary } \\
\hline & & $\ddot{\infty}$ & $\stackrel{9}{=}$ & 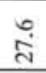 & ڤें & fं & กั & $\stackrel{\overbrace{}}{\check{g}}$ & $\frac{\sim}{\Delta}$ \\
\hline \multicolumn{2}{|c|}{$\begin{array}{cc}\begin{array}{c}\text { Hole } 688 \mathrm{~A} \\
(3820 \mathrm{~m})\end{array} & \begin{array}{c}\text { Section } \\
\text { Interval } \\
(\mathrm{cm})\end{array} \\
\text { Species } & \end{array}$} & $\begin{array}{l}\text { Ů } \\
\stackrel{1}{ \pm}\end{array}$ & 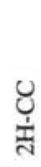 & $\frac{\dot{y}}{\dot{y}}$ & Ư & 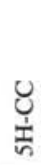 & $\frac{0}{0}$ & $\begin{array}{l}\dot{8} \\
\dot{x} \\
\stackrel{2}{\Omega}\end{array}$ & 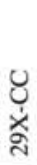 \\
\hline \multicolumn{2}{|c|}{ Astrononion schwageri } & & & C & & A & & & \\
\hline \multicolumn{2}{|c|}{ Cassidelina complanata } & & F & $\mathrm{F}$ & & & $\mathrm{C}$ & & \\
\hline \multicolumn{2}{|c|}{ Cibicidoides cicatricosus } & & & & $\mathrm{R}$ & & & & \\
\hline \multicolumn{2}{|c|}{ Cibicidoides mundula } & $\mathrm{R}$ & & & & & & & \\
\hline \multicolumn{2}{|c|}{ Ehrenbergina trigona } & & $\mathbf{R}$ & & $\mathrm{R}$ & & & & \\
\hline \multicolumn{2}{|c|}{ Eilohedra levicula } & $\mathrm{F}$ & & & $\mathrm{F}$ & $\mathrm{C}$ & $\mathrm{C}$ & F & C \\
\hline \multicolumn{2}{|c|}{ Fontbotia wuellerstorfi } & & & & $\mathrm{R}$ & & & & \\
\hline \multicolumn{2}{|c|}{ Hansenisca zealandica } & $\mathrm{R}$ & & $\mathrm{F}$ & $\mathrm{F}$ & & & & \\
\hline \multicolumn{2}{|c|}{ Hoeglundina elegans } & & & C & F & A & & $\mathbf{R}$ & \\
\hline \multicolumn{2}{|c|}{ Martinottiella communis } & & & R & $\mathrm{R}$ & $\mathrm{R}$ & & & \\
\hline \multicolumn{2}{|c|}{ Melonis affinis } & C & $\mathrm{C}$ & $\mathrm{C}$ & $\mathrm{C}$ & A & $\mathrm{C}$ & A & $\mathrm{C}$ \\
\hline \multicolumn{2}{|c|}{ Melonis pompilioides } & C & A & & A & A & $\mathrm{C}$ & $\mathrm{F}$ & \\
\hline \multicolumn{2}{|l|}{ Karreriella bradyi } & $\mathrm{R}$ & & & & & & & \\
\hline \multicolumn{2}{|c|}{ Oridorsalis umbonatus } & $\mathrm{C}$ & & $\mathrm{F}$ & $\mathrm{F}$ & $\mathrm{F}$ & & $\mathrm{C}$ & \\
\hline \multicolumn{2}{|c|}{ Pseudoparrella exigua } & $\mathrm{F}$ & & C & C & A & & & \\
\hline \multicolumn{2}{|c|}{ Pullenia bulloides } & $\mathrm{C}$ & $\mathrm{C}$ & C & $\mathrm{F}$ & $\mathrm{F}$ & & F & \\
\hline \multicolumn{2}{|c|}{ Pyrgo murrhyna } & & & $\mathrm{R}$ & & F & & & \\
\hline \multicolumn{2}{|c|}{$\begin{array}{l}\text { Pyrgo sp. } \\
\text { Uvigerina auberiana }\end{array}$} & & $\mathrm{R}$ & & & & & $\mathrm{F}$ & \\
\hline \multicolumn{2}{|l|}{ Uvigerina senticosa } & $\mathrm{C}$ & A & A & A & A & C & A & A \\
\hline \multicolumn{2}{|l|}{ unilocular spp. } & C & & F & $\mathrm{F}$ & & & & $\mathrm{F}$ \\
\hline \multicolumn{2}{|c|}{ Bolivina costata } & $\mathrm{C}$ & $\mathrm{C}$ & C & $\mathrm{F}$ & $\mathrm{C}$ & A & $\mathrm{C}$ & A \\
\hline \multicolumn{2}{|c|}{ Other transported species } & & $\mathrm{C}$ & & & & C & $\mathrm{R}$ & \\
\hline
\end{tabular}

${ }_{1}^{1}$ Barren of foraminifers: 23X-CC, 26X-CC, 31X-CC, 35X-CC, 36X-CC, 37X-CC.

${ }^{2}$ Less than 100 specimens/spl: 14X-CC, $15 \mathrm{X}-\mathrm{CC}, 16 \mathrm{X}-\mathrm{CC}, 17 \mathrm{X}-\mathrm{CC}, 18 \mathrm{X}-\mathrm{CC}$ $20 \mathrm{X}-\mathrm{CC}, 21 \mathrm{X}-\mathrm{CC}, 22 \mathrm{X}-\mathrm{CC}, 25 \mathrm{X}-\mathrm{CC}, 32 \mathrm{X}-\mathrm{CC}$, $33 \mathrm{X}-\mathrm{CC}, 34 \mathrm{X}-\mathrm{CC}$.
Table 10 (continued).

\begin{tabular}{|c|c|c|c|c|}
\hline \multirow[b]{3}{*}{$\begin{array}{l}\text { Hole } 688 \mathrm{E} \\
(3826 \mathrm{~m})\end{array}$} & \multirow{2}{*}{$\begin{array}{c}\text { Age } \\
\text { th (mbsf) }\end{array}$} & $\begin{array}{l}\mathrm{m} . \\
\text { Mio. }\end{array}$ & \multicolumn{2}{|c|}{ e. Mio. } \\
\hline & & 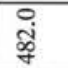 & $\begin{array}{l}\infty \\
\ddot{\sim} \\
\dot{v}\end{array}$ & นิ \\
\hline & $\begin{array}{l}\text { Core } \\
\text { Section } \\
\text { Interval } \\
(\mathrm{cm})\end{array}$ & $\begin{array}{l}\text { ठ্் } \\
\text { है }\end{array}$ & $\begin{array}{l}\text { U্் } \\
\dot{\tilde{n}}\end{array}$ & $\begin{array}{l}\text { U্ } \\
\text { ָै }\end{array}$ \\
\hline \multirow{5}{*}{\multicolumn{2}{|c|}{$\begin{array}{l}\text { Amphimorphina stainforthi } \\
\text { Brizalina pisciformis } \\
\text { Bulimina alazanensis } \\
\text { Bulimina alligata } \\
\text { Cibicidoides } \text { cf. pseudoungerianus }\end{array}$}} & $\mathrm{C}$ & $\mathbf{R}$ & \\
\hline & & $\mathrm{R}$ & & $\mathrm{C}$ \\
\hline & & & & C \\
\hline & & A & $\mathbf{R}$ & \\
\hline & & & & $\mathrm{R}$ \\
\hline \multicolumn{2}{|c|}{ Eilohedra levicula } & C & & \\
\hline \multicolumn{2}{|l|}{ Fursenkoina sp. } & $\begin{array}{l}F \\
R\end{array}$ & & \\
\hline \multicolumn{2}{|c|}{$\begin{array}{l}\text { Hanzawaia cf. mantaensis } \\
\text { Heterolepa ? crebbsi }\end{array}$} & $\mathrm{R}$ & $\mathrm{R}$ & $\begin{array}{l}\mathrm{A} \\
\mathrm{R} \\
\mathrm{A}\end{array}$ \\
\hline \multicolumn{2}{|l|}{$\begin{array}{l}\text { Melonis affinis } \\
\text { Melonis pompilioides }\end{array}$} & C & $\mathbf{R}$ & $\mathrm{F}$ \\
\hline \multicolumn{2}{|l|}{$\begin{array}{l}\text { Melonis pompilioides } \\
\text { Nodosaria longiscata }\end{array}$} & C & $\mathbf{R}$ & $\mathrm{A}$ \\
\hline \multicolumn{2}{|l|}{ Oridorsalis umbonatus } & & $\mathrm{R}$ & C \\
\hline \multicolumn{2}{|c|}{$\begin{array}{l}\text { Osangularia interrupta } \\
\text { Planulina } \mathrm{sp} .\end{array}$} & F & & \\
\hline \multicolumn{2}{|c|}{$\begin{array}{l}\text { Planulina sp. } \\
\text { Plectofrondicularia advena }\end{array}$} & $F$ & & $\mathrm{~F}$ \\
\hline \multicolumn{2}{|c|}{$\begin{array}{l}\text { Plectofrondicularia spp. } \\
\text { Plo }\end{array}$} & $\mathrm{F}$ & & $\mathbf{R}$ \\
\hline \multicolumn{2}{|c|}{ Pleurostomella spp. } & F & & \\
\hline \multicolumn{2}{|c|}{ Pullenia bulloides } & F & $\mathbf{R}$ & \\
\hline \multicolumn{2}{|c|}{$\begin{array}{l}\text { Rectuvigerina cf. multicostata } \\
\text { Robulus aff, brevispinosus }\end{array}$} & & & $\begin{array}{l}\mathrm{F} \\
\mathrm{F}\end{array}$ \\
\hline \multirow{2}{*}{\multicolumn{2}{|c|}{$\begin{array}{l}\text { Stilostomella spp. } \\
\text { Uvigering gallowayi }\end{array}$}} & A & $\mathrm{R}$ & $\mathrm{F}$ \\
\hline & & & $\mathrm{R}$ & $\mathrm{R}$ \\
\hline \multicolumn{2}{|l|}{ Uvigerina mantaensis } & & F & A \\
\hline unilocular spp. & & $\mathrm{R}$ & $\mathbf{R}$ & \\
\hline
\end{tabular}

${ }^{1}$ Barren of foraminifers: $1 \mathrm{R}-\mathrm{CC}, 2 \mathrm{R}-\mathrm{CC}, 3 \mathrm{R}-\mathrm{CC}, 4 \mathrm{R}-\mathrm{CC}$, 5R-CC, 6R-CC, 7R-CC, 8R-CC 9R-CC, 10R-CC, 11R-CC, 19RCC, 20R-CC, 26R-CC

${ }^{2}$ Less than 100 specimens/spl: 12R-CC, 13R-CC, 14RCC, 16R-CC, 24R-CC 25R-CC. 
Table 10 (continued).

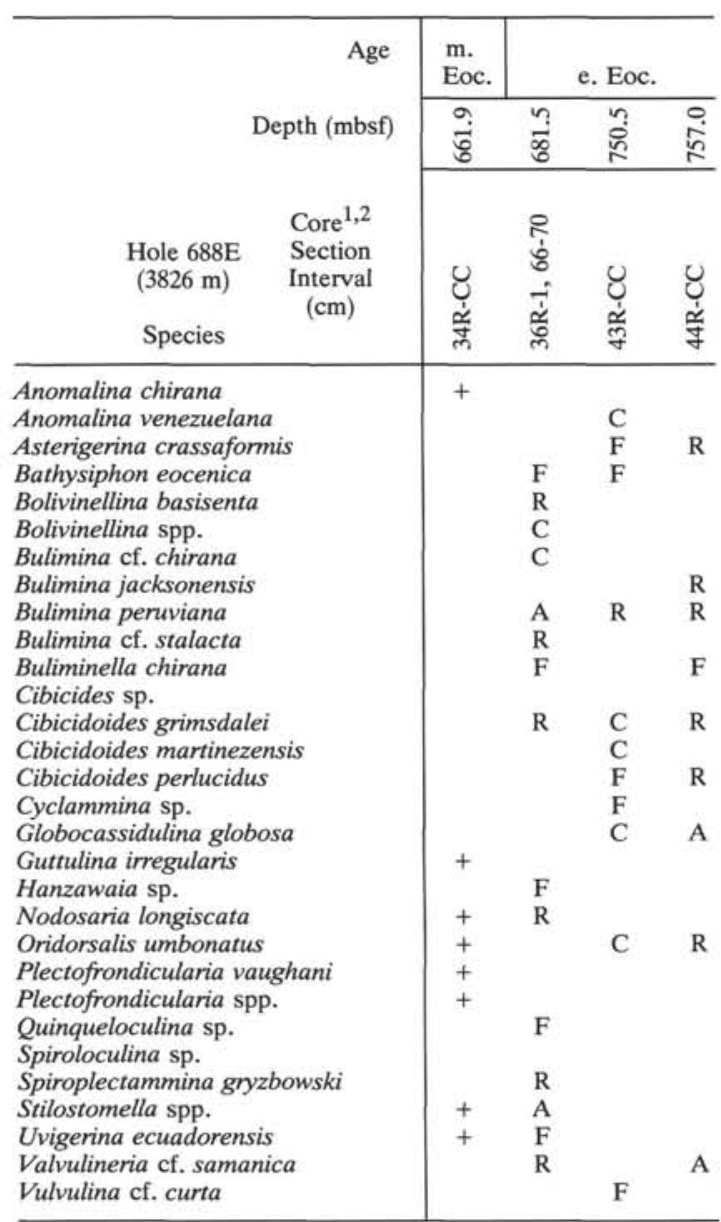

${ }^{1}$ Barren of foraminifers: 29R-CC, 33R-CC, 37R-CC, 40R-CC.

${ }^{2}$ Less than 100 specimens/spl: 27R-CC, 30R-CC, 31R-CC, 32RCC, 35R-CC, 36R-CC, 38R-CC 39R-CC, 41R-CC, 42R-CC, 45R-CC. 


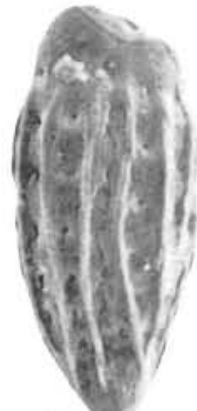

1

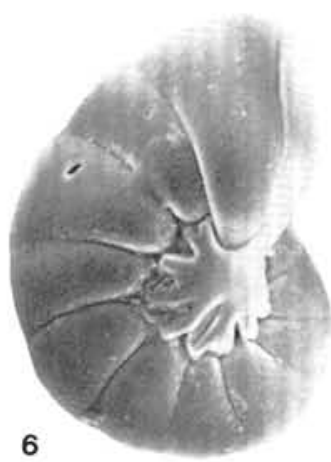

6

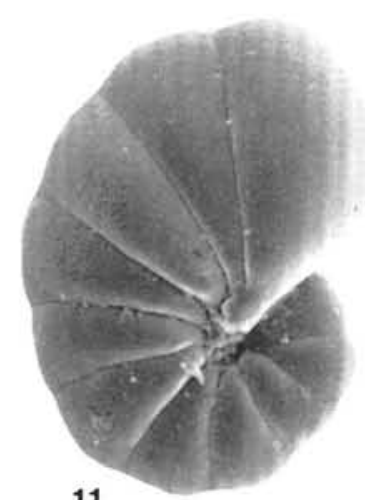

11
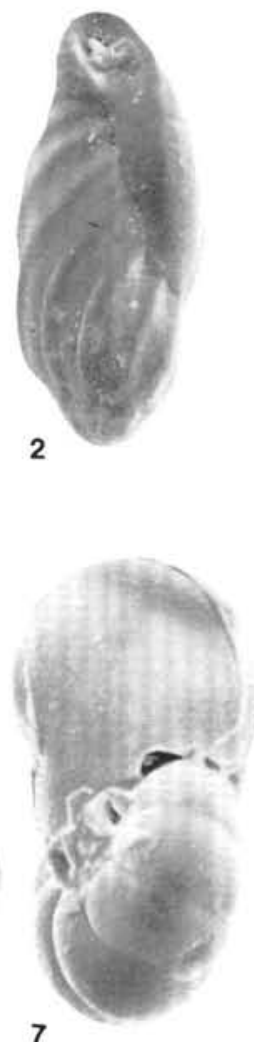

7

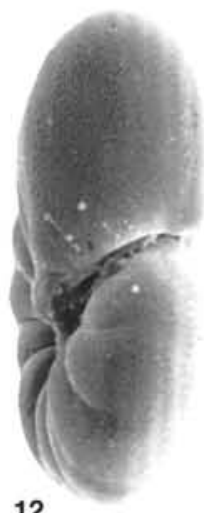

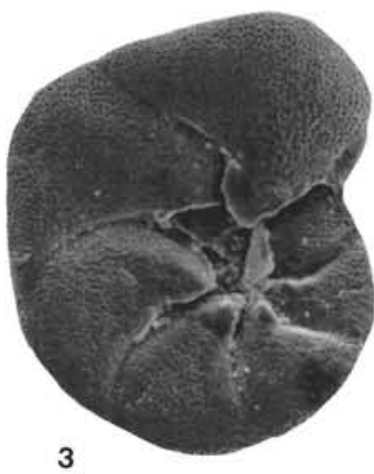
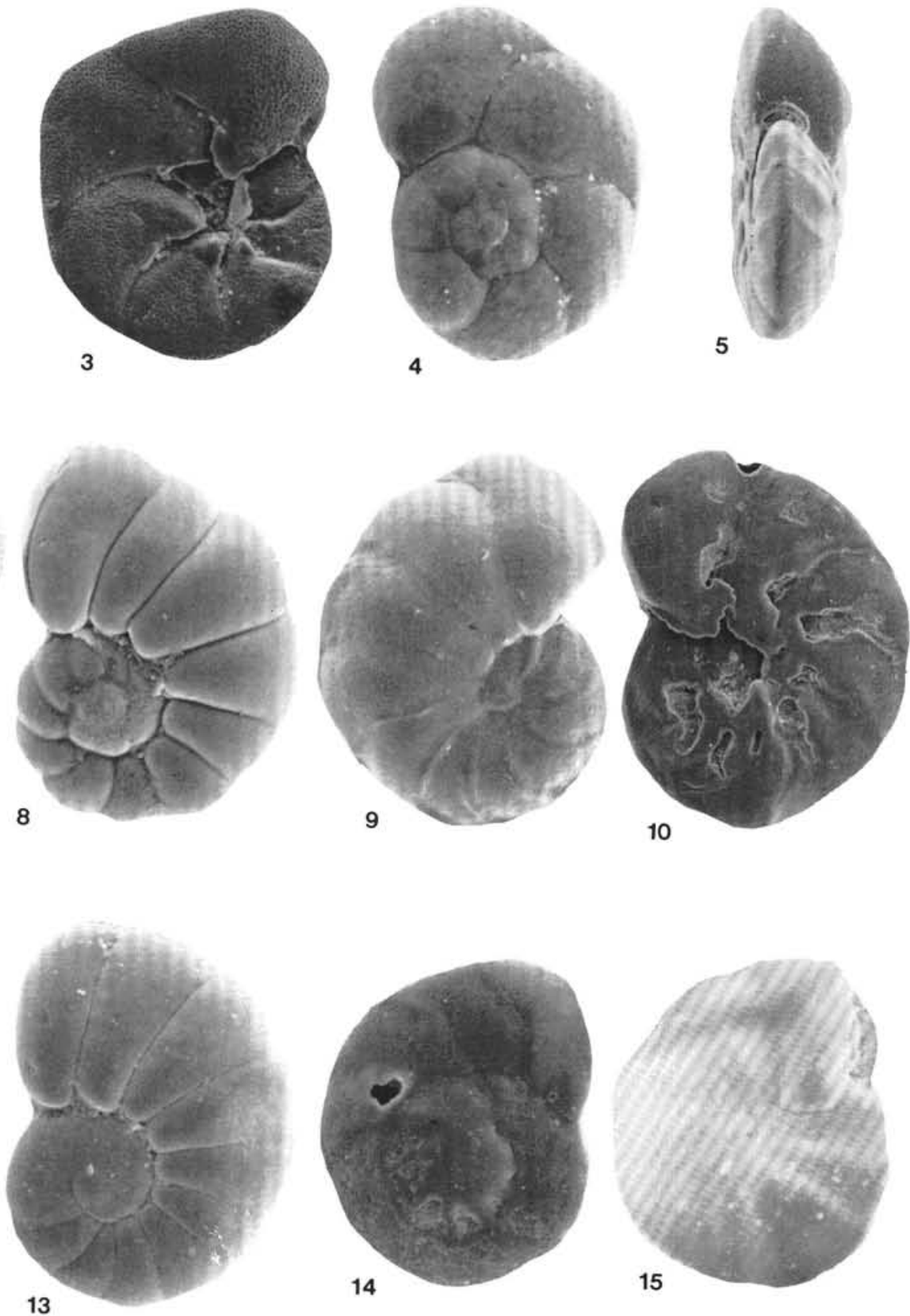

15

Plate 1. Quaternary shelf species. 1. Bolivina costata d'Orbigny, $\times 106$, Sample 112-687A-22X-CC. 2. Buliminella elegantissima limbosa Cushman and McCulloch, $\times 137$, Sample 112-686A-22X-CC. 3-4. Rosalina peruviana d'Orbigny, (3) ventral, $\times 96$, Sample 112-686A-22X-CC, (4) dorsal, $\times 117$, Sample 112-686A-22X-CC. 6-8. Nonionella miocenica Cushman, (6) ventral, $\times 124$, Sample 112-687A-22X-CC, (7) edge, $\times 130$, Sample 112-687A-22X-CC, (8) dorsal, $\times 143$, Sample 112-687A-22X-CC. 5, 9-10. Hanzawaia nitidula (Bandy), (5) edge, $\times 45$, Sample 112-686A-22X-CC, (9) ventral, $\times 46$, Sample 112-686A-22X-CC, (10) dorsal, $\times 57$, Sample 112-686A-22X-CC. 11-13. Nonionella auris (d'Orbigny), (11) ventral, $\times 119$, Sample 112-686A-22X-CC, (12) edge, $\times 124$, Sample 112-686A-22X-CC (13) dorsal, $\times 129$, Sample $112-$ $686 \mathrm{~A}-22 \mathrm{X}-\mathrm{CC}$. 14,15. Alexanderina viejoensis McCulloch, (14) dorsal, $\times 177$, Sample 112-686A-22X-CC, (15) ventral, $\times 198$, Sample 112 686A-22X-CC. 


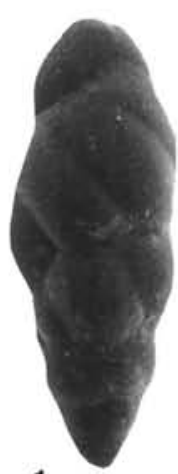

1

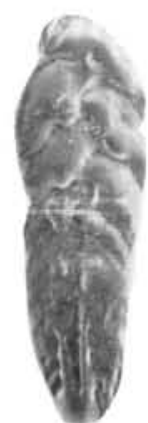

9

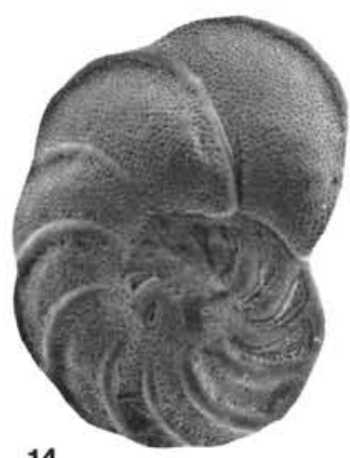

14

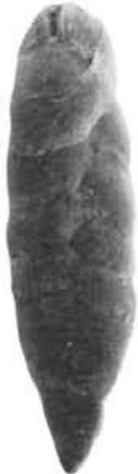

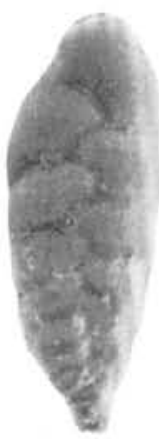

3

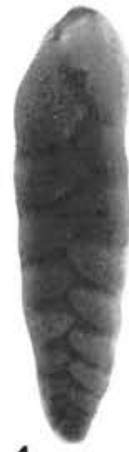

4

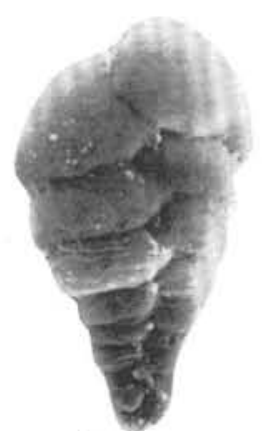

5

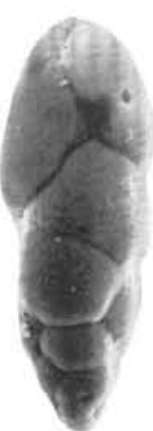

6

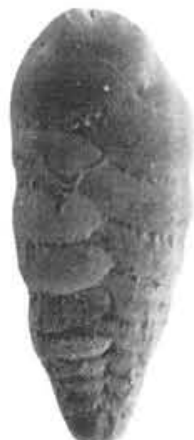

7

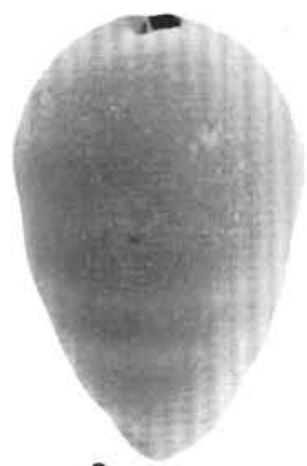

8

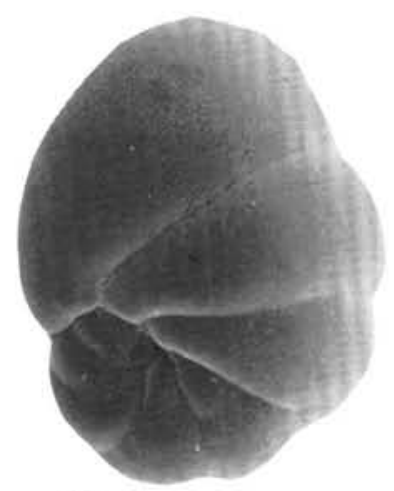

13

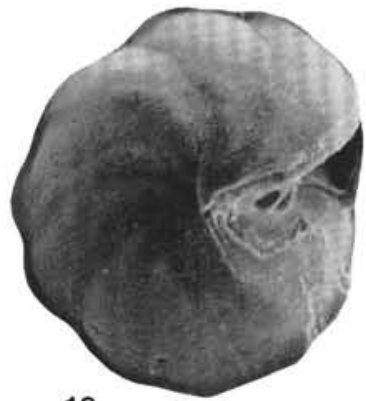

16

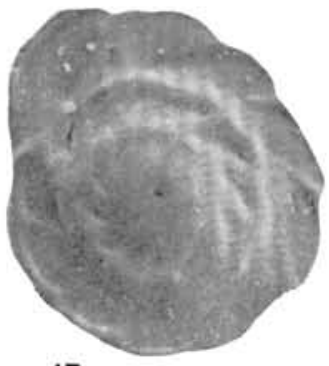

17

Plate 2. Quaternary outer-shelf-upper-bathyal oxygen-minium species. 1. Buliminella subfusiformis Cushman, $\times 54$, Sample 112-187A-15X-CC. 2,3. Bolivinellina humilis (Cushman and McCulloch), (2) $\times 53$, Sample $112-687 \mathrm{~A}-15 \mathrm{X}-\mathrm{CC},(3) \times 81$, Sample $112-680 \mathrm{~A}-3 \mathrm{H}-\mathrm{CC}$. 4. Bolivinellina pacifica (Cushman and McCulloch), $\times 108$, Sample 112-680A-3H-CC. 5. Suggrunda eckisi Natland, $\times 165$, Sample 112-680A-3H-CC. 6. Fursenkoina glabra (Cushman and Wickenden), $\times 148$, Sample 112-680A-3H-CC. 7. Parabolivina peruensis Resig, $\times 35$, Sample 112679B-2H-CC. 8. "Ellipsoglandulina" fragilis Bramlette, $\times 25$, Sample 112-679B-2H-CC. Quaternary upper bathyal current species. 9. Brizalina interjuncta (Cushman), $\times 32$, Sample 112-679B-1H-CC. 10. Angulogerina carinata Cushman, $\times 33$, Sample 112-680A-5H-CC. 11-13. Cancris carmenensis Natland, (11) dorsal, $\times 45$, Sample 112-679B-1H-CC, (12) ventral, $\times 45$, Sample 112-679B-1H-CC, (13) dorsal, $\times 38$, Sample 112-679B-1H-CC. 14,15. Cancris inflatus (d'Orbigny), (14) dorsal, $\times 55$, Sample $112-680 \mathrm{~A}-5 \mathrm{H}-\mathrm{CC}$, (15) ventral, $\times 48$, Sample $112-680 \mathrm{~A}-5 \mathrm{H}-\mathrm{CC}$. 16,17. Epistominella afueraensis McCulloch, (16) ventral, $\times 103$, Sample $112-680 \mathrm{~A}-5 \mathrm{H}-\mathrm{CC}$ (17) dorsal, $\times 88$, Sample $112-680 \mathrm{~A}-5 \mathrm{H}-\mathrm{CC}$. 


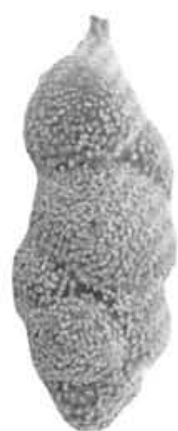

1
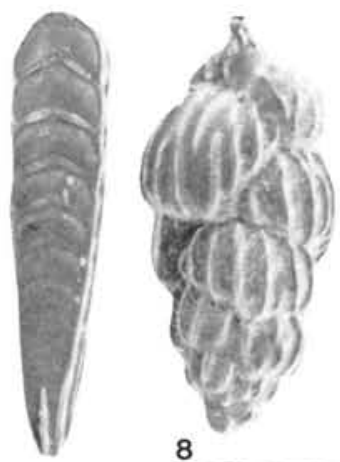

8

7

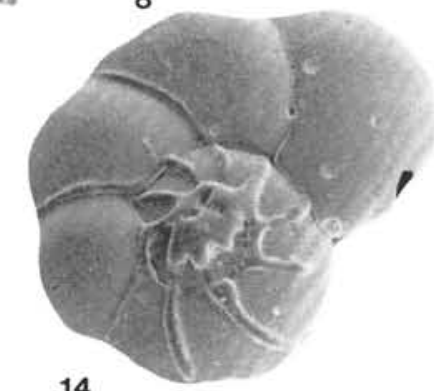

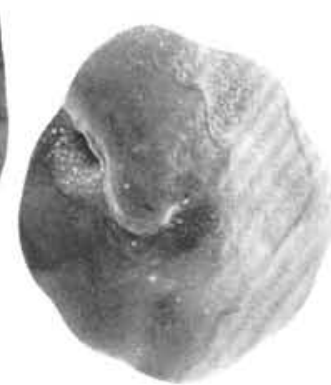

3

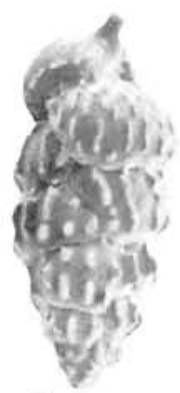

9
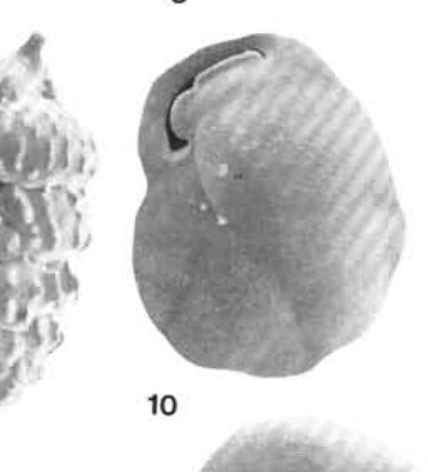

10
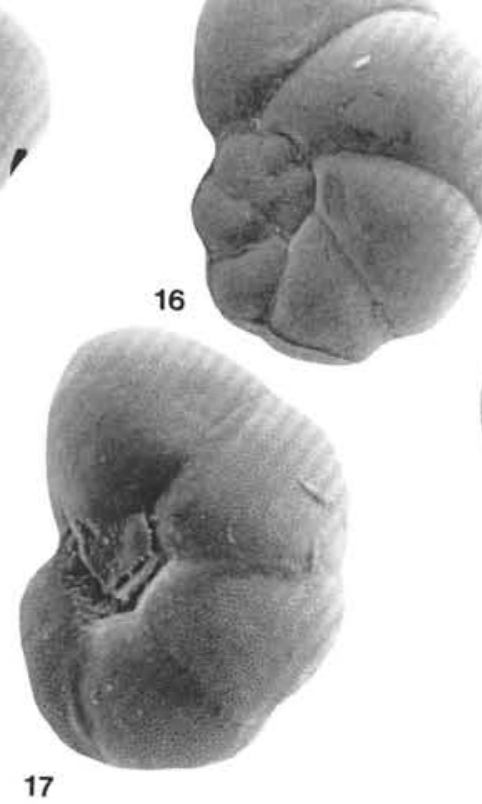

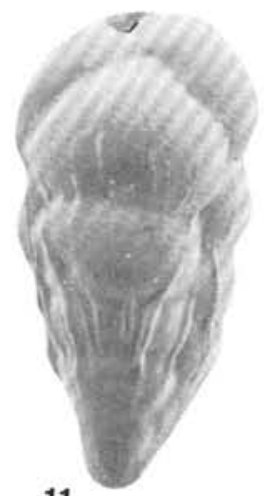

11

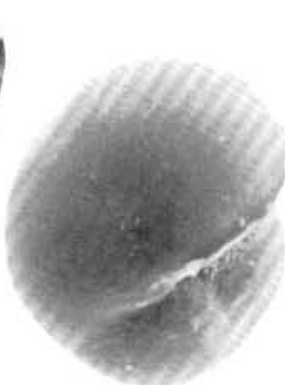

5

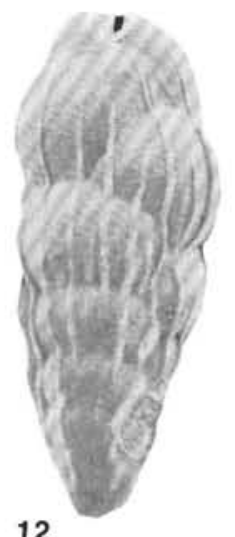

12

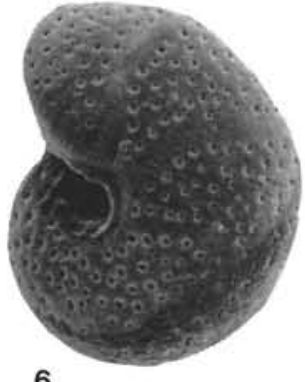

6

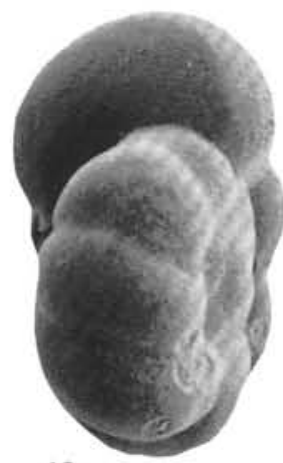

13

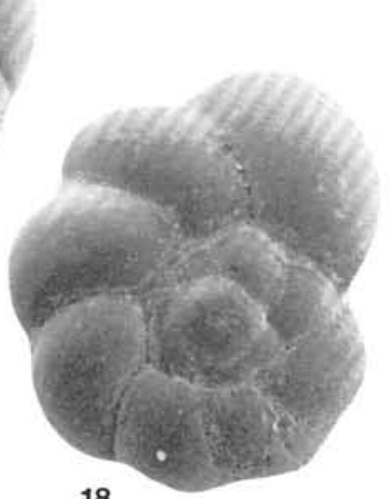

18

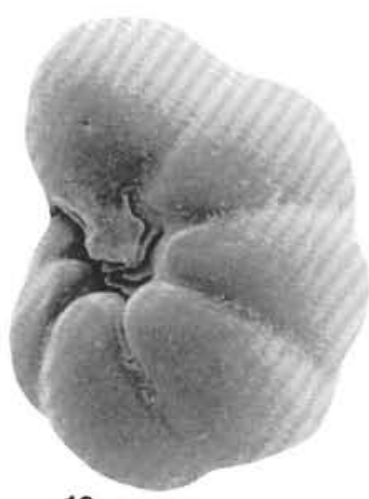

19

$$
17
$$

Plate 3. Quaternary lower bathyal species. 1. Uvigerina senticosa Cushman, $\times 48$, Sample 112-682A-1H-CC. 2. Pseudoparrella exigua (Brady), ventral, $\times 150$, Sample 112-682A-2H-CC. 3. Oridorsalis umbonatus (Reuss), ventral, $\times 80$, Sample 112-682A-1H-CC. 4. Globocassidulina depressa (Asano and Nakamura), $\times 160$, Sample 112-682A-1H-CC. 5. Pullenia bulloides (d'Orbigny), $\times 96$, Sample 112-682A-1H-CC. 6. Melonis pompilioides (Fichtel and Moll), $\times 100$, Sample 112-685A-14X-CC. Pliocene upper-middle bathyal species. 7. Plectofrondicularia californica Cushman and Stewart, $\times 36$, Sample 112-684A-5H-CC. 8,9. Uvigerina peregrina Cushman, $(8) \times 50$, Sample $112-684$ A-5H-CC, $(9) \times 41$, Sample 112-684A-5H-CC. 10. Cassidulina cushmani R.E. and K.C. Stewart, $\times 78$, Sample 112-684A-5H-CC. Late Miocene-early Pliocene outer-shelf species 11. Galliherina $\mathrm{cf}$. delreyensis (Cushman and Galliher), $\times 42$, Sample 112-679B-8H-CC. 12. Galliherina uvigerinaformis (Cushman and Keinpell), $\times 67$, Sample 112-684A-8H-CC. 14,15. Valvulineria cf. compressa Stone, (14) dorsal, $\times 61$, Sample 112-684A-8H-CC, (15) Ventral, $\times 75$, Sample 112-684A-8H-CC. 16,17. Valvulineria $\mathrm{cf}$. depressa Cushman, (16) dorsal, $\times 61$, Sample 112-684A-8H-CC, (17) ventral, $\times 99$, Sample 112-684A-8H-CC. 13, 18,19. Valvulineria californica Cushman, (13) edge, $\times 37$, Sample 112-679B-8H-CC, (18) dorsal, $\times 41$, Sample 112-679B-8H-CC, (19) ventral, ×41, Sample 112-679B-8H-CC. 


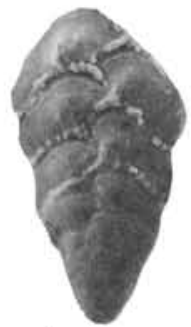

1

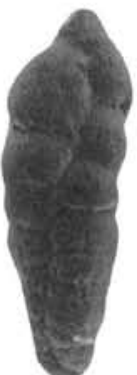

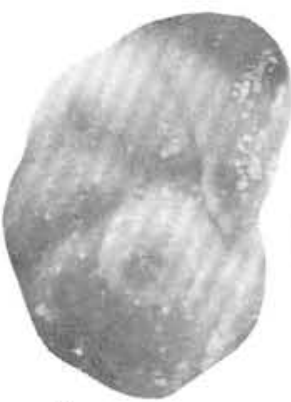

8

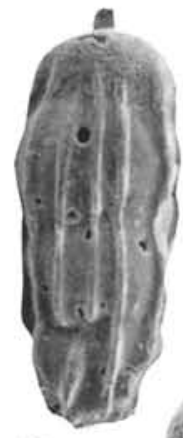

13

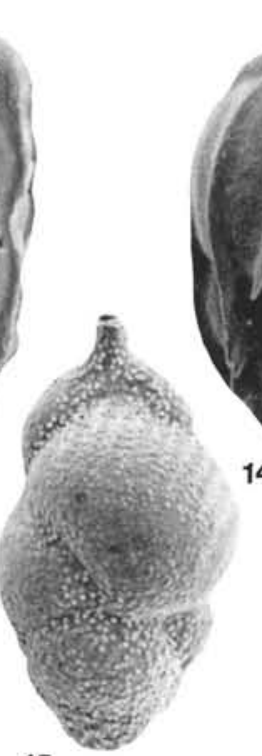

15

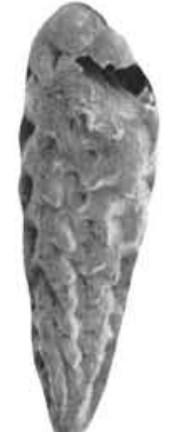

3

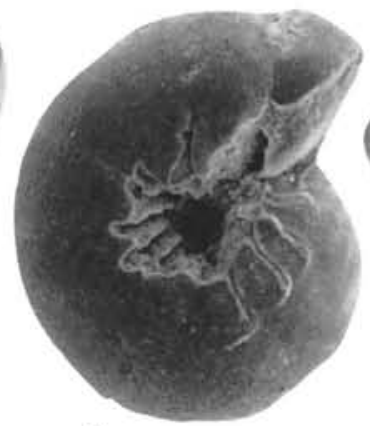

9

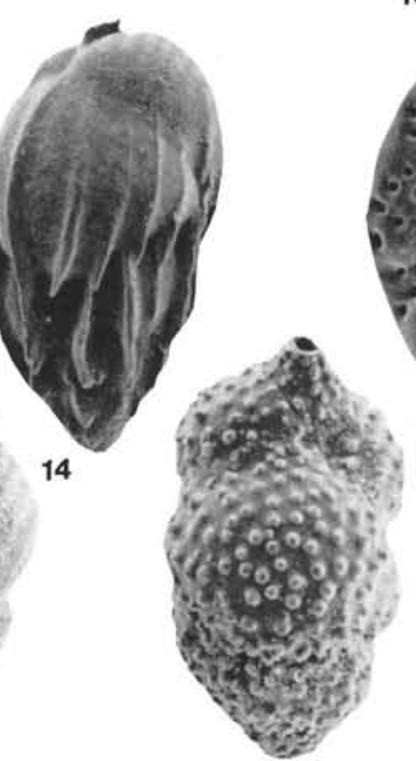

16

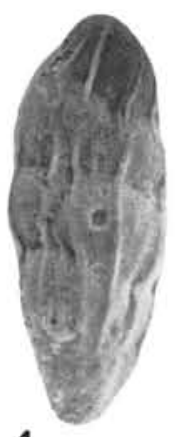

4

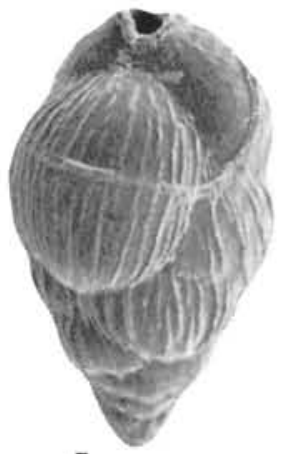

5

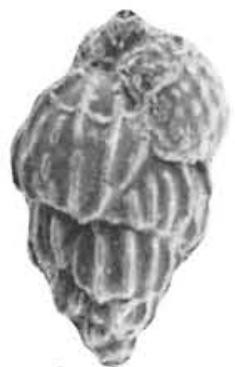

6

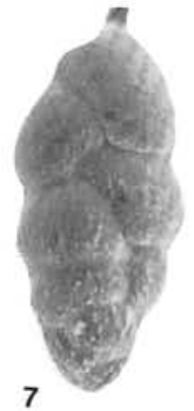

7

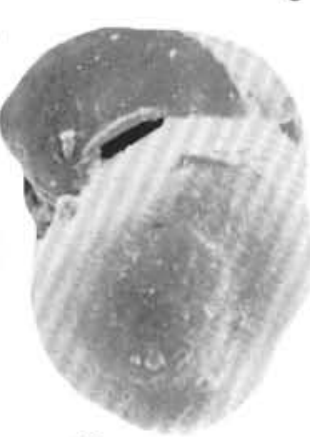

10

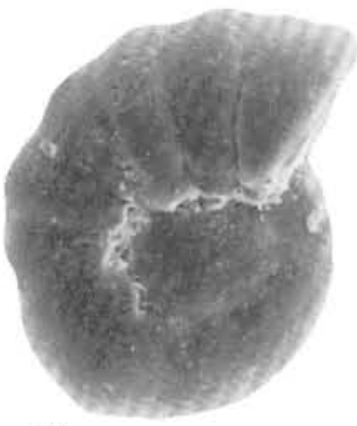

11

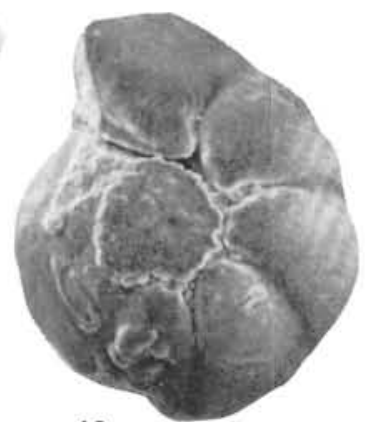

12

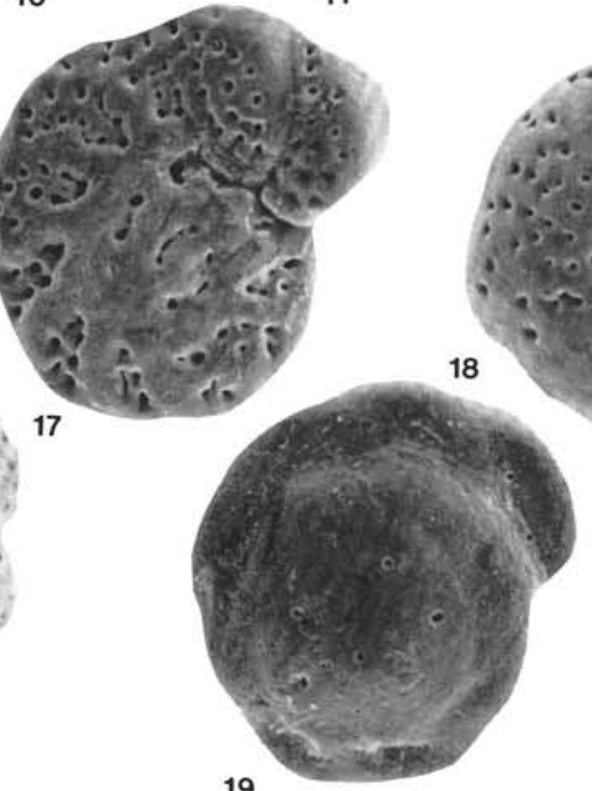

19

20

Plate 4. Late Miocene middle bathyal species. 1. Brizalina girardensis (Rankin), $\times 90$, Sample $112-682 \mathrm{~A}-8 \mathrm{H}-\mathrm{CC}$ (early Pliocene). 2. Bolivina granti Rankin, $\times 50$, Sample 112-682A-15X-CC. 3. Bolivina sinuata Galloway and Wissler, $\times 40$, Sample $112-682$ A-17X-CC. 4. Fursenkoina restinensis (Berry), $\times 100$, Sample 112-682A-15X-CC. 5. Uvigerina marksi Cushman and Stevenson, $\times 41$, Sample $112-682 \mathrm{~A}-15 \mathrm{X}-\mathrm{CC}$. 6. Uvigerina peregrina dirupta Todd, $\times 44$, Sample 112-682A-17X-CC. 7. Uvigerina mantaensis Cushman and Edwards, $\times 55$, Sample 112682A-17X-CC. 8. Ambitropus thalmanni (Stainforth and Stevenson), dorsal, $\times 158$, Sample 112-682A-16X-CC. 9-11. Hansenisca multilocula Coryell and Mossman, (9) ventral $\times 83$, Sample 112-682A-16X-CC, (10) edge, $\times 126$, Sample 112-682A-16X-CC, (11) dorsal, $\times 108$, Sample 112-682A-16X-CC. 12. Rotorbinella garveyensis (Natland), ventral, $\times 117$, Sample 112-682A-16X-CC. Middle Miocene middle bathyal species. 13. Uvigerina gallowayi Cushman, $\times 45$, Sample $112-682 \mathrm{~A}-33 \mathrm{X}-\mathrm{CC}$. 14. Uvigerina gallowayi basicordata Cushman and Renz, $\times 60$, Sample 112-682A-34X-CC. 15. Uvigerina mantaensis Cushman and Edwards, $\times 69$, Sample 112-682A-34X-CC. 16. Uvigerina rustica Cushman and Edwards, $\times 78$, Sample 112-682A-34X-CC. Middle Miocene lower bathyal species. 17,18. Cibicidoides trinitatensis (Nuttall), (17) dorsal, $\times 92$, Sample 112-683A-40X-CC, (18) ventral, $\times 66$, Sample 112-683A-40X-CC. 19,20. Hansenisca zealandica, (Finlay), (19) dorsal, $\times 59$, Sample 112-683A-40X-CC, (20) edge, $\times 66$, Sample 112-683A-40X-CC. 

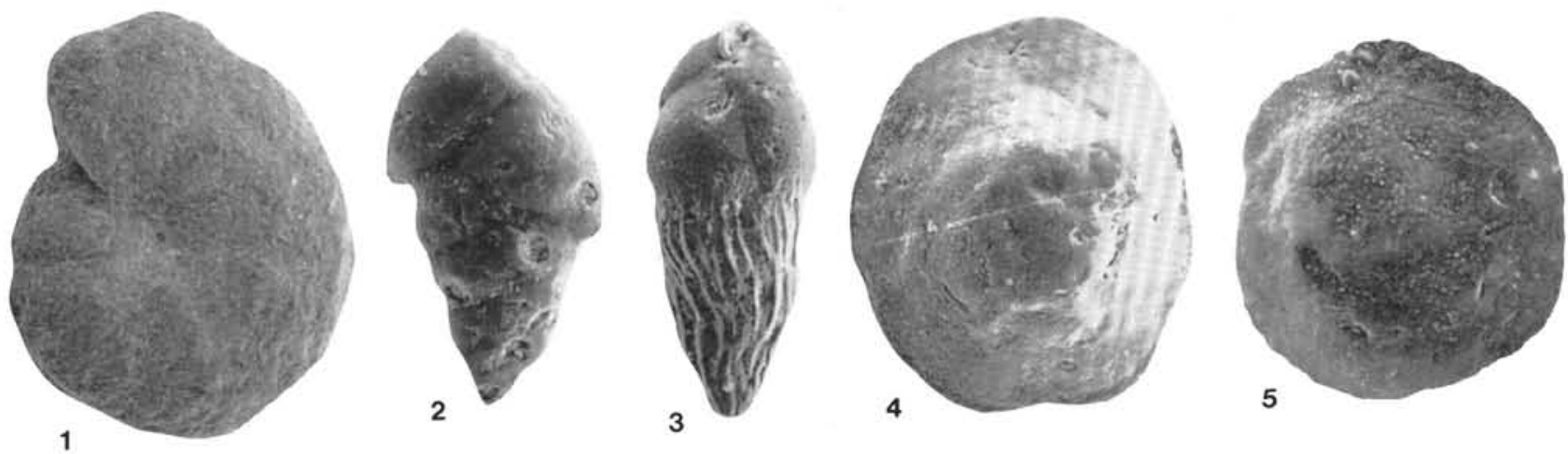

Plate 5. Middle Eocene shelf and upper bathyal species. 1. Cyclammina simiensis Cushman and McMasters, $\times 24$, Sample $112-682 \mathrm{~A}-45 \mathrm{X}-\mathrm{CC}$. 2. Bolivinellina basisenta Cushman and Stone, $\times 158$, Sample 112-682A-46X-CC. 3. Bulimina chirana Cushman and Stone, $\times 98$, Sample 12-682A-46X-CC. 4,5. Asterigerina crassaformis Cushman and Siegfus, (4) dorsal, $\times 119$, Sample 112-682A-46X-CC, (5) ventral, $\times 95$, Sample 112-682A-46X-CC. 